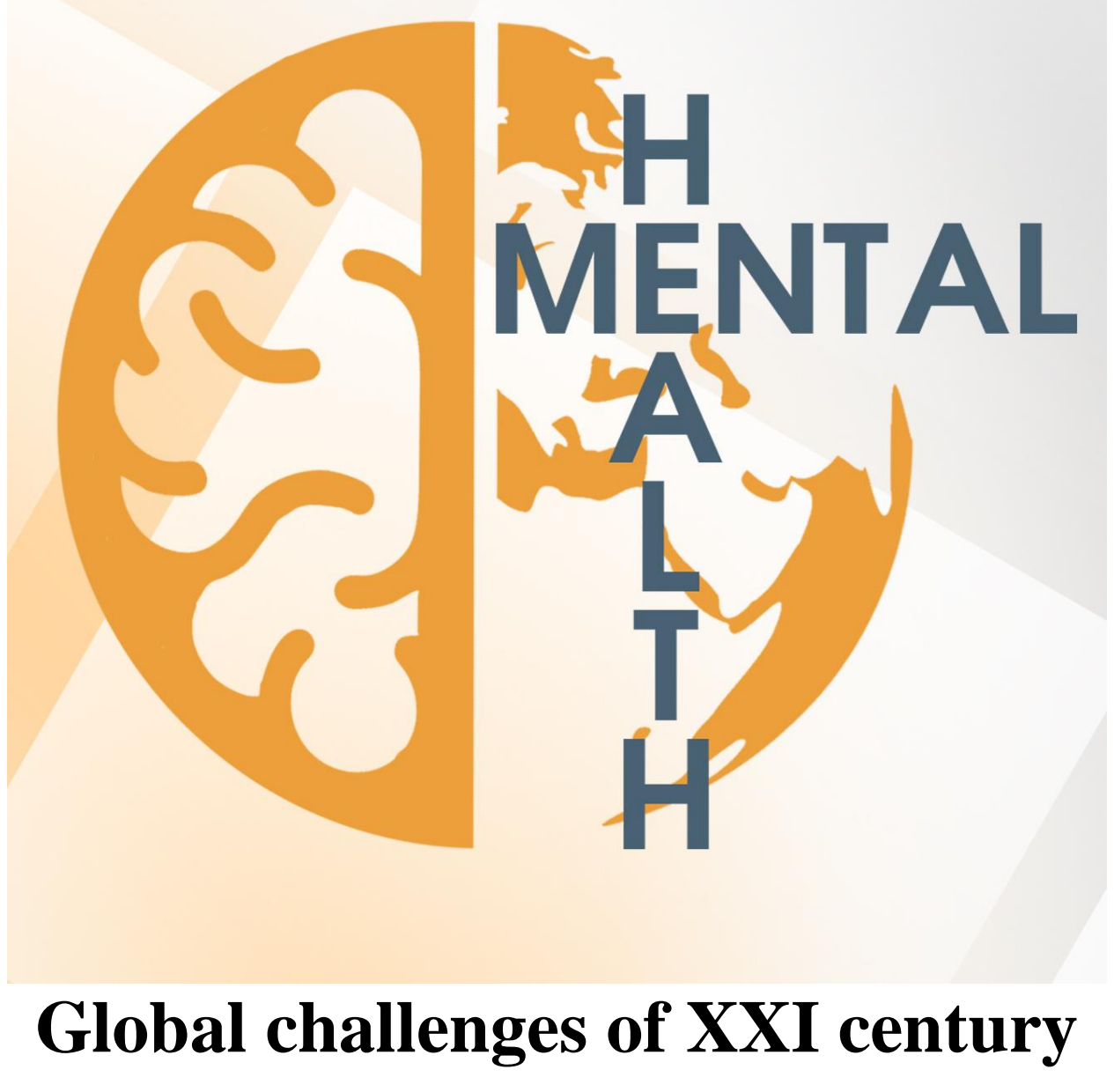

\title{
MHGC PROCEEDINGS
}

How to cite:

Rome 2019

Author (2019). Title of the paper, MHGC Proceedings (pp.). Rome, Italy 


\section{Published from}

the year 2017

\section{Publication frequency}

1 issue/year
Issue status

National/International

\section{Founders}

The MHGC Proceedings was originally founded by NDSAN Network (MFC Coordinator of the NDSAN)

\section{Issue languages \\ Media environment \\ International \\ Abbreviation key title MHGCP}

\section{Target audience}

Scientists/researchers (medical, social, educational fields and etc.), mental health $(\mathrm{MH})$ practitioners, policy-makers, researchers, lawyers.

\section{Major objectives}

- to attract attention of researchers and policy-makers to urgent problems of mental health care (MHC)

- to provide a platform for dissemination of ideas and development of academic and non-academic network of MHC researchers, practitioners and policy-makers

- to promote high quality research most specifically on $\mathrm{MH}$ in developing countries and countries in transition

- to investigate multi-disciplinary, transdisciplinary and multicultural aspects and solutions related to MHC

\section{Field of study and special focus}

Medicine, Social Sciences, Education, Economics, Law, Inter- and Transdisciplinary studies

\section{Topics}

- MHC systems in the context of global social challenges:

- Mental health and migration:

- Mental health in times of military conflicts

- Mental health and community

- Specific issues of MHC: child neuropsychiatry; support for people with disabilities, work with elders related to mental health; MHC in rural areas; addictive behavior

- Higher Education and MHC: Research and Innovations:

\section{How to cite:}

Author (2019). Title of the paper, MHGC Proceedings (pp.). Rome, Italy. 
The MHGC Proceedings contain research papers on multidisciplinary aspects of Mental Health Care system in globally

UDK 159.922.27:316.33(811.111)

DOI: http://doi.org/10.32437/MHGCProceedings.Issue-2019

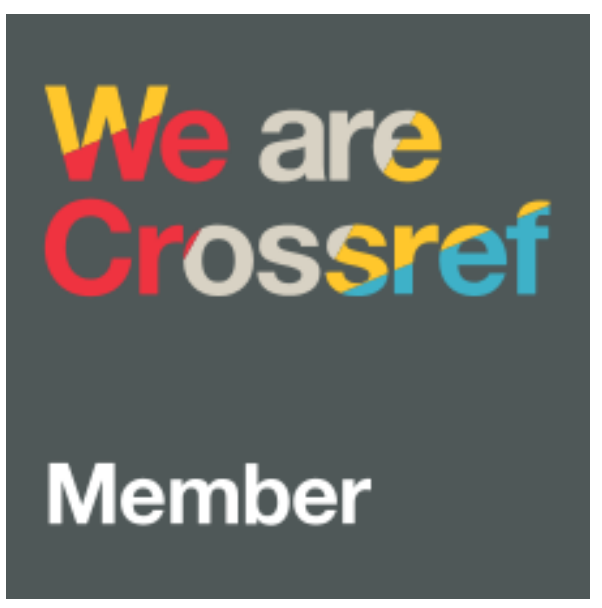

\section{Indexed in CrossRef}

The MHGC Proceedings contain research papers on multidisciplinary aspects of Mental Health Care system in globally.

\section{UDK 59.922.27:316.33(811.111)}




\section{Contents}

Galina Itskovich

D. Kolodych, Kateryna Milutina, Vsevolod Zelenin,Tetiana

Andrushchenko

Olena Koshelieva

Nataliya Lisova

Elena Shopsha, Tatiana Vakulich

Ruslana Bilous

Antonina Kononchuk, Tetyana Svatenkova, Oleksandr Svatenkov, Danylo Kononchuk

Olena Kostyuk, Olena.Boychuk

Evangelos Fradelos

Nadiia Golembievska

Iryna Guzenko

Tetiana Larina

Tezkratt Abdenacer

Viktor Vus

Vira Fedorenko

Myroslava Kulesha-Liubinets

Elena Ruban

Yuliia Hundertailo
DIR $®$-informed approach to anxiety and trauma in school age 6 children

Anxiety and informal education (cross-cultural aspect)

Physical development as a chance for autism

Characterological and Psychological Peculiarities of women with eating behavior disorders

Main tendencies in modern psychology

Features of the emotional-volitional sphere of persons with vascular diseases of the brain

Conscious Choice of a Healthy Lifestyle as a Manifestation of Safe Personal Behavior in Adulthood

Psychological condition and resocialization of widows and grieving mothers in conditions of modern Ukraine

Art and psychosis: Elements of psychopathology in the work of Edgar Allan Poe. The case of tale tell heart

Training in the restoration of communication skills of the individual "Way Home"

Aspects of mental health protection in military service in the conditions of military action and in the adaptive period

Mental health and communication risks: socio-psychological support of the individual in the process of adaptation to peaceful life

Mental Health Levels among University Students - Bordj Bou 50 Arreridj University as a Model

What is "good", what is "bad"? Experience of Institutional 51 (medical) system of MHC

The staff and patients of MHC medical Institutions as a small social groups. Interpersonal and intergroup relations

Development of confidence of musicians-beginners in 55 preparation for performance activities

Features of the Idea of University Students About Mental Health

Mental health and art therapy: socio-psychological support of IDPs in the process of adaptation to peaceful life

Iryna Gayova, Iryna Romash, Ivan The Clinical Practice's Case. Syndrome of Megacytolysis at the 
Romash, Neogi Reevu

Natalya Guba, Natalya Mosol

Elena Kazannikova

Mykola Kostenko

Olena Malyna

Iryna Romash

Ivan Romash, Mukhailo Vynnyk, Iryna Romash, Anna Polinyk, Olena Yevchyk

Alina Maria Breaz

Oksana Los

Olga Korobanova

Yulia Paskevska

Larysa Spitsyna

Olena Kosyhina

Evheniia Geyko

Iryna Kryvenko
Patient with the Ischemic Stroke

Perinatal psychological support, counseling and education 68

$\begin{array}{ll}\text { Parameteres of mental health in childhood } & 71\end{array}$

Psychological bases of human health

Destigmatizing direction of psychologist's work in the field of 77 mental health care

Peculiarities of individual indicators of collagen metabolism 80 and level of matrix metalloproteinase-9 in case of gastroesophageal reflux disease in patients with syndrom of undifferentiated connective tissue dysplasia

symptoms in students from medical university in the period of altered psychoemotional status

New methods for insuring psychic health in adolescents in the residential environment

The role of sexual education in preschool mental health care

Group psychological phenomena and mental health preservation 90 in complex social situations

Monitoring of human rights in the area of mental health: European and national dimensions

System supervision tasks for practicing psychologists at the initial stage of professional activity

Professional health care program as a basic personal 103 development resource

Poly-systemic integrity of the personality

Subjective well-being in late adulthood: the views of elderly 


\title{
"DIR®-informed approach to anxiety and trauma in school age children"
}

\author{
Galina Itskovich \\ Interdisciplinary Council on Development and Learning, New York, USA
}

\begin{abstract}
.
This paper examines presenting problems of latency age children, stemming from anxiety and/or psychological trauma of various kinds. An author shares experience in addressing symptomatology from the cluster of anxiety disorders in therapeutic work, using Developmental, Individual differences and Relationship based approach (DIR $\left.{ }^{\circledR}\right)$ originated by Stanley Greenspan and Serena Wieder. Developmental, Individual differences and Relationship model describes the developmental capacities to achieve throughout the formative years of human life, unique ways of information processing (this includes motor control, praxis, visual spatial capacities and integration of sensory information supplied by five organs of sense and vestibular, visceral and proprioceptive systems) and language capacities, and affective relationships promoting all the above.

DIR ${ }^{\circledR}$ model can be utilized for the purpose of differential diagnosis; it also provides an invaluable philosophical base. This diagnostic and treatment paradigm allows scrutiny of co-occurring problems, developmental capacities and multitude of variations in sensory, medical, familial and environmental characteristics that serve as prequel to symptoms. Additionally, DIR ${ }^{\circledR}$ approach lends us not only understanding of the impact of individual differences on anxiety manifestations, but also treatment philosophy that leaves room for the individuality of the child. In Erik Erikson's terms, school age children resolve issues of inferiority versus industry; they can greatly benefit from therapeutic relationship that promotes a sense of competency.

As dwellers of our planet get overwhelming amount of information and live coverages of scary, traumatizing and horrifying events around the globe, anxiety takes the front seat in the clinical landscape. Children are more susceptible to anxiety mainly because of lack of control over their lives, actual helplessness, operating largely on clues and adult whisper rather than on confirmed (and comprehended by them) facts and, frequently, having no impact on own future. Because of linguistic limitations of different nature (age-appropriate limited vocabulary or delayed speech development), children are shortchanged in their choice of neuro-integration via verbalization of experiences, worries or fears. As a result, instead of labelling their prevailing emotion of the hour as anxiety, they present many changes in behavior, from school refusal to psychosomatic problems to behavioral storms. Naturally, all the above greatly depends on individual patterns of resilience. Prior history of trauma is the most important marker of emerging symptoms of anxiety and anticipatory anxiety. Mechanisms of processing, as well as history of trauma and vicarious trauma should be closely examined in the process of assessment and addressed in treatment regardless of the scope of presenting problem.

Another, not less important, predictor of anxiety is ability to self-regulate and the speed with which the child can recover from stress or perceived danger and, shutting down the initial response of hypervigilance, go back to the state of
\end{abstract}


homeostasis. Excessive anxiety can manifest itself as aggression, "striking out", low frustration tolerance and impulsivity. Additionally, many highly anxious children may struggle with issues around sensory reactivity that usually go unnoticed and unaddressed. Sensory reactivity can put such children in the perpetual (or frequent) state of sensory overload, when anxious mood is exacerbated by the malfunctioning ability to process sensory information. Helping children to recover from the emotional and sensory overload means decrease in self-blame, in polarized and inflexible thinking, anticipatory anxiety, and senses of helplessness and inadequacy.

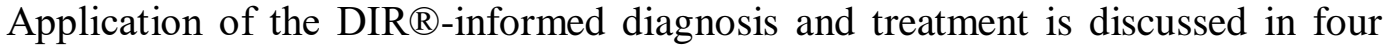
case examples: dealing with the hostile environment; sense of impending doom based on prior experience; living in the uncertain future; and being "an unwanted child" and dealing with anxious attachment. DIR ${ }^{\circ}$-informed treatment calls for respect. Its unique premise is following the child, thus returning them a "missing link" - a sense of competence and control instrumental to alleviation of symptoms.

Keywords: DIR ${ }^{\circledR}$, anxiety, psychological trauma, school aged children, differential diagnosis, therapeutic use of self 
ANXIETY AND INFORMAL EDUCATION (CROSS-CULTURAL ASPECT)

\author{
D. Kolodych ${ }^{1}$, Kateryna Milutina ${ }^{2}$, Vsevolod Zelenin ${ }^{3}$, Tetiana Andrushchenko $^{4}$ \\ ${ }^{1,2}$ Kyiv National Taras Shevchenko University, Kiev, Ukraine \\ ${ }^{3}$ National Pedagogical Dragomanov University, Kyiv, Ukraine \\ ${ }^{4}$ National Pedagogical Dragomanov University, Kyiv, Ukraine
}

\begin{abstract}
.
Introduction. Secondary education system in the post-soviet countries experience a significant crisis - traditional methods of education lose their significance under the influence of information society development and globalization. The courses, trainings, distance learning and other forms of informal education is starting to spread instead. Therefore, research of the informal education influence on its participants` mental health is particularly relevant.
\end{abstract}

Purpose. The purpose of the study was to identify the mutual anxiety of parents and students from staying in the informal education system in two countries with different mentality - Ukraine and Vietnam.

\title{
Design/Methodology/Approach
}

The study had two stages: a survey of parents whose children are involved or not involved in informal education and a survey of teen students involved in traditional and informal education systems. The participants of a survey were 215 parents having school age children (143 Ukrainian and 72 Vietnamese). All of the Ukrainian surveyed parents were residents of large cities of Ukraine: Kyiv, Kharkiv, Lviv and Dnipro, where exists the wide range of non-formal education options; Vietnamese participants are residents of Biên Hòa city, Dong Nai province. In total, these parents have 346 children who are involved in different educational options. For this research we used E.S. Schaefer`s and R.Q. Bell's Parent Attitude Research Instrument (PARI) in adaptation of T. V. Nescheret, Spielberg-Hanin test of state anxiety level and author's questionnaire. In addition, we examined Ukrainian and Vietnamese children enrolled in general education schools, in distant learning and in combined general-informal education with English courses. In total 208 children were studied, 140 of them are Ukrainian and 68 are Vietnamese. For children` survey we used Phillips`School Stress and Anxiety level test and Pip Wilson`s Blob Tree test.

The study found that the parents` choice of the educational form for their children depends on such peculiarities of parental attitudes as anxiety, overprotection desire, excessive control and their own schooling and informal education experience. Due to obvious "polarization" of indicators in two groups of Ukrainian parents with informal education, they were divided into two different 
subgroups depending on the level of anxiety. We've done an analysis of the differences between the medians in the different groups according to the KruskallWallis criterion and an analysis of the differences between the two groups according to the Mana - Whitney criterion, which shows us significant differences by this parameter. According to cluster analysis participants divided into five groups. The first cluster includes parents whose children are not involved in the informal education system. They show a low level of anxiety, do not tend to excessive care and overprotection, 22\% of Ukrainian parents and 64\% of Vietnamese parents belong to this cluster. Parents of children who attend one or two clubs or sections have an average level of personal anxiety, a low level of situational anxiety. These are $28 \%$ of Ukrainian parents, $36 \%$ of Vietnamese. Another cluster includes parents whose children attend three or more clubs and sections, they are anxious, often interfere the child's inner world, seek early development, and find it necessary to overcome the child's resistance. This group is large in Ukraine - $41 \%$ and is absent in Vietnam. Parents of children who involved only in the informal education system divided into two quite different groups. One mainly consists of the parents of healthy children who have deliberately chosen homeschooling. They are anxious, focused on overprotection and isolation of children. There is also a focus on excessive interference to the child`s world and the desire for its accelerated development (6\%). Another group are parents of children with special needs who forced to resort to informal education due to the disadvantages of inclusive education. They are less anxious; do not tend to overprotection, but want to accelerate the development of their child and control it enough (3\%). The last two clusters investigated only in Ukraine.

By the way, we noted that traditional education caused a feeling of fatigue, avoidance of educational activity in the Ukrainian students, whereas informal learning was associated with difficulties overcoming, success, and friendly support.. Maximum faced anxiety in students who only attended school in Ukraine. Vietnamese students showed significantly lower levels of anxiety instead. In contrast to the Ukrainian, Vietnamese students had no experience of distant learning; they visited general schools and foreign language courses. The children were well adapted to traditional education, focused mainly on leadership, achievements and friendship with peers. We could explain this by the fact that Asian culture is more collectivist and by the fact that successful study is a step towards career growth and improvement of social status in Vietnam. Informal education is perceived more as a place for entertainment, friendly communication with mentors and peers, and has not led to increased anxiety in either Ukrainian or Vietnamese students.

\section{Practical/Social value}

- The data obtained became the basis for building a system of socializing influence for informal education in English language courses for both countries,

- Revealed category of over anxious parents in need of psychological support, 
- Regular informal education involvement (1-2 sections) can be considered as a prevention of excessive anxiety and apathy in schoolchildren.

Conclusions. The conditions of educational socialization (formally, distant and informal education) significantly influence the development of teenage personality and their self-attitude. Informal education was the most prosperous environment for the Ukrainian teenagers studied. The level of parental anxiety contributes to inadequate choice of education and leads to negative family education styles. Prospects for further research - development of an optimal strategy of psychological support for children and teenagers of different cultures in the context of informal education.

Keywords. Informal education, anxiety, parental attitude, school, self-esteem

(C) NDSAN (MFC - coordinator of the NDSAN), Italy, 2019 


\title{
Physical development as a chance for autism
}

\author{
Olena Koshelieva \\ Kyiv, Ukraine
}

\section{Introduction}

The topic of Autism is relevant today in Ukraine as well as through out the world. Meanwhile, the number of people with autism in Ukraine today remains unknown because of the lack of statistics, difficulty in diagnosing and other problems in herent to the country, which only recently began to recognize the existence of this problem.

In the Soviet Union, as we know, autism "didn't exist": children with autism who had reached the adult age were just receiving a diagnosis of "Schizophrenia."

Nowadays in our country it is still hard for the parents to get autism diagnosed due to insufficient finances and the lack of specialists in this field. With an early childhood autism diagnosis, an adult diagnosis can still be turned into schizophrenia.

5 actual problems for people with autism in Ukraine - 2019

1. Lack of specialized experts.

2.The difficulty of obtaining the diagnosis.

3.Complications with getting accepted into schools.

4. Impossibility to start the correction therapies in time.

5. The inability to get a pre-school education.

The system of inclusive education remains an urgent problem. Students are only superficially untroduces to this activity, but they are not taught how to professionally do correction therapy work with such children in Ukrainian universities. Many children stay at home or in specialized day care centres. Their future remains a question and anxiety for parents.

Most of all, Ukraine lacks speech therapists, defectologists, physiotherapists, massage therapists, and trainers.

Some parents acquire a second profession and retrain for psychologists, doctors, pathologists, psychologists, open rehabilitation centres, work in organizations for early intervention, supervise associations for autism, create teaching materials, educational videos, visual communication folders (Pecs cards), become ABA therapists, Flortime therapy specialists, create charity foundations and active civil organizations, organize conferences, entertainment festivals, summer camps to improve the development of their children.

As a result, having pedagogical, creative, coaching experience and noticing the problem of Autism, I could not stand aside and began to study this problem.

I gathered a group of children and parents and started training with them in the Central Sports Club of the Armed Forces of Ukrainein Kiev on the first of September 2018.

\section{Purpose}

Thus, the aim of the study is to describe an effective tool - playing sports, a healthy position towards the perception of the physical development of the parent and child as prerequisite for mental well-being ( as a chance for autism)

To show and prove that physical development not only reduces and reduces the risk of heart disease, diabetes and obesity, but it is especially important that it gives many benefits to people with autism. This leads to improved communication and socialization, cognitive abilities, sensory and behavioral changes. 


\section{Methods}

The methods which I use are all about combination of physical trainings and creation of special atmosphere. This is the Adaptive fitness method.

Our «Adaptive Fitness» today - programme is different types of game activity in the group: Group game training, Elements of boxing, Elements of crossfit, exercises in the gym, Tennis, Stretching, Yoga.

Training is aimed at coordinating, forming good posture, forming the musculoskeletal system, improving the visual analyzer, improving visualization, proprioception, feeling the body in space, feeling and understanding parts of the body, adapting the whole organism to fitness. This is the joint work of children and parents on unification, endurance, strength, positive.

The first part of the session is held in the boxing hall, the second part is in the gym. We finish the training with Yoga + Encouragement. In training, I use a stopwatch, whistle, hourglass, adjustable backlit music, different melodies in the process of active training and quiet tasks.

We have our own rituals - at the beginning and at the end of the workout, the children sit in a circle. For such children, this brings an important understanding of the beginning and end of training, this is a moment of calmness and safety. This is a special magic of unification and joint power.

Sometimes my external image is different - I am the hero of a cartoon, or I have a face painting, or bright sneakers and a T-shirt. Children also sometimes draw and try something on themselves: they draw a face painting, wear attributes — a bright captain's cap or a bright Tshirt.

We also make massage with fitballs, such as rest, relaxation, calmness, adaptation between transitions from one room to another. The massage is also accompanied by light music.

So, I select the exercises for such children and direct them to activate the work of the two hemispheres, where there are also cross-movements of the arms and legs, exercises for balance, coordination, the use of boxing elements, bilateral body work.

Also, there are relays, team games, tug-of-wars, jumping rope, crawling, running, criss-cross, dance moves. For example, you are with us in the boxing hall and can step into the ring and wear real boxing gloves - for some children this is a dream!

As you know, it's better to see once than to hear a hundred times. Same for these people, especially initially, visualization is needed for support, calmness, understanding.

I developed my cards with the names for each fitness attribute and exercise machine in the gym. For the younger group there are their own tasks on the tablet-roulette, and for the older group there are separate independent tasks on the cards (4-5 cards each, which can be advanced by repeats / sets).

I recommend additional exercise videos to parents in our group on Facebook (https://www.facebook.com/helena.koshelewa

(https://www.facebook.com/groups/446610632493929/permalink/656056634882660/),

On youtube xsport 1

Https://www.youtube.com/channel/UCR_5Oj-atqmvc8mjas3sszq )

(http://trenirovka.in.ua).

At the end of the training, each participant receives a treat (fruit, sweetness), passing the sensory ball in a circle, saying "I am amazing. I did great!".

The great part of work I do with mothers: it's very good for them to meet each other, to consult with me about healthy food and the food for their special children. It is also very important to do physical trainings with mothers for their beauty, health, weight loss, healthy muscle tone, joy and the sense of life and wish to create something better. I think that happy mother is a way to health and strong child.

\section{Results}


Now I already have regular classes with autistic children, children with Asperger syndrome and others.

We have two groups: the youngest (5-10 years) and the older group (11-20 years). And the number of children grows constantly. Training takes place every Saturday at a fixed time in the rented rooms of the Central Sports Club of the Armed Forces of Ukraine. The duration of the training session is 60 minutes.

Due to my project I see the results now: children adapt well in groups, their socialization is much better, behavior and discipline becomes much better in competitive relays. The proprioception, visualization and coordination works on trainings.

We have a group on Facebook, where we share with our parents the results and impressions, we invite mothers to individual trainings, to joint family trainings, and to field trips and photo shoots.

\section{Limitations and strengths of the study}

Many understand that physical activity is vital for a healthy lifestyle for all people, it reduces the risk of heart diseases, diabetes and obesity, and what is especially important - physical development provides many benefits for people with autism. This leads to improved communication and socialization, cognitive abilities, sensory and behavioral changes.

Exercises, sports, Adaptive fitness - help to be more:

- independent (in group training, in a team, in the locker room, in communication),

- disciplined (when performing independent tasks, listen to the coach, communicate with peers, prepare a sports bag for training),

- confident (doing all the tasks assigned + encouragement, winning the relay race)

- conscious in his body (feeling the body when performing tasks).

12 Advantages of Adaptive Fitness:

1. Reducing maladaptive behavior

2. The increase in long-term concentration of attention to the tasks implementation.

3. Gaining confidence, independence

4. Getting rid of toxins from the body, improving health

5. Improving mood from depression, anxiety

6. Improving discipline

7. Improving the development of speech and academic skills

8. Reduction of echolalia (verbal repetition of phrases or words)

9. Reduction of stimming (waving hands, jumping in one place, self-torture, which are the usual behavior in autism).

10. Awareness of your body in space,

11. Meaning of body parts

12. Adaptation and socialization

As I see now, classes on my system Adaptive Fitness are very effective for developing strength, attention, coordination, socialization, physical and psychological health. The combination of physical exercises, loads, training in a group for children and mothers and creating a special atmosphere - give positive results.

\section{PracticallSocial value}

When you work with people with autism, they learn - by observing the onesbe side them, repeating after you - you need to be an active model, teacher, inventor of interesting and relevant sports tasks.

I recommend:

1 Daily physical activities

2 Healthy food

3 Being an active example to your child. 
Take a closer look at the needs and abilities of the child, enter physical activities into child's and your schedule.

Never give up and believe in what your child can do and you can be its leader!! Autism affects each child differently. Find the kind of activity that your child likes and needs for his health.

The motivation of parents to attract a child to such activity is the active actions of the parents themselves! Instead, you get a socialized, adapted to the life child with improved processes in development. Implementing these powerful concepts can create healthy minds and bodies that are vital for the growth and development of our children.

Motivation of children - group workouts with peers - socialization, games with other children, positive, encouragement (emoticons, fruits, treadmill, favourite game), positivity from the process of training.

It works! (And it clicked!)

\section{Originality $\backslash$ Conclusions}

Future and prospects - there is! Physical development is a chance for autism!

Parents that are interested can direct themselves and their child to learn the specifics of cooking, medical ("Good Doctor" series), coaching activities, and be a sports blogger promoting healthy lifestyles.

1. Create inclusive sports centres - it will gain a healthier society, friends, active participants adapted to life. This could be a boxing gym, a gym, a hall for choreography, rock climbing, roller tracks, tennis courts, hippotherapy, a swimming pool, a healthy food, restaurants, and spa services.

2. Promote a healthy lifestyle - it will attract more friends and improve the quality of life for others.

The world of activities and sports fantasies is diverse! Teach yourself and your child to move! With any schedule, you must engage in physical activity and make it a daily goal. For most people, exercise is just talking. Healthy active parents - healthy children!

Physical development and training should be part of your life! Raise the skills of a healthy lifestyle for a healthy society and the future!

Keywords. Autism in Ukraine, Fitness for people with disabilities, fitness for Aspergers, Fitness for people with autism, Adaptive fitness, Adaptive fitness in Kiev, Exercises for autism, Exercises for activating the brain, Neuro correction, Top 12 Benefits of adaptive fitness, training for special mothers, Recommendations for a fitness trainer, The future of people with autism, fitness trainer Helena Koshelewa, coach Olena Koshelieva 


\title{
Characterological and Psychological Peculiarities of women with eating behavior disorders
}

\author{
Nataliya Lisova \\ IAPM, Kiev, Ukraine
}

Introduction. Concerns about overweight are especially prevalent among women, which is largely aided by media that promote certain standards of feminine beauty and promote various ways to lose weight. Public stereotypes consider the perfect slim woman with a figure inaccessible to the vast majority, causes a sense of inadequacy in women, more or less inclined to fullness.

Purpose of the paper is to highlight current researches on eating behavior disorders among women, and to define characterological peculiarities related to the disorders of eating behavior of women.

Results. The characteristic features of overweight women are frequent depression; addictive behavior, general impulsivity and destructive-compulsive behavior; verbal aggression, violent outbursts; tendency to use the symptoms of their somatic diseases as a means of avoiding responsibility; the desire to attract attention, demonstrative, superficial feelings and interests

Conclusions. Early signs of impaired eating behavior are changes in psychological status, characterized by the appearance of adverse mental reactions: anxiety, frustration, rigidity, irritability and aggressiveness

Keywords: women, eating behavior, psychological qualities 


\section{Характерологічні та психологічні особливості жінок з надмірною}

\section{масою тіла}

Наталія Лісова,

МАУП, Київ, Україна

Актуальність. Стурбованість 3 приводу надмірної маси особливо поширена серед жінок, чому в великій мірі сприяють засоби масової інформації, що пропагують певні стандарти жіночої краси і рекламують різні способи схуднення. Суспільні стереотипи вважають ідеальною струнку жінку з фігурою, недосяжною для переважної більшості, викликає відчуття неадекватності у жінок, більш-менш схильних до повноти.

Мета статті полягає у огляді сучасних досліджень з проблеми розладів харчової поведінки у жінок та визначенні характерологічних особливостей, взаємопов'язаних 3 порушеннями харчової поведінки у жінок

Результати. Характерологічними особливостями жінок з надмірною вагою вважаються часта депресія; залежність, загальна імпульсивність і деструктивнокомпульсивна поведінка; словесна агресія, вибухи люті; схильність використовувати симптоми своїх соматичних захворювань, як засіб уникнення відповідальності; прагнення звернути на себе увагу, демонстративність, поверховість почуттів $\mathrm{i}$ інтересів

Висновки. Ранніми ознаками порушеної харчової поведінки $є$ зміни у психологічному статусі, які характеризуються появою несприятливих психічних реакцій: тривожності, фрустрації, ригідності, дратівливості та агресивності

Ключові слова: жінки, харчова поведінка, психологічні якості

Актуальність. Останнім часом зростає інтерес дослідників до психологічних аспектів ожиріння, поширеність якого в економічно розвинених країнах, за статистикою ВООЗ, досягає $30 \%$, та $є$ фактором ризику не тільки для виникнення проблем зі здоров'ям, але i, порушує соціальну адаптацію та сприяє розвитку дисфункції психіки.

Будучи проблемою, яку важко приховати від оточуючих, надлишкова маса призводить до значного психологічного ризику, зумовленого існуючими в суспільстві негативними установками по відношенню до повних людей. Стурбованість 3 приводу 
надмірної маси особливо поширена серед жінок, чому в великій мірі сприяють засоби масової інформації, що пропагують певні стандарти жіночої краси і рекламують різні способи схуднення. Сучасне суспільство, вважаючи ідеальною струнку жінку 3 фігурою, недосяжною для переважної більшості, викликає відчуття неадекватності у жінок, більш-менш схильних до повноти. Тому вивчення психологічних особливостей таких жінок є досить актуальним.

Мета статті полягає у огляді сучасних досліджень 3 проблеми розладів харчової поведінки у жінок та визначенні характерологічних особливостей, взаємопов'язаних 3 порушеннями харчової поведінки у жінок.

Результати. Ожиріння лише в 5\% випадків є симптом якогось органічного захворювання. $\mathrm{y} 95 \%$ випадків в його основі лежить нейрохімічний дефект церебральних систем, які регулюють харчову поведінку і гормональний статус (Greeno, Wing, 1994). При цьому у 60\% хворих на ожиріння має місце патологія харчової поведінки, і їм досить власної сили волі і самоконтролю для успішної боротьби із зайвою масою.

Харчова поведінка - сукупність звичок, пов’язаних з прийомом їжі - наші смакові переваги, режим прийому їжі, дієта. Харчова поведінка залежить від багатьох факторів - особливостей культури, виховання, матеріальних можливостей, біологічних особливостей.

Ожиріння - хронічне мультифакторне гетерогенне захворювання, що виявляється надлишковим утворенням жирової тканини, прогресуюче при природному протіканні. Як правило, його супроводжують високий кардіометаболічний ризик, специфічні ускладнення, з ним асоціюються різні захворювання.

Традиційно дослідження ожиріння і харчової поведінки не були зв'язані один 3 одним і проводилися в рамках різних підходів. Ожиріння розглядалося як медичне захворювання, що має генетичну і метаболічну природу, найбільш ефективними способами лікування якого вважалися дієта, лікарські засоби або хірургічне втручання (Бессесен, Кушнер, 2006). На противагу цьому в психіатрії та психотерапії порушення харчової поведінки (нервова анорексія і булімія) розглядалися як синдроми, існуючі переважно в західній культурі, що виникають в суспільствах з надмірним акцентом на проблемах ваги, форми і зовнішнього вигляду, ефективно виліковувати за допомогою когнітивно-поведінкової та сімейної психотерапії (Малкіна-Пих, 2005). 
В даний час в медичній психології існує явний дефіцит досліджень ролі особистості в формуванні харчової поведінки клієнтів з ожирінням, у яких немає вираженої психопатології і які становлять більшість популяції людей з ожирінням. Звідси випливає, що в більшості випадків психотерапія може бути єдиним або основним методом в програмі схуднення.

Харчова поведінка людини оцінюється як гармонійна (адекватна) або девіантна залежно від багатьох параметрів, зокрема, від місця, яке займає прийом їжі в ієрархії цінностей індивіда, від якісних і кількісних показників харчування, від естетики. Важливими є фактори вироблення стереотипів харчової поведінки, особливо в період стресу. Одвічним питанням щодо цінності харчування є його зв'язок 3 життєвими цілями («їсти, щоб жити чи жити, щоб їсти»), врахування ролі харчової поведінки для становлення деяких особистісних характеристик (наприклад, гостинність) (Данильченко, 2004).

Серед порушень харчової поведінки виділяють обмежувальну, екстернальну і емоціогенну харчову поведінку. Обмежувальна харчова поведінка характеризується навмисними зусиллями, спрямованими на досягнення або підтримання бажаної маси за допомогою скорочення споживання калорій. Результати багатьох досліджень показали, що при дистрессі кількість їжі, що з'їдається збільшується у тих, хто дотримується дієти, і зменшується у тих, хто дієту не дотримується (Малкіна-Пих, 2005). Екстернальна харчова поведінка пов'язана 3 підвищеною чутливістю до зовнішніх стимулів до прийому їжі: запаху їжі, ії зовнішньої привабливості, доступності харчових продуктів. При цьому люди їдять незалежно від того, голодні вони чи ні. При емоціогенній харчовій поведінці бажання поїсти виникає у відповідь на негативні емоційні стани, такі як тривога, страх, гнів, розчарування, пригніченість, нудьга і ін. Відповідно до психосоматичної гіпотези (Kaplan, Kaplan, 1957) ожиріння є наслідком нездатності до розрізнення почуття голоду і стану тривоги, в результаті чого індивід реагує на стрес, як на голод, збільшуючи споживання їжі.

Ранніми ознаками порушеної харчової поведінки $є$ зміни у психологічному статусі, які характеризуються появою несприятливих психічних реакцій: тривожності, фрустрації, ригідності, дратівливості та агресивності. Такі реакції виступають в якості ранніх психологічних критеріїв неврогенних розладів харчування (Менделевич, 2005).

Останнім часом фокус досліджень перемістився з питання про те, чи пов'язано ожиріння 3 психологічним дистрессом, на питання, які люди 3 ожирінням мають 
підвищений ризик психопатології. В рамках цього підходу J.Istvan $з$ співробітниками (Istvan, Zavel, Weidner, 1992) розглянули взаємозв'язок між індексом маси тіла і депресією на репрезентативній сукупності у дорослих 25-74 років. Вони не виявили взаємозв'язку між індексом маси тіла і депресією серед чоловіків, але виявили, що жінки з індексом маси тіла більше 28,96 кг / м² в 38\% випадків мали клінічно значущі депресивні симптоми в порівнянні з жінками з меншим індексом маси тіла. Результати лонгитюдних досліджень показали, що депресія передує ожирінню у дівчаток-підлітків, але не у хлопчиків, і що ожиріння передує депресії у дорослих (Istvan, Zavel, Weidner, 1992). У свою чергу, такі фізіологічні прояви, як розлади апетиту, значні зміни маси тіла, а також такі поведінкові прояви, як залежність, загальна імпульсивність і деструктивно-компульсивна поведінка, є симптомами депресії (Пезешкіан, 1996).

При порушеннях харчової поведінки досить часто спостерігається депресія. Проте поки не існує наукових даних, що дозволяють 3 усією визначеністю стверджувати, яке з цих порушень виникає першим і чи існує між ними причиннонаслідковий зв'язок.

Питання про взаємовідносини надлишкової маси, переїдання i агресії представляє особливий інтерес. Доведено, що емоціями, з якими найбільш пов'язано булімічну поведінку, є тривога, депресія і гнів (Kaplan, Kaplan, 1957). К. Ізард (Musante, Costanzo, Friedman, 1998) зазначав, що, коли людина засмучується з приводу своєї надлишкової маси або боїться набрати зайву вагу, має місце взаємодія харчового драйву з емоційним патерном «печаль- гнів»: людина їсть, щоб звільнитися від печалі, і при цьому картає себе за нестриманість.

К. Хорні (Хорні, 2000) вважає, що ненаситність, що виявляється в жадібності як спільній рисі характеру і виявляється в їжі, є однією з характерних особливостей невротичної потреби в любові, причому жадібність може виникати або посилюватися, коли зростає ворожість або тривожність. Результати дослідження R.-J. Milligan, G.Waller (Milligan, Waller, 2000) в дослідженнях за допомогою методики Спілбергера показали, що переїдання пов'язано з високим рівнем прихованого гніву і виконує функцію уникнення його переживання, а блювота - 3 високим рівнем стану гніву i полегшує, таким чином, цей стан.

Порівняльне дослідження рівня агресії, проведене за допомогою опитувальника Басса - Дарки у людей з надмірною і нормальною масою, дозволило встановити, що у випробовуваних 3 надмірною масою і їі коливаннями рівень ворожості значно вище, 
ніж у випробовуваних з нормальною і стабільною масою (Ізард, 2000). Це пояснюють фрустрацією і незадоволеністю, які пов'язані з неможливістю підтримувати досягнуту після чергової дієти масу тіла. У всіх повних жінок виявилися вищими індекси агресивності і ворожості, показники вербальної, фізичної і непрямої агресії, образи і підозрілості. Згідно з цими результатами повні жінки більш схильні до вираження своїх негативних почуттів через форму і зміст словесних звернень - криками, лайкою, погрозами, а також до прояву ненапрямлених вибухів люті, що виражаються, наприклад, в шпурлянні речей, грюкання дверима при догляді, стукання по столу і т.п., тобто в непрямій агресії. У повних жінок більш виражена схильність до недовіри і обережного відношенню до людей, що виникає 3 переконання, що оточуючі мають намір заподіяти їм шкоду, - наслідок проекції власної ворожості на оточуючих. Виражене у повних жінок відчуття несправедливості по відношенню до них долі або інших людей часом проявляється у вигляді заздрості і ненависті до людей.

Досліджуючи вплив ідеалу жіночої краси на настрій і задоволеність тілом у жінок, L. Pinhas et al. (Pinhas, Toner, Ali et al, 2000) відзначили підвищення рівня депресії і гніву у жінок після перегляду моделей, які рекламують жіночий одяг, причому жінки, особливо не задоволені своїм тілом або мають такі психологічні особливості, пов'язані з порушенням хачової поведіки, як міжособистісну недовіру і почуття неефективності, виявилися більш схильними до впливу цих образів , ніж інші випробовувані.

Люди сприймають себе такими, що володіють небажанною ідентичністю, яку вони самі собі або інші їм приписують характеристики, що підривають їх ідеальний образ «Я». Переживання 3 приводу володіння небажанною ідентичністю викликає почуття сорому, яке обертається переживанням гніву.

В результаті дослідження образу тіла з'ясувалося, що жінки 3 надлишковою масою набагато частіше відчувають дискомфорт з приводу своєї зовнішності. Однак жінки, які повні з дитинства, на відміну від розповнівших жінок не засмучувались, порівнюючи свій актуальний зовнішній вигляд 3 тим, який був у них в більш ранньому віці. У жінок, повних з дитинства, надлишкова маса не впливає на потребу в спілкуванні.

За даними Ю.Л. Савчикової (Савчікова, 2005), результати опитувальника Міні-мульт свідчать про недостатню гнучкість, злопам'ятність повних жінок, їх схильність до формування надцінних ідей, наприклад ідеї про несхвальне ставлення до них 
оточуючих або ідеї схуднення. Дані опитування жінок, що страждають на ожиріння, в порівнянні з контрольною групою говорять про їх тенденції використовувати симптоми своїх соматичних захворювань, як засіб уникнення відповідальності, в тому числі за надмірну масу, а також про прагнення звернути на себе увагу, демонстративності, поверховості почуттів і інтересів. У жінок, розповнілих в дорослому віці, також було виявлено найвищі показники депресії і психастенії.

У всіх повних жінок часте відчуття дискомфорту з приводу свого тіла було пов'язане з депресією. Однак тільки у жінок, які розповніли в дорослому віці, невдоволення своїм тілом корелювало з реальним збільшенням індексу маси тіла. У цих жінок і в контрольній групі був виявлений взаємозв'язок невдоволення власним тілом з переїданням (показниками екстернальної і емоціогенної харчової поведінки), в той час як у жінок, повних $з$ дитинства, невдоволення власним тілом було пов'язано 3 нездатністю або небажанням обмежувати себе в їжі. Показники опитувальника Мінімульт за шкалами психопатії, паранойяльності i шизоидности корелювали 3 показниками екстернальної хачової поведінки у жінок, повних 3 дитинства, i обмежувальної - у розповнілих.

\section{Висновки.}

- У 95\% випадків в основі ожиріння лежить нейрохімічний дефект церебральних систем, які регулюють харчову поведінку і гормональний статус

- Ранніми ознаками порушеної харчової поведінки $є$ зміни у психологічному статусі, які характеризуються появою несприятливих психічних реакцій: тривожності, фрустрації, ригідності, дратівливості та агресивності

- Характерологічними особливостями, взаємопов'язаними 3 порушеннями харчової поведінки у повних жінок, є поєднання підвищеної чутливості 3 емоційною холодністю i відчуженістю в міжособистісних відносинах, конфліктність, агресивність, нестійкість настрою, образливість, невпевненість в собі, схильність до тривоги.

\section{Література:}

1. Бессесен Д.Г., Кушнер Р. Избыточный вес и ожирение. М.: БИНОМ, 2006.

2. Вознесенская Т. Г., Сафонова В. А., Платонова Н. М. Нарушение пищевого поведения и коморбидные синдромы при ожирении и методы их коррекции // Журн. неврол. и психиатр.— 2000.— № 12.— С. 49-52. 
3. Крылов В. И. Пограничные психические заболевания с нарушениями пищевого поведения.- С.Пб.: Изд. дом «Шанс», 1995.- 112 с.

4. Креславский Е. С. Избыточная масса тела и образ физического Я // Вопр. психол.1987.— № 2.— C. 113-117.

5. Малкина-Пых И.Г. Психосоматика. Справочник практического психолога. М.: ЭКСМО, 2005.

6. Менделевич В.Д. Клиническая и медицинская психология: учебное пособие для вузов. 5-е изд. М.: МЕДпресс-информ, 2005.

7. Пезешкиан Н. Психосоматика и позитивная психотерапия.- М.: Медицина, 1996.

8. Greeno C.G., Wing R.R. Stress-induced eating // Psychol. Bull.— 1994.— Vol. 115, № 3.- P. 444-464.

9. Kaplan H.I., Kaplan H.S. The psychosomatic concept of obesity// J. of Nerv. and Ment. Dis.— 1957.— Vol. 125.— P. 181-201.

10. Musante G. J., Costanzo P. R., Friedman K. E. The comorbidity of depression and eating dysregulation processes in a diet-seeking obese population: A matter of gender specificity // Int. J. Eat. Dis.— 1998.— Vol. 23, № 1.— P. 65-75.

11. Савчикова Ю.Л. Психологические особенности женщин с проблемой веса: дисс. канд. психол. наук. СПб., 2005.

12. Arnow B., Kenardy J., Agras W.S. The emotional eating scale: the development of a measure to assess coping with negative affect by eaters // Ibid. - 1995. - Vol. 18. - P. 7990.

13. Изард К. Э. Психология эмоций: Пер. с англ.- С.Пб.: Питер, 2000.-264 с.

14. Хорни К. Невротическая личность нашего времени: самоанализ.- М.: Прогресс; Ювента, 2000.- 480 с.

15. Milligan R.-J., Waller G. Anger and bulimic psychopathology among nonclinical women // Int. J. Eat. Dis.— 2000.— Vol. 28, № 4.— P. 446-450.

16. Carmody T. P., Brunner R. L., Jeor S. T. St. Hostility, dieting, and nutrition attitudes in overweight and weight-cycling men and women // Ibid.— 1999.— Vol. 26, № 1.- P. 37-42. 17. The effects of the ideal of female beauty on mood and body satisfaction / L. Pinhas, B.B. Toner, A. Ali et al. // Ibid. - Vol. 25, № 2.— P. 223-226.

18. Вознесенская Т. Г., Дорожевец А. Н. Роль особенностей личности в патогенезе церебрального ожирения // Сов. мед.-1987.— № 3.— С. 28-32. 
19. Ferguson T. J. Unwanted Identities: A Key Variable in Shame-Anger Links and Gender Differences in Shame // Sex Roles: A J. of Research. Feb, 2000.— P. 83-92.

20. The Dutch Eating Behavior Questionnaire (DEBQ) for Assessment of Restrained, Emotional, and External Eating Behavior / T. van Strien, J.E.R. Frijters, G.P.A. Bergers, P.B. Defares // Int. J. Eat. Dis.— 1986. - Vol. 5, № 2.— P. 295-315.

21. Heatherton T.F., Baumeister R.F. Binge eating as escape from self-awareness // Psychol. Bull.- 1991.— Vol. 110(1).— P. 86-108.

22. Данильченко Т.В. Особливості формування першого враження // Соціальна психологія. - 2004. - № 3(5). - c.132-144.

23. Istvan J., Zavela K., Weidner G. Body weight and psychological distress // International Journal of Obesity. 1992. Vol. 16(12). P. 999-1003.

24. Савчикова Ю.Л. Психологические особенности женщин с проблемой веса: дисс. канд. психол. наук. СПб., 2005 


\title{
Main tendencies in modern psychology
}

\author{
Elena Shopsha ${ }^{1}$, Tatiana Vakulich ${ }^{2}$ \\ IAPM, Kyiv, Ukraine
}

\begin{abstract}
Introduction. With the development of psychology as a science, with usage of psychological knowledge in various fields of human activity specific field of knowledge gradually became isolated and independent. Each of the areas of psychological knowledge has certain objects and methods of study peculiarities of mental activity depending on the conditions in a particular area of human life and activities... However, all areas of psychological knowledge require knowledge of psychology that studies the psychology of methodological issues, the nature of psychological phenomena, patterns of development and progression of cognitive psychological processes.
\end{abstract}

Purpose of this article is to highlight main tendencies in modern psychology development

Results. The last two centuries the development of psychology is closely related with achievement of philosophical thought and progress of science. Materialist interpretation of nature and the nature of mental phenomena has caused the appearance of dialectical materialism philosophy and the development of the doctrine about the reflex nature of the psyche. The basic principles in the national psychology are the principles of integrity mental life of the individual, the relationship between the mental processes and the properties of the individual in learning and education, social conditioning of mental life

Conclusions. There are two-way of communication between the psychology and other sciences: in some cases, the psychology uses the knowledge of other sciences to solve the problems, in other cases -the other science uses psychological knowledge to explain or resolve certain issues.

Keywords. Psychology, behaviorism, psychoanalyses, cognitive psychology

Introduction. With the development of psychology as a science, with usage of psychological knowledge in various fields of human activity specific field of knowledge gradually became isolated and independent.

There are general psychology, age, educational, social, genetic, engineering, military, medical, legal, sports. Comparative psychology, industrial psychology, art, pathopsychology. Due to space flight appeared a special branch of psychology - cosmic psychology. 
Each of these areas of psychological knowledge has certain objects and methods of study peculiarities of mental activity depending on the conditions in a particular area of human life and activities, and their claims to moral and psychological qualities of the individual. However, all areas of psychological knowledge require knowledge of psychology that studies the psychology of methodological issues, the nature of psychological phenomena, patterns of development and progression of cognitive psychological processes, individual characteristics of the human psyche, her feelings and will, temperament, character and ability. In an age of scientific and technological progress and social psychologists were attracted by the problems Labour Psychology and Social Psychology.

Purpose of this article is to highlight main tendencies in modern psychology development

Main results. The last two centuries the development of psychology is closely related with achievement of philosophical thought and progress of science. Materialist interpretation of nature and the nature of mental phenomena has caused the appearance of dialectical materialism philosophy and the development of the doctrine about the reflex nature of the psyche (Maksymenko, 2008). The philosophy of pragmatism had led to behaviorism in American psychology or behavioral science (Crossley, 2009). German psychologists M. Vertheymer, W. Keller, K. Koffka, K. Lewin put forward the idea of structural psychology on the basics of special studies. The main points were to recognize the primary primate structure, integral formations which define properties and functions separate parts that make up an integrated mental activity. Research in psychopathology and psychiatry necessitated to study the role and effect of unconscious factors that determine the needs and desires of the individual and its behavior. This resulted the psychoanalytic tendency in psychology ( $Z$. Freud) (Frankl, 2018).

Behaviorism denies the consciousness as a subject of psychology. The subject of behaviorism is the study of behavior as external reactions of the body to stimul. Behavior, according to behaviorists, formed as a result of unconscious selection of physical movements as reactions to stimuli. The most important in the behavior - are skills. Thinking is refered by behaviorists to speech and language skills. The leading point in the study they consider training, during which the necessary skills are acquired, herewith understanding of purpose, content and process of learning underestimated.

The basic principle of the structural psychology is the integrity of mental activity that is not the sum of individual mental processes, but the specific structure with inherent of 
specific properties in it which are not derived from the properties of individual elements of mental life. On the contrary, the properties of the structure as a whole determine the properties of its individual elements. Psychoanalysis closely related to Freud's theory of the prevalence of mental activity of the individual unconscious, instinctive inclinations. According to psychoanalysts, the source of human activity is a deeply instinctive, biologically determined aspirations. This aspiration penetrates from the subconsciousness to the consciousness, becoming a source of human activity, originally directed the actions and behavior. The particular importance psychoanalysts have about the sexual attraction. The basic principles in the national psychology are the principles of integrity mental life of the individual, the relationship between the mental processes and the properties of the individual in learning and education, social conditioning of mental life.

\section{Cognitive mental processes of the individual.}

Cognitive activity - a process reflected in human brain objects and phenomena. Displaying reality in human consciousness may occur at the level of sensory and abstract knowledge. Sensory perception characterized in that the objects and phenomena of the objective world directly act on the senses of man - his sight, hearing, smell, tactile and other analyzers and appear in cord. This form of understanding reality are cognitive mental processes of sensation and perception. The impression produced by sensations and perceptions, carry information about the external characteristics and properties of objects, creating a sensual experience of man. The highest form of man's knowledge of reality is an abstract knowledge of what is going on with the processes of thinking and the imagination. In the developed form of these cognitive processes unique to the person who has the mind and mental activity reveals activity. The essential feature of thought and imagination is the indirect nature reflect their reality, due to the use of previously acquired knowledge, experience, opinions, construction of hypotheses and so on. The object of knowledge in the processes of thinking and imagination are internal, not directly data in sensations properties of objects, patterns of phenomena and processes. Important role in human cognitive activity plays a memory that uniquely reflects, captures and reproduces what appears in consciousness in the process of learning.

An important feature of cognitive activity is emotional and volitional processes that motivate a person to action, volitional acts. Knowledge objects and phenomena of objective reality, mental life is all cognitive processes. The basis for intellectual knowledge of the world, no matter how difficult it was, is perceptual knowledge. However, perception, 
memory, reproduction and other processes are not possible without the participation of mental activity, emotions and volitional intentions. But each of these processes has certain laws and acts the mental activity or as a top or as a subsidiary.

Feeling - cognitive mental process mapping in the human brain specific properties of objects and phenomena in their direct effects on the senses of man. The feeling - this is the easiest mental process, the primary form of orientation of a living organism in the environment. Begins with a sense of human cognitive activity. Using different analyzers it selects, accumulates information about the objective reality of their own subjective states and on the basis of received impressions produces adequate conditions of ways to respond to internal and external influences (Seligman, 2002). Sense organs - the only channels through which the outside world enters the mind of man. Reflecting the objective properties of objects and phenomena that exist in the sense of consciousness as a subjective image of the objective world. This feature sensations caused, on the one hand, the most natural feeling as the product reflectance of the brain, and the other - the mental structure of personality that feels. For the typical feelings of positive or negative emotional connotation. Pleasant or unpleasant feelings signal a positive or negative effect of stimulus and cause the appropriate action on it. The vital role of Gnostic and feelings are very important because they are the only source of our knowledge of the external world and about ourselves.

\section{Physiological basis of feelings.}

The doctrine of higher nervous activity reveals the scientific foundations of natural feelings. IM Sechenov and Pavlov for his research showed that feeling - a kind of reflex action, which is the physiological basis for neural processes that occur as a result of the influence of stimuli on the senses or analyzers. Analyzer - the authority of animal, including human, body, analyzing the surrounding reality and distinguish it certain types of energy: visual analyzer isolates light energy or vibrations of electromagnetic waves, hearing - the sounds, ie fluctuations in air gustatory, olfactory - chemical properties of substances, skin thermal and mechanical properties of objects and phenomena that cause certain sensations. Each analyzer is peripheral, analyzing part, or receptor, ie sensory organ, the purpose of which is the separation of the surrounding reality, light, sound, smell and other properties. The other part of it - leading the way from the receptor to central analyzer, located in the brain. In the central part of the analyzer distinguish its core, clusters of sensory cells, and scattered off the cages. The core of the analyzer, as noted by Pavlov (Schneider, Längle, 2012), provides a subtle analysis and synthesis of excitations coming from the receptor. This 
allows stimuli differentiated by features, quality and intensity. Scattered cells perform a rough analysis of such a distinguished musical sounds from noise, perform fuzzy distinction of colors, smells.

Organic violation of any part of the analyzer - peripheral, or central leadership - or cause blindness or deafness, or loss of smell, taste, etc., depending on which analyzer violated. If disturbed only the central part of the analyzer, there is a lack of understanding of what they heard and saw, although feeling a light or sound. Physiological basis simplest sensations and sensitivity in the early stages of life is definitely innate reflex activity of the nervous system. More complex feelings are caused by conditional reflex analytic-synthetic activity of the brain.

Conclusions. There are two-way of communication between the psychology and other sciences: in some cases, the psychology uses the knowledge of other sciences to solve the problems, in other cases -the other science uses psychological knowledge to explain or resolve certain issues.

Intersubjective communication of psychology and other sciences contribute to their mutual development and application in practice. Psychology contributes to the development of data based on biology, including anatomy and physiology, the study of higher nervous activity. In turn, the psychological data are widely used in medicine, particularly in psychiatry

\section{References}

1. Frankl, V. (2018). The Doctor and the Soul: From Psychotherapy to Logotherapy. Kharkiv: Family Leisure Club. (In Ukrainian)

2. Maksymenko, S. D. (2008). Generic psychology. (изд. 3rd). Kyiv: Center of educational literature

3. Michele L. Crossley. (2009). Introducing narrative psychology. Philadelfia: Open University Press

4. Schneider K, Längle A (2012) The renewal of humanism in psychotherapy: Summary and conclusion. Psychotherapy, 49 (4), 480-481

5. Seligman, M. (2002). Positive psychology, positive prevention, and positive therapy. In 6. Snyder \& S. Lopez (Eds). Handbook of positive psychology. New York: Oxford, 3-9

(C) NDSAN (MFC - coordinator of the NDSAN), Italy, 2019 
Features of the emotional-volitional sphere of persons with vascular diseases of the brain

\title{
Особенности эмоционально-волевой сферы лиц с сосудистыми заболеваниями головного мозга
}

\author{
Руслана Белоус Ruslana Bilous
}

Кременчугский национальный университет имени Михаила Остроградского, Кременчуг, Украина

\begin{abstract}
.
Introduction. In crisis conditions of the development of society, the problem of improving the quality of life of people with chronic somatic diseases is being updated, which requires improving not only treatment methods, but also rehabilitation, psychological support for patients.

Purpose. The aim of the study was to identify the characteristics of the emotional-volitional sphere of stroke patients with the subsequent development and implementation of a training and recovery program

PracticallSocial Value. Partial restoration of the emotional-volitional sphere of stroke patients will help them recover faster, and the acquisition of self-regulation skills will delay the occurrence of the following, which will improve the quality of life

Conclusions. The study revealed the characteristics of the emotional-volitional sphere of stroke insects, which allowed us to develop a training and recovery program to relieve the symptoms that arose. The significant problems of this conditions are an unsatisfactory level of neuropsychic resistance, high levels of situational and personal anxiety, aggressiveness and hostility
\end{abstract}

Keywords. emotional-volitional sphere, stroke, anxiety, neuropsychic resistance, aggressiveness

Introduction. В кризисных условиях развития общества актуализируется проблема улучшения качества жизни людей из хроническими соматическими заболеваниями, что требует совершенствования не только методов лечения, но и реабилитации, психологической поддержки больных. Болезни системы кровообращения на Украине в общей структуре заболеваний существенны с тенденцией до возрастания $(80,8 \%$ среди всего населения). Согласно статистическим исследованиям 28,9 \% взрослого населения и 20,2 \% в трудоспособном возрасте входят в структуры первичной инвалидности по заболеваниям сердечно-сосудистой системы. На каждые 100 млн. жителей приходится примерно 500 тыс. инсультов и церебральных сосудистых кризисов на год, смертность от которых составляет (данные ВООЗ) 12-15 \% общей смертности населения. Поэтому попросы психологического сопровождения, профилактики и лечения сосудистых заболеваний нервной системы социально значимы. Симптоматическое лечение не всегда результативно. Болезни обостряются вследствии значительных эмоциональных переживаний. Поэтому возникает необходимость всестороннего анализа причин возникновения и развития заболеваний, рассмотрения личности в единстве ее сосматического и 
психологического состояний. Следует отметить в даном контексте значение психосоматической теории возникновения заболеваний (Ф. Александер, Ф. Бассин, В. Райх, М. Фридман, Дж. Энджел), в которой подчеркивалось единство тела и психики с акцентом на «патологии отношений», но и сейчас психологическим факторам возникновения и развития заболеваний уделяется недостаточно внимания

Purpose. Целью исследования было выявление особенностей эмоциональноволевой сферы больных на инсульт с последующей разработкой и внедрением тренингово-восстановительной программы.

Methodology. Исследование проводилось в Украине в течение 2018-2010 гг. Обследовано 75 больных Кременчугской городской больницы № 1 имени О. Богаевского с диагнозом острое нарушение мозгового кровообращения в среднем на $8(+2)$ сутки заболевания. Средний возраст пациентов составил 38,1 лет; 37 \% имели высшее образование, 33 \% среднее профессиональное; среднее и неполное среднее соответственно 23 \% и 7 \%. Для исследования уровня нервно-психической стойкости больных была выбрана методика «Прогноз» В. Бодрова, уровня тревожности - методика Ч. Спиблергера (адаптация Ю. Ханина), уровней агресии и враждебности - методика БассаДарки.

Results and Discussion. Результаты исследования показали высокий уровень нервно-психической стойкости у 14, 3 \% больных, достаточный у $26 \%$, удовлетворительный у $43 \%$ и неудовлетворительный у $16,7 \%$ пациентов при наличии высокого уровня ситуативной тревожности у 28,6 \% пациентов, среднего у 48,4 \%; личностная тревожность составила $43 \%$ высокий уровень, $23 \%$ - средний и 34 - низкий; высокая агрессивность наблюдалась у 54, 3 \% больных, высокая враждебность у 43 \%, что обусловило разработку тренингово-восстановительной программы для пациентов неврологического стационара. Обобщение результатов констатирующего эксперимента выявило 18 испытуемых, которые и составили экспериментальную группу. В результате реализации данной программы и сравнения исследуемых контрольной и экспериментальной групп после тренинга, значительных отличий в уровнях агрессии, ситуативной тревожности, нервно-психической стойкости за критерием Пирсона выявлено не было. При этом высокий уровень агрессии снизился на 17,5 \%, ситуативная тревожность на 43,3 \%, что подтверждает эффективность разработанной тренинговой программы.

PracticallSocial value. Частичное восстановление эмоционально-волевой сферы инсультных больных поможет им быстрее выздоравливать, а обретение навыков саморегуляции отсрочит возникновение следующего, что позволит улучшить качество жизни.

Conclusions. Исследование выявило особенности эмоционально-волевой сферы инсультников, что позволило разработать тренингововосстановительную программу по снятию возникших симптомов. Характерными проблемами данного состояния есть неудовлетворительный уровень нервно-психической стойкости при наличии высоких уровней ситуативной и личностной тревожности, агрессивности и враждебности

Keywords. эмоционально-волевая сфера, инсульт, тревожность, нервно- 
психическая стойкость, агрессивность

\section{References.}

1. Багамет Е. М. Психотерапія в клінічній практиці / Е. М. Багамет, В. М. Сухоруков, І. 3. Вельвовскім, Н. К. Липгарт. - К. : Здоров'я, 1984. - 160 с.

2. Бачинская Н. Ю. Синдром умеренных когнитивных нарушений / Н. Ю. Бачинская // Журн. НейроNews: психоневрология и нейропсихиатрия. 2010. - № 2/1. - С. 12-17.

3. Бодров В. А. Роль личностных особенностей в развитии психологического стресса / В. А. Бодров // Психические состояния. Хрестоматия ; сост. и общая редакция Л. В. Куликова. - СПб. : Питер, 2001. - C. $448-454$.

4. Куликов В. Г. Психогигиена личности. Вопросы психологической устойчивости и психопрофилактики / В. Г. Куликов. - СПб. : Питер, 2004.$464 \mathrm{c}$.

5. Мілютіна К. Форми психокорекційного впливу / К. Мілютіна. - К. : ГЛАВНИК, 2007. - 143 с.

6. Психиатрия, психосоматика, психотерапія / К. П. Кискер, Г. Фрайбергер, Г. К. Розе, Э. Вульф ; пер с нем. И. Я. Сапожниковой, Э. Л. Гушанского. - М. : Алетейа, 1999. - 504 с.

(C) NDSAN (MFC - coordinator of the NDSAN), Italy, 2019 


\title{
Conscious Choice of a Healthy Lifestyle as a
}

\section{Manifestation of Safe Personal Behavior in Adulthood}

\author{
Antonina Kononchuk ${ }^{1}$, Tetyana Svatenkova ${ }^{2}$, \\ Oleksandr Svatenkov ${ }^{3}$, Danylo Kononchuk ${ }^{4}$ \\ Mykola Gogol Nizhyn State University, Nizhyn, Ukraine
}

Background. Healthy living as a way of life is aimed at preserving and improving people's health. It is one of the strategic vectors for the development of Ukrainian society. The formation of a healthy lifestyle occurs in the process of socialization of the individual, through a purposeful and conscious process of creating a person's own life-support system, which is based on a responsible attitude to their health.

Particularly relevant is the problem of healthy lifestyles of the individual in adulthood, as young people form a group that is prone to negative environmental influences due to lack of value orientations and lack of experience. The list of lifethreatening and health-promoting factors for young people is impressive and threatening. $40 \%$ of boys and $30 \%$ of girls use alcohol regularly, $10 \%$ of teenagers try drugs, $32.8 \%$ of teenagers for every 100,000 people commit suicide. Depression causes $60 \%$ of youth suicides. $82 \%$ of boys and $72 \%$ of girls have smoking experience under the age of 18 (O.O. Seleznyova, 2019, O.Jaremenko, O.Vakulenko, Yu. Galustyan, 2004).

These factors determine the need for safe behavior among young people, where a healthy lifestyle is an indicator of a responsible attitude to one's life and health.

Purpose. Identify and analyze the characteristics of healthy lifestyles of young people as a manifestation of the formation of their safe behavior.

Methods. We applied theoretical methods: analysis of scientific literature, documents, synthesis, comparison and synthesis of data when studying this problem. We conducted a survey and used interviewing, observation, mathematical statistics methods to identify the characteristics of healthy youth lifestyles and their relationship with safe behavior.

Results. The philosophical works of V. Petlenko, L. Suschenko, G. Tsaregorodtsev and others are covered in the paper on the essence of health problems and various aspects of a healthy lifestyle; in medical researches of $\mathrm{M}$. Amosov, I. Brehman, Y. Lysitsyn, A. Sakhno and others; in social and pedagogical - O. Balakireva, O. Vakulenko, L. Zhalilo, N. Komarova, B. Raina, O. Yaremenko and others. Psychological-pedagogical and social aspects of forming healthy lifestyles of children and youth are characterized in the studies of O. Bezpalko, O. Dubogay, N. Zaveryko, I. Zvereva, N. Zimivets, A. Kapska, G. Laktionova, S. Omelchenko, V. Petrovich, S. Strashko, F. Filatov, E. Fromm and others.

Scientists treat health on the basis of a comprehensive approach as "... the dynamic state of complete physical, spiritual, psychological, intellectual, social well-being, and not just the absence of disease or physical disabilities based on 
the definition of WHA" health "(I.D. Zvereva, 2012). There are its corresponding components: physical, spiritual, psychological, intellectual, social (V. Ananiev, I. Brehman, O. Vasilyeva, G. Nikiforov, B. Rein, F. Filatov, E. Fromm).

A healthy lifestyle is a system of thought, activity and behavior that is purposeful and serves the well-being of all components of health. In fact, it manifests itself in a way of life that a person consciously chooses and reproduces in everyday life in order to preserve and promote health, to understand its value for one's life and to be responsible for one's actions in the context of harm to one's own health and the health of others. This lifestyle and attitude towards one's self and surroundings characterizes the formation of personal behavior as safe.

The problem of safe behavior of young people is caused by difficult life circumstances, irresponsible attitude to their health, their actions, lack of necessary information or its unreliability, negative phenomena in the youth environment. The research of this problem by scientists T. Alekseenko, R. Vainola, M. Vasilyev, N. Zaveriko, S. Kushnaryov, V. Latchuk, N. Liz, Yu.Naumenko, A. Popkov, L. Sidorchuk, M. Snitko and others has allowed to characterize safe behavior as "behavior that reflects a person's responsible attitude to his life and the consequences of his actions and actions in different life situations and in different environments" (T.F. Alekseenko, 2009). The manifestations of safe behavior are: healthy lifestyles, absence of various addictions, bad habits, avoiding life-threatening and health situations, adherence to social norms. Social institutes are areas of formation and acquisition of experience of safe behavior of the person. Among social institutes, we distinguish higher education institutions. The immediate task for higher education institutions is to foster a responsible attitude of young people to their health, the health of others, the formation of the need for self-knowledge, self-improvement of physical, mental and mental abilities.

Experimental work was carried out with the student youth of Nizhyn, Chernihiv region. The students of the higher educational establishments of the city made a sample, namely: Nizhyn Mykola Gogol State University, Nizhyn Agrotechnical Institute, Nizhyn City School of Culture and Arts named after Maria Zankovetsky and Nizhyn Medical College. There were 688 subjects studied, of which 210 were boys and 478 were girls. We analyzed the respondents' answers to the questionnaire. The questions were aimed at studying the students' opinions regarding understanding of the essence of a healthy lifestyle, factors influencing the process of forming a healthy lifestyle and safe behavior, awareness of the importance of this problem in comparison with other social problems, etc.

The data obtained indicate that, "Do you think your lifestyle contributes to maintaining your health?" we have the following results:

- 398 respondents said that their lifestyle contributes to maintaining health;

- 100 respondents believe that their lifestyle is not conducive to health,

- the rest chose the "hard to answer" option. In our opinion, this answer is closer to the no answer.

Thus, it can be assumed that almost $59 \%$ of the students in Nizhyn are implementing a healthy lifestyle.

The results of the respondents' answers to the question: "For you, health is..." showed that the student youth of Nizhyn adhere to the most comprehensive definition in their understanding of health, which is enshrined in the scientific literature on this subject (67.7\% of respondents) ). This understanding of the 
meaning of the concept of "health" by student youth is one of the factors that influence the formation of a healthy lifestyle. Thus, it can be argued that the correct understanding of the content of the concept of "health" by students is one of the factors that determine the success of higher education institutions in shaping a healthy lifestyle. These can also include the value orientations of young people in fashion, the influence of the factors of socialization of meso- (social policy of the state, mass media, etc.) and microlevel (family, peer groups, teachers, etc.), activities of state and non-governmental institutions and organizations. In particular, one of the determining factors in this list is youth fashion. The question was asked to find out its place in the life of student youth: "Do you think that among peers today there is a fashion for: ...".

Respondents were offered seven options to answer this question, namely: "cool" clothing, smoking, drinking, sexual experience, playing sports, drug use, tattooing. Respondents were able to choose several answer options according to the instructions, so the total percentage exceeded $100 \%$. The largest number of respondents - $366(53.2 \%)$ - said that today among young people there is a fashion for "cool" clothes. 327 (47.5\%) of those polled said that there is a fashion for smoking among modern youth, and 250 (36.3\%) to drink alcohol. In addition, 43 (6.3\%) respondents indicated that there was a fashion for drug use in the youth environment.

$224(32.6 \%)$ respondents indicated that sport is one of the trends of modern students as opposed to previous answers. It is interesting that the opinion of girls in general coincides with the data presented above, while boys are the most fashionable are sports (97 respondents - 46.2\%) and smoking (99 - 47.1\%). "Cool" men's clothing is only in third place in the ranking. Thus, we can conclude that youth fashion is a significant factor in shaping student lifestyles.

We asked the question: "To what extent do you personally care about these social problems?" (the list was more than 20 options) to determine the importance of a healthy lifestyle to student youth compared to other social problems. Additional calculations were introduced to process the results. This way of working with the data made it possible to obtain a numerical expression of the respondents' answers for each of these social problems. This determined its place in the overall ranking. Unfortunately, the healthy lifestyle issue ranked only eighth in this rating. The issues that are directly related to a healthy lifestyle are:

alcohol abuse among youth - 11th;

the spread of smoking among young people - 16th place;

insufficient opportunities for sports - 18th place;

low awareness of healthy lifestyles - 19th out of 21 of the social problems mentioned in the questionnaire.

It should also be noted that there are no significant differences in boys 'and girls' responses. Spearman's rank correlation coefficient for them is 0.75 .

The family remains a powerful social institution in the fields of education and health. This is a testament to the range of people students talk to about the issues they are most concerned about. All this is objectively related to the full or partial financial dependence of the students on the parental family and subjectively - with the importance and peculiarities of family upbringing, parental authority, traditions of Ukrainian ethnicity.

Peers have a leading role in the issues of safe behavior, gender relations, puberty, and the intimate life of contemporary students. These are the traditional spheres of 
youth influence on each other. This way of interaction and transfer of experience is related to the assimilation and reproduction of social norms, values, behaviors and relationships inherent in the youth subculture. This is especially evident in the psychological content of the leading activities of this age - communication with peers and mastering adulthood. After all, responsibility for one's choice, one's own actions, one's choice of vector of professional strategy and life perspective, lifestyle are all important components of adulthood.

The state has a real basis for the implementation in the educational sphere of the tasks of preserving and promoting the health of student youth by creating positive motivation for the conscious choice of a healthy life organization style - this has proved the study of the current legal framework in Ukraine shaping the health of the young generation.

Theoretical analysis of problems of formation of student's health in the period of university education, young people show that the level of study of the problem does not provide a sufficiently substantiated explanation of a number of phenomena that arise during the acquisition of educational information on preservation and promotion of health, in particular in the process of valeological education and upbringing. One of them is a kind of cognitive-behavioral dissonance: despite subjective prerequisites (high academic success, uncritical acceptance of healthy lifestyle samples, etc.), students' activities do not meet the principles of health formation, do not provide sufficient level of their activity in choosing healthy style organization of life.

There is much that can be done to build mental endurance early to prevent mental disorders and illness among teens and young people, and to control these ailments and restore health. Prevention begins with the knowledge and understanding of the first signs and symptoms of mental illness. Parents and teachers can help shape the life skills that children and adolescents need to overcome everyday difficulties at home and at school. Psychosocial support can be provided in schools and other community levels. It is also advisable to organize, improve or extend the training of health care professionals to identify and manage mental disorders.

Communication, interaction with friends, family play a decisive role in shaping healthy student life, safe behavior skills. Student youth are aware of the value of health, to a certain extent, the desire to lead a healthy lifestyle, but this is often hampered by a variety of social problems that relay in each individual's individual life situation. Based on the above, we believe that a prerequisite for the formation of motivation for a healthy lifestyle and safe behavior of student youth is the attitude to their health as an important vital value. Therefore, the development and implementation of innovative methods and forms of educational work in higher education institutions in this area, we determine the appropriate strategy for improving the health of young people. It is with this aspect that we connect the prospects of further exploration of the problem of healthy lifestyles and the formation of safe behavior of modern students.

Conclusion. The article examines the features of healthy lifestyle of young people at the stage of higher education institution as a manifestation of their safe behavior. The interconnection of health, healthy lifestyles and the formation of safe personal behavior are revealed. 
Keywords. Health, youth, healthy lifestyles, safe behavior.

\section{References}

1. Alekseenko, T. (Ed.). (2009). Social pedagogy: a dictionary. Vinnytsia:

Planer.

2. Husak, P. (Ed.). (2009). Health Responsibility: Theory and Technology: A Monograph. Lutsk: OJSC "Volyn Regional Printing House".

3. Romanova, N.F. (2010). Shaping healthy lifestyles as a modern strategy for combating socially dangerous diseases among children and young people: Monograph / ed. T.V. Semigina .- K .: Pulsary.

4. Selezneva, O.O. (2019). Youth Health and Healthy Lifestyle Formation /https://www.narodnaosvita.kiev.ua/?page

5. Svatenkova T.I., Svatenkov O.V. (2018). Modern tendencies of ecological education of preschool children: foreign experience. SOCIAL WORK \& EDUCATION.Scientific Papers, Vol. 5, No 1, ISSN (Online): 2520-6230 ISSN (Print): 2520-6451

6. Svatenkova, T.I. (2018). Development of emotional intelligence of a child. The experience of practical psychologist. SIA OmniScriptum Publishing, Brivibas gatve 1 97, LV-103 9 Riga, Latvia, - 140p. ISBN: 978-613-9-94000-4

7. Yaremenko, O., Vakulenko, O., Galustyan, Y. and others. (2004). Creating a healthy lifestyle for young people: a strategy for the development of Ukrainian society. Kyiv: State Institute for Family and Youth Issues, Ukrainian Institute for Social Research.

8. Zvereva, I.D. (2012). Encyclopedia for specialists in the social sphere - Kiev,

Simferopol: Universum

(C) NDSAN (MFC - coordinator of the NDSAN), Italy, 2019 


\title{
PSYCHOLOGICAL CONDITION OF GRIEVING FAMILY MEMBERS AND
} THEIR RESOCIALIZATION

\author{
Olena Kostyuk ${ }^{1}$, Olena.Boychuk ${ }^{2}$ \\ ${ }^{1}$ P.L Shupyk National Medical Academy of Postgraduate Education, National University of \\ "Kyiv Mohyla Academy", Kyiv, Ukraine \\ ${ }^{2}$ National University of "Kyiv Mohyla Academy", Vadym Hetman Kyiv National Economic \\ University, Kyiv, Ukraine
}

Introduction. Personal development in competitive and adverse conditions gives us plenty of examples that show negative behavior and incapability of making peace between nations. The situation in the world today confirms the previous statement, Ukraine suffers more than many other countries because of the powerful neighbor from the East who forces our country to accept his conditions. The war in Eastern Ukraine is the consequence of this irrational and atavistic tendency. We are the victims of the aggravation between two dialectic processes of social activism: disconnection (destructive situations, ATO, loss of a family member, family break up, heightened level of aggression in the community) connection (constructive and creative appearances, adaptation in conditions of forced immigration, posttraumatic growth, resocialization after overcoming trauma, tendency for reconciliation, personal growth in a new profession).

This is the reality that requires psychological science and practice to find quick and accurate answers because the goal is to save people's mental health in military and mobilization conditions.

Purpose. The main goal of the research is to generalize the information about psychological features of the people who have experienced loss. Also to spot the stages of women's post-loss resocialization and factors that have a positive impact on that resocialization.

Methodology. The authors of this paper made research on the psychological features of the people who have experienced loss due to military situation in the East of Ukraine and who need psychotherapy to help the process of resocialization. The facts stated in the paper that helped to analyze the situation were received during work in the period of 2015-2018 at the center of psychosocial rehabilitation at National University of "Kyiv Mohyla Academy". 5370 people have addressed to the center to get help during this period. 1414 of them have gotten individual consultations, 3953 have participated in group therapies. The gender phenomena was discovered, women address for help more than men. We have also analyzed and classified the reasons that make people address for help and discovered the levels of impact caused by loss. The paper also presents the methods that the center uses in their work.

In the past three years, we have created 3 special groups of psychotherapy for those people who have faced loss, each group had about 6-8 meetings. One third of those who have gone through individual and group therapy also took part in stabilizing group events of our center, like " Magic of breathing", "Soma-relax", "Right hemisphere drawing" or "Mandala therapy", patients visited our playback theater and also came for a consult because of problems with children. 
We used CETA: Common Elements Treatment Approach, the program that has two forms of psychotherapy, a short-term with 5 sessions, middle term with 8-12 sessions. CETA uses cognitive behavioral therapy methods and is lead by the JHU Applied Mental Health Research group. We made a screening research on women who had psychotherapy to monitor their condition, the screening was made with the help of "mental health quiz КМА-УДХ). The screener was received from the JHU Applied Mental Health Research Group and adapted for use in Ukraine by the employees of National University of "Kyiv Mohyla Akademy" Psycho-social Rehabilitation Center.

Results. While observing the process of secondary socialization after loss we can state that it has two stages.

The first stage is desocialization, it is the opposite to socialization, this part of the process is based on the fact that women need to change their social role, from wife to widow. Women have to reject their previous gender-role model as mother, wife, housewife, employee, her habits and skills to make a transition to a new stage because those usual roles become impossible or divergent in a new status.

We have often observed total or almost total social isolation, minimization of action that only maintains life in family or work system on the smallest level.

Many patients give up on their social interactions and opportunities, their faith, ideology, life values change completely. They experience a full range of reactions from devaluation of their personality, their life and life of their closest people to devaluation of life in general, micro and macro-social environment of a widow or a mother who lost her child.

Psycho-emotional condition of women experiences many changes, they avoid joy and feel constant pressure, they try to come back to grief again but in a new symbolic status.

The next stage is resocialization. The moment when women come back to their usual life but in new circumstances resocialization happens. It can be either under social pressure or because of inner desire.

Conclusions. Our experience that is based on individual and group psychotherapy shows that resocialization starts under pressure, women have to come back to their work and duties because of needs.

Social stigmatization of widows and mothers who lost their children on war leads to creating new social communities where women have support and comfort, where they feel unity. After this women enter a different stage of socialization, many of them change the social environment or job, life position and some aspects of their personality.

This way we consider desocialization and resocialization as parts of the socialization process, to be specific "secondary socialization". It occurs after a serious loss of someone close and requires a significant overview of old social habits and functions. Society plays an important role in secondary socialization process: nation, family, and environment.

The results of the research stated in this paper we recommend to spread around and use in practice. Also, there are created different suggestions on how to improve the quality and success of resocialization.

1. On the government level

To refine the government politic about supporting families who lost their closest 
people.

Social advertisement that honors the lives of the dead. Advertise that sets a healthy relationship with the family who lost their beloved people, not stigmatizing one.

Adding a ritual of honoring the lives of the fallen to national celebrations and important dates.

Creating the virtual memory book of the dead by the Ministry of Defence.

2. On the mass level.

Rituals of honoring the memory of the dead and their families.

Non-formal support. Creating support groups that can help to compensate lost opportunities or to fight social isolation, etc. also different kinds of support on the micro-social level can be helpful.

Formation of specific moral and ethical principles that can help to build a healthier and stronger relationship with those families who lost one of their closest people.

Social flash-mobs like "join mom of your lost friend for a tea", "be a Santa Claus for your dead's friend children", "share the warmth of your heart", "teach a son of your dead friend how to play football or how to drive a nail".

3.On the professional level.

All widows and parents of the dead ATO members need to have a right for professional, prolonged, free of charge help in psycho-social rehabilitation centers.

For those specialists who work with the mentioned type of clients have been created specific supervising systems that prevent emotional burnout.

Special analytical and monitoring systems created in order to know the effectiveness of the treatment.

Methodical and educational training centers for psychologists who specialize on crisis.

Resocialization of those who have faced military loss has to stop being just a personal problem, it is a problem of a nation and by participating in this process we help to overcome desocialization and save the mental health of the nation and its humanization

Keywords. military losses, mental effects, types of lesions, gender characteristics, means of assistance and re-socialization 
Art and psychosis: Elements of psychopathology in the work of Edgar Allan Poe. The case of tale tell heart

Evangelos Fradelos

Psychiatric Department, Athens General Hospital of Chest Diseases, Athens Greece

University of Thessaly, Larisa, Greece

\begin{abstract}
.
Since the depths of time up until nowadays arts can one say that reveals our unconscious, mental state, depicts our hopes and fears as well as shapes our expectations. In literature we can say that mental illness and writers are accompanied each other since ages as they write from a personal perspective or a socially conscious one. This paper is to reveal elements of psychiatric symptomatology in the main character and narrator of The tale tell heart of Poe and to answer what types of symptoms is the narrator experiencing. In this study a qualitative descriptive methodology is employed in order to answer the main research question. The main character of the novel is experiencing symptoms such as auditory hallucinations, delusional ideas and more. The behavior and mental state of the narrator is escalating through the text and finally commits an unspeakable crime. By examine the depictions of psychiatric illness in the literature and arts in general of a specific period of time enlights the beliefs and the perception that people of such time had on mental illness and patients in such way help us to understand the evolution of stigma and stigmatizing behaviors through time
\end{abstract}

(C) NDSAN (MFC - coordinator of the NDSAN), Italy, 2019 


\title{
Training in the restoration of communication skills of the individual "Way Home" \\ Тренінг 3 відновлення комунікативних навичок особистості “Дорога додому" \\ Nadiia Golembievska \\ National Academy under the President of Ukraine, Kyiv, Ukraine \\ Національна Академія при президентові України, Київ, Україна
}

\begin{abstract}
. В статті висвітлено один із елементів програм соціальнопсихологічної адаптації, що склали інструментальну базу під час розгортання антикризових заходів в період 2014-2018 років. В запропонованому до розгляду описі тренінгу основні акценти уваги сфокусовані на загальнодержавних аспектах проблематики соціальної адаптації демобілізованих учасників бойових дій та висвітленні переважних підходів щодо психологічних методів та методик задля відновлення комунікативних навичок учасників бойових дій та членів їх родин як шляху до вирішення цих проблем.
\end{abstract}

Ключові слова: моделі сприймання; психічне здоров'я; нейробіологічний вплив; есхатологічне окреслення; програми; абілітація; декомпресія; діагностичний комплекс; адаптація; реабілітація; громадська охорона здоров'я; комунікативні навички; персональна дефіцитарність; Mental Heals; Public Health as a system; арт-терапія; академічна мобільність.

Проблема та її актуальність: Відсутність професійної та соціальної інфраструктури для застосування міждисциплінарного підходу в системі охорони психічного здоров'я (Mental Heals) набула в Україні кризових ознак, попри наявність грунтовних розробок в цій сфері. Наприклад, ретельно досліджені шляхи та створена концепція побудови Громадської охорони здоров'я (Public Health as a system) як системи науково-практичних заходів не медичного та медичного характеру [2, ст.161]. Окремого наголосу в цьому контексті набув аспект створення умов для збереження та відновлення здоров'я зусиллями громадських спільнот, адже сьогодні, як ніколи раніше, ознаки есхатологічного окреслення зовнішніх викликів зобов'язують нас застосовувати допоміжні щодо психіки людини й природнього середовища методи створення цієї системи як визначального елементу публічного простору.

Методологія. Сьогодні в Україні фахівці зазначають “гіпердіагностику посттравматичних стресових розладів і гіподіагностику гострих стресових реакцій” [1]. Арт-терапевтичні методики, які ми використовуємо в цьому тренінгу, довели свою практичну значущість завдяки широкому визнанню насамперед в реабілітаційних заходах. Адже відомо, що синхронізація роботи різних відділів мозку торована через локальну активацію дрібної моторики, внаслідок чого відчутно знижується гострота проявів тих чи інших реакцій і змінюються ознаки відчуттів, а також ефективні при лікуванні переживань, пов'язаних із “інтрузивним відіграванням" травматичного досвіду [3, ст. 68]. В якості образотворчої компоненти тренінгу ми запропонували одну 3 традиційних для архаїчної моделі сприймання: “крапочкове письмо”, з огляду на прості методи створення композицій та легкість досягнення позитивного забарвлення емоційного стану суб'єкту. Ця техніка має безліч вузькоспеціалізованих переваг щодо 
міри обсягу, глибини та концентрації уваги, яку необхідно генерувати задля досягнення задовільної суб'єктивної оцінки автором результатів своєї роботи. Як виявила практика, цей підхід базується на тому, що ми вибудовуємо простір безпеки шляхом позбавлення негативних переживань саме через запобігання ризикам заглиблення в травматичний досвід. Адже 3 2014 по 2019 рік застосування такого підходу в заходах декомпресії та адаптації військовослужбовців, членів їхніх родин, інших громадян та спільнот, які потребували екологічних методів зниження гостроти реактивної компоненти своєї поведінкової моделі, підтвердили його ефективність. Окрім того, випадки, коли виникала необхідність психотерапевтичного втручання, пов'язаного із розладами, які були діагностовані проективним шляхом та методом спостережень -- яскраво виокремлювались. 3 огляду на досліджувану симптоматику таким особам в індивідуальному порядку були надані рекомендації звернутись до фахівців вужчої спеціалізації. Відомо, що Україні бракує медичних фахівців, які працюють із розладами внаслідок психотравмуючих подій, і такі фахівці надзвичайно перевантажені. I тому запропонована методологія застосування арт-терапевтичного тренінгу в вищезазначених програмах виявилася ефективною щодо діагностичного комплексу диференціації випадків фахівцями іншого, ніж медична психологія, спектру психологічних компетенцій, і таким чином було означєно тенденції щодо розширення можливостей системи громадської охорони здоров'я. А запропонована арттерапевтична техніка виправдала себе як відновлювальна та така, що сприяє соціалізації шляхом відтворення комунікативних навичок i iнших соціономічних якостей.

Тут слід особливо підкреслити, що у фахівця базовою має бути спеціалізація в сфері психологія та системна спеціалізована підготовка в програмах академічної мобільності з формування кваліфікаційних навичок щодо диференціації спектру реакцій на стрес-фактори й вплив психотравмуючих подій, а також значний практичний доробок саме в сфері застосування методів декомпресії, психоемоційного розвантаження та саморегуляції.

Отже, при застосуванні цього тренінгу в програмах абілітації, декомпресії та соціально-психологічної адаптації ми відзначили загальне зниження рівня стигматизації навколо проблеми ПТСР в створеному просторі взаємодії шляхом розкриття творчої компоненти в структурі особистості та створеня “атмосфери обізнаності задля досягнення цільової діяльності" [5]. Оскільки тренінг пройшов інтенсивну апробацію в вищенаведених заходах, ми мали можливість переконатись, що застосування цього тренінгу в системі комплексних заходів програм слугувало меті підвищення загальної соціономічної компетентності учасників, які брали в ньому участь. А застосування арт-терапевтичних методик у тренінгах, метою яких була постановка навичок психоемоційної саморегуляції, значно впливає на зниження показників інтегративного психосоціального фактору ризиків, що пов'язані з розбудовою сектору громадської охорони здоров'я (Public Health as a system) [2 cт.167]. Учасники мали можливість ознайомитись та застосувати запропоновані техніки зняття внутрішньої напруги, пов'язаної не тільки із відкладеними гострими реакціями на стрес, a iз виявленим у військовослужбовців стресом рутинної життєдіяльності й емоційного 
знебарвлення та стигматизації проблематики посттравматичного спектру. Запропонована до розгляду композиція елементів методів і методик психоемоційної саморегуляції, що склала суть тренінгу як підходу щодо постановки нових або відновлення втрачених персональних дефіцитарних навичок, $є$ надбанням різних модальностей психотерапевтичної парадигми й зарекомендувала себе як надійний короткотерміновий засіб психоемоційної саморегуляції, стабілізації та психоемоційної корекції [4] шляхом міжособистісної взаємодії. Водночас, такий засіб $є$ ефективним завдяки гнучкості тренувального формату й перспективним в напрямку відновлення соціономічних якостей i має стати підтримкою для застосування психологічних практик фахівцями психологічної галузі, оскільки визначально грунтується на поведінкових аспектах особистості (а тому має доведену доказову базу), у тому числі й під час впливу стрес-факторів.

1. Доступ: http patriotdefence.org/assets/upload/general/books/vijskovapsixologiya-v-ukrayini-problemi-ta-vikliki-vprodovzh-cziklu-rozgortannyabojovixdij/vijskova_psixologiya_v_ukrayini_problemi_ta_vikliki_vprodovzh_czi klu_rozgortannya_bojovix_dij.pdf

2. Державна політика у сфері охорони здоров'я : кол. моногр. :у 2 ч. / [кол. авт. ; упоряд. проф. Я. Ф. Радиш ; передм. тазаг.ред. проф. М. М. Білинської, проф. Я. Ф. Радиша]. - К. : НАДУ,2013. - Ч. 1. - 396 с.

3. Психологічна травма та шлях до видужання: наслідки насильства - від знущань у сім’ї до політичного терору [Текст] : Д-р Джудіт Герман; переклад 3 англ. Оксана Лізак, Оксана Наконечна, Олександр Шлапак. Львів : Видавництво Старого Лева, 2015. - 416 с.

4. Ічанська О.М. Відповідальність майбутніх авіаційних спеціалістів в контексті проблеми безпеки / О.М. Ічанська // Актуальні проблеми психології : зб. наук. праць / за ред. С.Д. Максименка. - К. : НАУ, 2012. Т.Х, вип. 21. - С. 73-82.

5. Програма академічної мобільності: Training Seminar of Post Traumatic Stress Disorder (PTSD), Complex PTSD, Co-morbid Problems, and Principles of Trauma Treatment (80+ hours). On the recommendation of Dr. Daria Shewchuk, Registered Counselling and Clinical Psychologist in B.C. Canada and approved servise provider for Veterans Affairs of Canada. Maple Hope Foundation International Association for Support of Ukraine 


\title{
ASPECTS OF MENTAL HEALTH PROTECTION IN MILITARY SERVICE IN THE CONDITIONS OF MILITARY ACTION AND IN THE POSTBOY ADAPTIVE PERIOD
}

\author{
Iryna Guzenko
}

National Academy of ground Forces named after hetman Petro Sagaidachniy, Lviv, Ukraine

\begin{abstract}
For the last five years, a topical issue for sociologists, psychologists, and medics has been the study, diagnosis, and use of methods of treating traumatic and post-traumatic stress disorders in servicemen who have returned from combat. Mental health care in warfare is the skilled care of soldiers in combat, as well as in the transition from military service to civilian life based on training and rehabilitation, and complete recovery from post-traumatic stress disorder (PTSD).
\end{abstract}

Keywords. Stress, psycho-traumatic factors, post-traumatic stress disorder, flushes, intrusions Стрес, психотравмуючі чинники, посттравматичний стресовий розлад, флеш беки, інтрузії.

\section{АСПЕКТИ ОХОРОНИ ПСИХІЧНОГО ВІЙСЬКОВОСЛУЖБОВЦІВ В УМОВАХ БОЙОВИХ ДІЙ І В ПОСТБОЙОВИЙ АДАПТИВНИЙ ПЕРІОД}

Бойові дії на Сході України, що на сьогоднішній день $є$ справжньою війною, спровокували хвилю проблем психосоціальної адаптації, в якій посттравматичний стресовий розлад набув нових якісних i кількісних характеристик. Актуальним питанням сьогодення $\epsilon$ вивчення проблем збереження психічного здоров'я військовослужбовців в бойових умовах та в період адаптації до умов мирного життя.

Війна приносить не тільки фізичні, а й душевні травми. Учасники бойових дій, часто навіть не усвідомлюючи цього, несуть в собі вантаж болю довгі роки. Одні можуть подолати ці проблеми самостійно. Іншим необхідна психологічна допомога і підтримка протягом усього життя.

Військовослужбовці, виконуючи особливі функції, виявляються найбільш уразливими у фізичному й моральному аспектах і несуть основний тиск всіх наслідків збройних конфліктів. Тому, з очевидністю, випливає багатозначність психологічних перевантажень, емоційно-стресової напруженості військовослужбовців, котрі беруть участь у збройних конфліктах. Екстремальність умов бойових дій виражається в інтенсивності стрес-фактора, раптовості, небезпеці, тотальному впливі на великі групи людей, а також тривалим i важким плином постекстремальних психічних розладів. Екстремальні умови діяльності з психологічної точки зору характеризуються наявністю сильного психотравмуючого впливу подій і обставин на психіку військовослужбовця. Унаслідок багаторазово раптово діючих психотравмуючих чинників в екстремальних умовах життя, виникають групові психогенні розлади, інакше кажучи, групові психози. Страх, безвихідь, 
пригніченість та інші емоційні стани при продовженні дії психотравмуючих факторів призводять до виникнення психологічного стресу. Разом із бойовим досвідом військовослужбовці отримують фізичні й психологічні травми, а їхня психіка зазнає значних змін. Досвід ООС (АТO) засвідчує, що основною реакцією військовослужбовців на бойові події $є$ бойовий стрес, спричинений стрес-факторами бойової обстановки. 3 часом у військовослужбовця 3'являються симптоми психічних розладів, викликаних високою нервовопсихічною напругою безпосередньо в ході виконання службово-бойових завдань. Вони поділяються на поведінкові реакції (сильне тремтіння, апатія, загальмованість рухів, слізливість, дратівливість і злість, буйство), психічні реакції (нездатність концентрувати увагу, часткова або повна втрата пам'яті, швидкості мислення й ослаблення волі, чутливість до шуму), соматичні реакції (ослаблення зору й слуху, часте сечовипускання, розлади шлунку, утруднене дихання, сильна напруга м'язів, прискорене серцебиття, болі в попереку).

Очевидно, що чим більш інтенсивний бойовий стрес пережив військовослужбовець у бойовій обстановці, тим більше ймовірність виникнення в нього негативних психологічних наслідків після припинення впливу бойових стресорів. Наявність у житті події, що виходить за рамки звичайного людського досвіду, $є$ фактором, що травмує і дозволяє включити людину до групи ризику щодо виникнення ПТСР.

Посттравматичний стресовий розлад (ПТСР) - це важкий психічний стан. Якщо рани можуть зажити, а шрами, зрештою, стягнуть шкіру, - то психічний розлад може дати про себе знати і через роки після травми.

Симптомами посттравматичного стресового розладу є інтрузії (повторювані нав'язливі спогади, які виникають спонтанно, але при цьому людина перебуває в моменті "тут і зараз", та флешбеки (мимовільне і непередбачуване пожвавлення травматичного досвіду через надзвичайно яскраві спогади, що тривають від кількох секунд до кількох годин, під час яких ветеранам здається, що страшна реальність 3 минулого вторгається в їх справжнє життя.).

Потрібно говорити про потужні стресогенні фактори. А у бійця це в сто разів більше, в сто разів більш посилені спогади, які не дають йому спокою, виникають спонтанно і некеровані ним. У таких бійців відбулися збої в адаптаційному механізмі.

Згодом учасники таких екстремальних подій починають страждати на психічні розлади та відчувати труднощі у процесі адаптації до мирного життя. Участь у бойових діях впливає на свідомість людини, піддаючи іï серйозним якісним змінам. Посттравматичні стресові порушення сприяють формуванню специфічних сімейних відносин, особливих життєвих сценаріїв i можуть впливати на все подальше життя людини.

Таким чином, ефективна охорона психічного здоров'я передбачає безперервний моніторинг чинників стресу та наслідків стресу. Навіть найкращі заходи 3 охорони психічного здоров'я не можуть усунути всіх проблем, пов'язаних зі стресом, які здатні впливати на професійне функціонування чи стан здоров'я. Важливість кваліфікованого піклування про солдатів в зоні бойових дій, а також під час переходу від військової служби до цивільного життя засноване на навчанні та реабілітації, а також повному відновленні після посттравматичних стресових розладів (ПТСР). Процес одужання після фізичних та емоційних травм, отриманих під час збройних конфліктів, возз'єднання із сім'єю та реінтеграція, оперативна психіатрія, методи 
запобігання самогубствам $є$ першочерговим завданням у суспільстві з метою збереження психічного та фізичного здоров'я військовослужбовців.

СПИСОК ВИКОРИСТАНИХ ДЖЕРЕЛ

1. Алещенко В.І. Психологічна реабілітація військовослужбовців 3 постстресовими психічними розладами: Навчальний посібник / В.I. Алещенко, О.Ф. Хміляр. - Харків, ХУПС. - 2005. - 84 с.

2. Ломакін Г.І. Прояви порушень реадаптації учасників бойових дій у системі суспільних відносин / Геннадій Іванович Ломакін - Проблеми емпіричних досліджень у психології, 6-7 грудня 2012p., Київ: Матеріали VI Міжнародної науково-практичної конференції / За ред. І.В. Данилюка, І.В. Ващенко. - К.; OBC, 2012. - c. 94-100.

3. Охорона психічного здоров'я в умовах війни [Текст] : [пер. 3 англ.] : у 2 т. / [Айлін Кім, Алан Л. Петерсон, Альберт Ю. Сайто та ін.] ; Америк.-укр. мед. фундація. - Київ : Наш формат, 2017. - ISBN 978-966-2502-13-8.

4. Психологія бою: Посібник/Грицевич Т.Л., Гузенко I.М., Капінус О.С., Мацевко Т.М., Романишин А.М.; за ред.А.М. Романишина. - 352 с

(C) NDSAN (MFC - coordinator of the NDSAN), Italy, 2019 


\title{
Mental health and communication risks: socio-psychological support of the individual in the process of adaptation to peaceful life
}

\author{
Tetiana Larina \\ Institute for Social and Political Psychology, National Academy of Educational \\ Sciences of Ukraine, Kyiv, Ukraine
}

\begin{abstract}
To maintain human mental health in modern conditions of life, it is necessary to pay attention to the restoration of natural stabilization sociopsychological practices, as well as increasing the level of personal control over communicative risks. The purpose of our study is to uncover the possibilities of socio-psychological support for people who have suffered from communicative risks. We set ourselves the task of determining what helps people achieve stabilization of their mental state after experiencing communicative failure. The methodology of our research is based on theoretical methods of scientific knowledge. We analyzed the factors of violation of the socio-psychological adaptation of a person and the deterioration of his mental health in a situation of communicative failure. The model of the program of socio-psychological support should include the following main blocks: organization of trusting relationships in the family; the introduction of health-preserving forms of social activity in everyday life; prevention of pathogenic communication and correction of communicative personality attitudes. The biggest limitation of this study is the lack of empirical data on the effects of communicative risks at different stages of personality development. Among the positive aspects, it should be noted the prospect of studying the impact of communicative practices on the state of mental health. As a result, when working with people who have become victims of communicative risks, we propose to rely on the rehabilitation potential of psychoemotional self-regulation and self-help of a person, for example, an objection to collaborativeness, empathy and trust in the world.
\end{abstract}

Introduction. Prompt informatization of society, activation of information wars in the territory of Ukraine, development of computer technologies make a significant impact on the transformation of the communicative, thinking, motivational and emotional sphere of man and forms a new environment for the development and functioning of mental processes. In particular, overloading on an individual's adaptive resources, coupled with a major restructuring of the structure and dynamics of human activity and forms of human interaction in general, can cause great harm to mental health. As a consequence, attempts to stabilize one's own mental state are increasingly characterized by unmanageability and chaos, and is manifested in non-constructive communication. Therefore, in order to preserve the mental health of the individual in today's life conditions, it is necessary to revive natural stabilizing socio-psychological practices. It should also help to increase the level of conscious control of the individual over communicative risks.

Purpose. The purpose of this study is to uncover the potential of social and psychological support for victims of communicative risks to stabilize their mental state.

Design/Methodology/Approach. The methodology of our study is based on theoretical methods of investigating the factors of impairment of human adaptation, deterioration of his mental health when interacting with 
communicative risks. Our in-depth analysis of the facts studied is aimed at constructing hypotheses on theoretical models regarding the organization of social and psychological support of the victims of communicative risks.

Results. Communicative risks increase the information insecurity of a person. When a person consumes products of modern communication technologies, uses media forms of creation and transmission of information in interpersonal communication, there is a risk of losing critical attitude to the reliability of information. Today, anyone who is an active user of social networks can easily fall prey to fake information, fake news and fake pages that spread lies or manipulate truth. Cultivating the instinct of consuming communication attributes, updating the chain of unconscious psychological response to the pursuit of prosperity (Baudrillard, 2006) makes one virtually defenseless against destructive media information and manipulative technologies of influence

The imbalance of the information space, the combination of incompatible in content and form of communication characteristics increases the risk of destabilization of mental states of the individual. The ambiguity of communicative strategies, the inability to clearly distinguish between monologic and dialogic rules of communication provokes in the person spontaneous mental manifestations and decapitated psychological states. The palette of these manifestations often lies in the communicative plane from uncontrolled verbal aggression to bouts of deep sensuality and genuine compassion.

When designing a model of social and psychological support for those affected by communicative risks, we have taken into account the positive effects of the use of technology to restore psychological health after a war-related trauma (Tytarenko, 2018), technologies to restore individual vitality (Larina, 2019) and mobile applications for preventing the devastating effects of psychotraumatisation during the hybrid war (Dvornyk, 2018). Thus, to ensure that communicative risks do not reduce the mental and psychological resources of the individual to a critical adaptive level, the focus of socio-psychological support programs should be: control over maintaining trust in the family; initiation of health-saving forms of social activity in everyday life; prevention of pathogenic communication and correction of communication attitudes of the individual. All these psychological support activities help the individual to maintain a stable mental state and maintain their own psychological health.

Limitations and strengths of the study. The biggest limitation of this study is the lack of empirical data on the effects of communicative risks at different stages of personality development. In spite of this, we see a rather poor prospect of studying the impact of communicative practices on one's mental health.

Practical/Social value. The social and practical value of the steps to organize the social and psychological support of the victims of communicative risks is to stabilize the psycho-emotional states of the individual and to strengthen their mental health.

Originality/Conclusions. We suggested that when organizing social and psychological support, we should rely on the rehabilitation potential of selfhealing and restoration of the natural tendency to cooperate, empathize and renew basic trust in the world. An indicator of the effectiveness of psycho-interventions is the unlocking of socio-psychological resources of the transition from reactive coping strategies for minimization communicative risks to proactive coping strategies. 


\section{References.}

Baudrillard, Jean (1970). La société de consommation: ses mythes et ses structures [Obshhestvo potrebleniya. Ego mify i struktury (E. A. Samarskaya, Trans) (2006). Moscow: Centr gumanitarnykh tekhnologyj [in Russian] URL: https://gtmarket.ru/laboratory/basis/3464.

Dvornyk, M.S. (2018). Mobilnyy zastosunok u systemi sotsialno-psykholohichnoyi reabilitatsiyi travmovanoyi osobystosti [Mobile application in the system of socio-psychological rehabilitation of traumatized personality]. Naukovi studiyi iz sotsial'noyi ta politychnoyi psykholohiyi 41(44), 192-201. [in Ukrainian].

Larina, T.O., \& Tytarenko, T.M., Hundertailo,Yu.D., Dvornyk, M.S., Klymchuk, V. O., Lazorenko, B.P., et al. (2019). Tekhnologiyi vidnovlennya socialnopsykhologichnykh resursiv zhyttyezdatnosti osobystosti, shho perezhyvaye naslidky travmatychnykh podij [Technologies of restoration of social and psychological resources of vitality of the person experiencing the consequences of traumatic events]. Sotsialno-psykhologichni tekhnologiyi vidnovlennya osobystosti pislya travmatychnykh podi: praktychnyj posibnyk - Socio-psychological technologies of personal recovery after traumatic events: practical guide, (pp. 95-112). Kropyvnytskyi: Imeks-LTD sotsial'no-psykholohichna reabilitatsiya osobystosti: etapy, tekhnolohiyi, tekhniky. [in Ukrainian].

Tytarenko, T.M. (2018). Sotsialno-psykholohichna reabilitatsiya osobystosti: etapy, tekhnolohiyi, tekhniky [Socio-psychological rehabilitation of personality: stages, technologies, techniques.in Ukrainian]. Naukovi studiyi iz sotsial'noyi ta politychnoyi psykholohiyi 41(44), 157-167. [in Ukrainian].

Keywords: mental health, communication risks, socio-psychological support, coping strategies 


\title{
Mental Health Levels among University Students - Bordj Bou Arreridj University as a Model
}

\author{
Dr. Tezkratt Abdenacer
}

University Mohamed El Bachir El Ibrahimi- Bordj Bou Arreridj - Algeria

\begin{abstract}
.
The present study aimed to identify the reality of mental health among students at Mohamed El Bachir El Ibrahimi- University of Bordj Bou Arerridj- as a model- and study the differences between students considering the variables of sex, major and level by following the descriptive method, and the study adopted the mental health scale SCL 90-R (abu Hayn, 1992): Physical symptoms, Obsessive-compulsive disorder, Interactive allergy, Depression, Anxiety, Enmity, Phobia, Paranoia, Psychosis. Which was applied to a sample of 400 students from all levels of literary and scientific disciplines of the university faculties.
\end{abstract}

The statistical Package in social sciences (SPSS)- version 22- was adopted to analyses the study data. The outcome is as follows:

- There are no statistically significant differences between the mental health averages of university students due to the sex variable (male/ females).

- There are no statistically significant differences between the mental health averages of university students due to the major variable (literary/ scientific).

- There are no statistically significant differences between the mental health averages of university students due to the education level variable (first year, second and third years bachelor, first year and second year master).

We conclude that there are no differences in mental health among students of the University of Mohamed El Bachir El Ibrahimi.

Keywords: Mental health, Students, University, University Training, Depression, Obsessivecompulsive disorder, Phobia, Paranoia, Psychosis

(C) NDSAN (MFC - coordinator of the NDSAN), Italy, 2019 
What is "good", what is "bad"? Experience of Institutional (medical) system of MHC

\title{
The staff and patients of MHC medical Institutions as a small social groups. Interpersonal and intergroup relations
}

\author{
Viktor Vus \\ Institute for Social and Political Psychology National Academy of Educational Science of \\ Ukraine, Kyiv, Ukraine \\ National University "Lviv Polytechnic", Lviv, Ukraine
}

Introduction. The modern world community is actively seeking to improve the Mental Health Care system

Purpose. The aim of the study is to analyze the motivation of people with mental health disorders to receive medical and social assistance in the context of the Institutional (medical) system of Mental Health Care

Methodology. 109 patients were examined: 69 men and 40 women suffering from paranoid schizophrenia. The age of men - from 20 to 61 years, the age of women from 18 to 64 years. Patients met the criteria for schizophrenia according to the ICD - 10 and the PANSS scale. In a survey of patients, questionnaires of selfstigmatization, social functioning and quality of life, the "PANSS", "SANS", "BPRS", "GAF" and drug compliance questionnaires were used

Results. In this research, much attention was paid to the study of the motivational determinants of receiving medical and social assistance by persons with schizophrenia.

Most of the respondents (70.9\%) are independently consulting a psychoneurological dispensary for medical and social assistance. $7.8 \%$ - in response for a call.

But not all of them seek treatment exclusively (only 45.6\%). That is, we can speak that the nature of requests for medical and social assistance in the clinic is also associated with the satisfaction of certain social and psychological needs. As, as practice shows, the conditions of the clinic create for the mentally ill persons a separate social microenvironment, where part of their life passes, get the skills of interpersonal interaction, develop and develop appropriate social skills, behavioral patterns, outlook

The sampling distribution of the overall life assessment showed the following results:

- not satisfied with life - $10.7 \%$;

- Rather dissatisfied than satisfied - $18.4 \%$;

- Rather satisfied than dissatisfied - 34\%;

- Fully satisfied - 36.9\%.

The proportion of those with very poor mental health is $1.9 \%$; bad $-20.4 \%$. Mental health was found to be satisfactory in $68 \%$ of those surveyed

The vast majority of respondents $(67 \%)$ were satisfied with their mental health status. Dissatisfied - 33,2\%.

At the time of the survey, $19.4 \%$ of the subjects were in poor physical condition. 
Physical health was rated as "good" by $80.6 \%$ of those surveyed.

However, $23.3 \%$ of those surveyed expressed dissatisfaction with their physical well-being. The share of satisfied people was $76.7 \%$ of the total sample

However, $26.2 \%$ of those surveyed expressed dissatisfaction with their physical performance. Satisfied with their physical capacity $73,8 \%$.

According to the self-assessment of their intellectual productivity, the respondents were divided as follows:

- dissatisfied - $12.6 \%$;

- Rather dissatisfied than satisfied - 8.7\%;

- more satisfied than dissatisfied - 35\%;

- fully satisfied $-43.7 \%$.

Consequently, the identification of work activity of mentally ill persons has a number of limitations of clinical, social and personality character. Often, their work activity is limited by social and legal norms (disability status). However, 57.2\% of the respondents were satisfied with their social benefits and preferences. And a considerable part of the respondents (19.4\%), having retained working capacity, do not carry out work activities.

According to the results of the study of the specific activity of the mentally ill persons daily, it was found that $5.8 \%$ of the respondents walk only a few times a month. Almost $77.7 \%$ go beyond their premises almost daily; once or twice a week $-16.5 \%$.

They make purchases in stores daily $39.8 \%$ of the surveyed. During the week they visit the shops several times $34 \%$; once - $17,5 \%$ of the studied. $7.8 \%$ of the respondents visit the shops only 1 - 2 times a month.

Public transport services are used daily by $43.7 \%$; 1 - 2 times a week - 33\%; several times a month $-20,4 \% .2 .9 \%$ of those surveyed never use public transport.

The vast majority of respondents read literary works daily or occasionally (37.9\% and $52.4 \%$, respectively). However, $9.7 \%$ practically never read.

At the same time, $49.5 \%$ of those surveyed never or rarely watch television. The other half are watching television daily.

As for leisure activities, $3.9 \%$ of those surveyed visit theaters, cinemas, museums and other recreational sites daily. These places visit $8.7 \%$ every week. Monthly and quarterly $-19.4 \%$ and $6.8 \%$ respectively; semi-annually and once a year $-12.6 \%$ and $18.4 \%$, respectively.

However, about a third of respondents (30.1\%) never visit such cultural sites.

$12.6 \%$ of respondents practically never interact with friends and acquaintances. Significant limitations of interpersonal interaction were found in $7.7 \%$ of the respondents (yes, they maintain social contacts only quarterly - 3.9\%; semiannually - $1.9 \%$; once a year $-1.9 \%$ ).

$38.8 \%$ have interpersonal contacts daily; weekly $-26.2 \%$; once a month $-14.6 \%$.

$30.1 \%$ of respondents cannot organize their own leisure activities. At least once a month, they spend $10.7 \%$ on hobby time.

$28.2 \%$ do their hobbies daily; several times a week - $16.5 \%$; several times a month $-14,6 \%$. 
Only $26.2 \%$ of the respondents are able to serve themselves in everyday life. Mostly served by relatives $-14.6 \%$.

$23.3 \%$ of the respondents expressed their dissatisfaction with the level of their daily activity. The vast majority of those surveyed (76.7\%) were satisfied.

Consequently, a considerable part of the respondents $(20.3 \%)$ found the limited social contacts, the complexity of interpersonal interaction. About a third of those surveyed $(30.1 \%)$ never visit cultural sites and are unable to organize their own leisure activities. Only $26.2 \%$ of the respondents are fully able to service themselves in everyday life.

However, the vast majority of those surveyed (76.7\%) were satisfied with their daily activity level.

According to the degree of life satisfaction, the research was distributed as follows:

- completely dissatisfied - $13.6 \%$;

- rather dissatisfied than satisfied - $13.6 \%$;

- more satisfied than dissatisfied - 34\%;

- Fully satisfied - $38.8 \%$.

The results of the study of subjective well-being revealed:

- absolutely unhappy - 5.8\%;

- mostly unhappy life - $16.5 \%$;

- overall prosperous life - 53.4\%;

- quite happy - $24.3 \%$.

Conclusions. According to the results of the study it is possible to state:

- In a large part of the subjects, the limited social contacts, the complexity of interpersonal interaction, the difficulty of detecting daily and social activity were revealed;

- there is a tendency to legitimize the problems of their social activity in the status of disability (thus they can shift responsibility for their lives to the state $\backslash$ society)

- there is a tendency towards a specific transformation of the perception of objective social reality, a peculiarity of psychological attitudes of social perception

- the existence of an experience of antagonism between the world of "healthy" and the world of "sick"; the desire to find something more comfortable and comfortable for them in society

- the nature of patients' requests for medical and social assistance in the context of the Institutional (medical) system of mental health care is also associated with the satisfaction of certain socio-psychological needs;

- the conditions of the clinic create for the mentally ill persons a separate social microenvironment where part of their life passes, get the skills of interpersonal interaction, develop and develop appropriate social skills, behavioral patterns, outlook

- psychiatric clinic staff, other patients become the most favorable living environment for people with mental health disorders

Therefore, the advantage of the Institutional (medical) system in the perception of 
people with mental health disorders is the ability to create a closed, safe, and developmental environment for them

Keywords: mental health; mental health professionals, mental health staff, Institutional system of Mental Health, quality of life, medical support, social support

(C) NDSAN (MFC - coordinator of the NDSAN), Italy, 2019 


\title{
DEVELOPMENT OF CONFIDENCE OF MUSICIANS-BEGINNERS IN PREPARATION FOR PERFORMANCE ACTIVITIES
}

\section{РОЗВИТОК ВПЕВНЕНОСТІ МУЗИКАНТІВ-ПОЧАТКІВЦІВ ПРИ ПІДГОТОВЦІ ДО ВИКОНАВСЬКОЇ ДІЯЛЬНОСТІ}

\author{
Vira Fedorenko \\ Boguslav humanitarian college named after Nechuy-Levytsky, Boguslav, Ukraine \\ КВНЗ КОР «Богуславський гуманітарний коледж \\ імені I.С.Нечуя-Левицького», Богуслав, Україна
}

\begin{abstract}
.
The article discusses different approaches to overcoming the excitement before the performance and offers ways of psychological adjustment for the optimal state of health on the stage of beginner musicians.

Keywords: positive aspect of experience, optimal setting, personal meaning, confidence-building algorithm.

У статті розглядаються різні підходи до подолання хвилювання перед виступом та пропонуються способи психологічного налаштування для оптимального самопочуття на сцені музикантів-початківців.

Ключові слова: позитивний аспект переживань, оптимальне налаштування, особистий сенс, алгоритм набуття впевненості.
\end{abstract}

\section{Постановка проблеми.}

Концертний виступ для музиканта-початківця майже завжди є важливою та урочистою подією. Ї̈̈ важливість полягає, перш за все, в тому, що це підсумок його навчання, результат різних аспектів його підготовки. Цінність цієї події в тому, що такий виступ може стати як святом, яке надихає i стимулює музиканта працювати далі, так і травмуючим досвідом, який надовго зупинить його у професійному розвитку.

Саме тому питання психологічної підготовки майбутніх музикантів до виступу $€$ вкрай важливим. Мова йде не лише про художню цінність виконавства, контакт із аудиторією, виразність, а, в першу чергу, про особистість самого виконавця, його бажання або небажання виступати, і в підсумку - про те, чи буде отримувати задоволення сам виконавець. Адже для того, щоб принести радість слухачам, цю радість має отримувати і сам виконавець.

Аналіз попередніх досліджень і публікацій.

Упродовж багатьох років питаннями виконавської діяльності займались такі музикознавці, педагоги та психологи як М. Давидов, Г. Коган, Я. Мільштейн, Г. Нейгауз. Психологічні аспекти музично-виконавської діяльності аналізуються у дослідженнях О.Костюка, Б.Теплова, Ю.Цагареллі, Т.Цигульської.

Проблеми творчої активності особистості висвітлювались у працях Ю.Бабанського, В.Кан-Калика, С.Сисоєвої. Психологічний аспект «сценічного хвилювання» розробляли Л.Бочкарьов, А. Готсдинер, В. 
Петрушин, Г. Ципін.

Метою статті $\epsilon$ дослідження різних підходів до подолання хвилювання перед виступом та розробка способів психологічного налаштування для оптимального самопочуття на сцені.

Виклад основного матеріалу.

Слід зауважити, що багато праць, присвячених цій проблемі, характеризують переживання перед виступом здебільшого в негативному аспекті - страх сцени, тривожність, подолання хвилювання тощо.

Ми вважаємо, що більш доцільно говорити про ці переживання в позитивному ракурсі, коли увага акцентується не стільки на тому, чого слід позбутися, скільки на тому, що варто набути для успіху на сцені: досягнути впевненості у виступі, отримати задоволення, пережити весь спектр артистичних емоцій, розкритись, поділитись своїми переживаннями 3 аудиторією, донести те цінне, що є в особистості виконавця та в музичному творі до глядача.

На думку Ю. Цагареллі, концертний виступ $є$ підсумком і кульмінаційним моментом всієї роботи над музичним твором. Його мета - доведення до слухача змісту музичного твору в умовах стресової ситуації. Серед операцій, що сприяють виконанню цієї мети, можна назвати: особисте налаштування перед концертом, регуляцію виконання 3 урахуванням акустичних особливостей залу, реакції слухачів на виконання, власного психологічного стану в екстремальних умовах, видовищне оформлення виступу.

У контексті аналізу специфічних особливостей концертного виступу відзначимо, що крім необхідності психологічної готовності (налаштування), а також підготовленості виконавця (що відзначається більшістю авторів), необхідним є високий рівень стресостійкості. Адже досить часто концерти проходять у залах з неідеальними слухачами, під час виступу трапляються різноманітні перешкоди, і тому особливі вимоги пред'являються як до саморегуляції виконавця, так і до стабільності виконання [6].

3 точки зору Л. Лабінцевої, важливу роль у стабілізації концертного стану відіграє регулярність концертних виступів. У такому випадку концертне хвилювання, що виникає в кожному виступі, не встигає зникнути, а наче залишається у пам'яті в достатньо актуальному вигляді. Свідомість утримує деякі його структури, оскільки зберігається інформація про наступний концерт [3].

Згідно досліджень М.В. Іваненко, навіть талановитий, якісно підготовлений студент, котрий напередодні академічного концерту виконав програмний репертуар ідеально, під час публічного виступу часто починає губити інтонацію, всі напрацьовані технічні виконавські аспекти. Ці фактори повинні стати сигналом для викладача, адже вчасно не поборовши в студентові зародки «страху сцени», в наслідку можна випустити професійно непридатного артиста. 3 часом ця вада може або поглибитись до панічного страху сцени, що стане наслідком появи невпевненості у власних здібностях, i, як наслідок, завершення виконавської діяльності, або призведе до постійного «сценічного хвилювання», що межує зі страхом і несе шкоду виконавському процесу, забираючи у виконавця всі наявні тембральні барви, палітру власних здібностей як музичних, так і акторських.

Велика кількість студентів може мати феноменальні здібності, але так і не виступити на великій сцені, через те, що вони не можуть подолати страх 
перед сценою. I це може бути найбільшою проблемою музикантапочатківця, через яку він може зійти зі сцени, бо не може відкритись слухачеві повністю, а отже, не досягає повноцінного спілкування із слухачами. Тоді як його мета - донести переживання тривоги, щастя, радості, смутку, кохання тим, хто знаходиться в глядацькій залі. Бажаного результату можна досягти, лише досягнувши вільного відчуття на сцені. Відтак, робота в класі з початківцем повинна базуватись не лише на прагненні оволодіння технічними навичками, а й на розвитку артистизму та впевненості [2].

Як зазначає Є.В.Богдан, у передконцертний період важливим є збереження нервово-психічної енергії для майбутнього виступу. Тому на перший план виходять такі завдання: вирішення внутрішнього конфлікту, постановка адекватних завдань, організація систематичних занять, тобто спрямування уваги та мислення студентів на вирішення художніх та технічних завдань, $\mathrm{i}$ відволікання від думок про концерт взагалі, від можливих невдач або приголомшливого успіху.

Освітньо-виховна робота 3 підготовки студентів до концертів включає такі компоненти:

- розуміння концертного життя як норми;

- глибокий "молекулярний" розбір музичного матеріалу та усвідомлення його образного змісту;

- посилення мотивації до художньої діяльності, на противагу егоїстичним прагненням;

- формування здатності студентів до вольових зусиль та вольової регуляції поведінки;

- тренування здатності до концентрації уваги в умовах виступу;

- контроль над організаційними моментами виступу [1].

На вважливі аспекти, які істотно впливають на самопочуття музикантапочатківця, вказує Л. Радковська. На ії думку, викладачу потрібно створити такі умови навчання гри на інструменті, щоб студент отримав задоволення від спілкування не лише із музикою, а й із викладачем, адже позитивне ставлення налаштовує вихованця на спілкування, а негативне породжує внутрішній протест, порушує емоційну рівновагу.

Також вагомий вплив мають способи спілкування студентів з батьками, зокрема розуміння тих вимог, які вони ставлять до своєї дитини. Батьківський контроль може вилитись як у позитивний, так і негативний результат. Наприклад, недостатня увага, байдужість до успіхів чи невдач сина чи дочки, на думку психологів, може стати причиною появи переживань і тривоги не лише на занятті, а й під час концертних виступів, а страх бути покараним за погану оцінку або зауваження викладача призводять до заниження самооцінки.

Не останню роль, на думку дослідниці, грає недостатньо грамотно підібрана програма для виконавця. Зокрема, викладачі часто обирають для концертів чи виступів складні твори, щоб продемонструвати рівень досягнень студентів свого класу, проте на практиці все обертається навпаки. Щоб цього не сталося, професіонали рекомендують підбирати для концертних виступів твори, враховуючи реальні можливості кожного виконавця, аби показати таким чином його сильні сторони, індивідуальність, характер, темперамент тощо) [4]. 
На важливому аспекті підготовки музиканта до виступу акцентує Г.Ципін. В своїх роботах дослідник вказує, що на самопочуття виконавця суттєво впливають такі фактори, як жорстка установка на успіх, гіпервідповідальність та надзвичайна самокритичність, при високих затратах нервово-психічних зусиль. Ситуація виступу набуває в очах музиканта статусу понадзначимості, та викликає сильне занепокоєння і нервове збудження [5].

Проаналізувавши підходи різних авторів, ми б хотіли зробити акцент на психологічному аспекті досягнення виконавцем того оптимального стану, який дозволить йому зробити свій виступ незабутнім для оточуючих та радісним для себе самого.

Отже, алгоритм набуття впевненості перед виступом для виконавцяпочатківця:

1. Прояснити для себе сенс виходу на сцену (мені подобається, подарувати радість, це моя робота, необхідний елемент кар'єри артиста, не можу не виступати, люблю увагу публіки, не хочу підвести своїх педагогів тощо).

2. Обговорити напрацьовані сенси 3 такими ж початківцямивиконавцями; знайти подібне і відмінне, побачити, як особистий сенс відображається в очах інших.

3. Здійснити тестовий виступ в колі одногрупників, проаналізувати свої сильні і слабкі сторони, попросити інших дати конструктивний зворотний зв'язок.

4. Відкоригувати виступ згідно отриманих настанов.

5. Напрацювати потрібну установку, тобто те переконання, яке створює необхідний настрій та відповідне позитивне налаштування.

3 досвіду можемо сказати, що, зазвичай, найбільш розповсюдженими є дві установки: «мій виступ будуть засуджувати, наді мною будуть сміятись, глядачі - експерти і висококваліфіковані фахівці, а я всього лише початківець» і «мій виступ для мене «все», від нього залежить моя оцінка, кар'єра, фінансовий стан, успіх тощо».

Зрозуміло, що подібні настанови не сприяють ефективному виступу. I робота стосовно правильного налаштування має спрямовуватись на зміну подібних очікувань.

Скажімо, можна запропонувати наступні настанови:

1. Визнати, що я молодець, що вже просто вийшов на сцену.

2. Нагадати собі, що я вчусь і розвиваюсь, і можливі помилки - лише кроки до мого успіху.

3. Якщо я десь помилився, не акцентувати на цьому увагу, не картати себе за це, а спокійно продовжувати виступ.

4. Повірити в те, що люди в залі зовсім не прагнуть мого провалу, вони налаштовані сприятливо по відношенню до мене, позитивно i доброзичливо.

5. Вкласти в підготовку максимум зусиль, щоб, орієнтуючись на власні відчуття, можна було сказати, що для цього разу я зробив, все, що міг.

6. Сконцентруватись на моменті, забути про всіх і просто отримувати задоволення від виконання твору.

7. Усвідомити, що мій виступ - це гра, як і переважна більшість 
мистецьких подій, і моїм завданням є просто зробити цю гру цікавою і захоплюючою.

\section{Висновки.}

Таким чином, для розвитку впевненості музикантів-початківців більш доцільно говорити про їх переживання в позитивному ракурсі, акцентуючи увагу на тому, що варто набути для успіху на сцені: досягнути впевненості у виступі, отримати задоволення, розкритись, донести те цінне, що $є$ в особистості виконавця та у музичному творі до глядача. Для того, щоб принести радість слухачам, радість має отримувати і сам виконавець.

Психологічний аспект розвитку впевненості музикантів-початківців здебільшого полягає у проясненні для особистості сенсу виходу на сцену та обговоренні цього питання з початківцями-виконавцями. А також важливим $€$ напрацювання потрібної установки, тобто того переконання, яке створює оптимальний позитивний настрій для виступу.

\section{Література.}

Богдан Є. В. Особливості підготовки учнів музичних шкіл до концертних виступів / С. В. Богдан // Збірник наукових праць [Херсонського державного університету]. - 2013. - Вип. 64. - С. 142-149. - (Серія «Педагогічні науки»).

Іваненко М.В. Подолання страху сцени у вокаліста-початківця: інтерпретаційний контекст. / М.В.Іваненко// Вінок митців і мисткинь. - 2019. - Вип. 2 (185). - С. 84-86.

Лабінцева Л. П. Концертний виступ як особливий вид музично-виконавської діяльності. Вісник ХДАДМ. 2010. № 1. С. 215-216.

Радковська Л. Роль викладача-інструменталіста у подоланні сценічного хвилювання учнів-піаністів дитячої музичної школи/Л.Радковська, О.Ссіпова // Нова педагогічна думка. - 2018.- №1.- С.166-168.

Цыпин Г. М. Обучение игре на фортепиано / Г. М. Цыпин. // - М. : Просвещение, 1984. - 175 с. - С.112.

Цагарелли Ю. А. Психология музыкально-исполнительской деятельности: учеб. пособ. Санкт-Петербург: Композитор, 2008. 212 с. - С.84

Ключові слова: позитивний аспект переживань, оптимальне налаштування, особистий сенс, алгоритм набуття впевненості 


\title{
Features of the Idea of University Students About Mental Health
}

\author{
Myroslava Kulesha-Liubinets
}

Elena Ruban

Vasyl Stefanyk Precarpathian National University, Ivano-Frankivsk, Ukraine

Relevance of research. Mental health, according to WHO, is a state of well-being in which a person is able to reach his or her own potential and overcome ordinary life stresses. Today, mental health disorders are in the top five of people's illnesses.

The following scientists have addressed the issues of mental health preservation: D. Bowen, L. Burlachuk, O. Vasilyeva, I. Galetska, S. Gluzman, V. Gorbunov, I. Dubrovina, V. Klimchuk, I. Koltunov, I. Kotsan, M. KuleshaLiubinets, O. Malina, M. Mushkevich, L. Peretyatko, O. Haustova, O. Chaban and others.

At the present stage of development of Ukraine, special attention should be paid to the level of mental health awareness among students of higher education institutions. After all, excessive nervous and mental stress, inflated demands on oneself, insecurity in one's own future are the factors that worsen the mental health of the young people.

The aim of the study. Conduct an empirical study of university students' perceptions of mental health.

Research methodology and organization. The study sample consisted of 60 students of Vasyl Stefanyk Precarpathian National University, including: 20 students of the 2nd year of specialty "Secondary education (history)", 20 persons of the 1st year and 20 students of 4th year of the specialty "Psychology". Among the respondents - 9 men and 51 women aged 19 years. All respondents were voluntarily surveyed.

To achieve the goal of the study we used the author's questionnaire.

Research results. The survey showed ambiguous understanding of the concept of "mental health" and its importance in life.

Future history teachers have described mental health as: "equilibrium," "adequate behavior," "self-acceptance," and more. At the same time, $40 \%$ of those polled classify mental health as "no mental disorder". Students of the first course of the specialty "Psychology" characterized mental health as: "level of psychological well-being", "satisfactory emotional well-being", "spiritual uplift" and others. Mental health was defined as "no mental disorder" by only $27 \%$ of students. Students of the 4th year of the specialty "Psychology" described "mental health" as: "psychological, social well-being", "harmony with oneself", "opportunity to realize their abilities", "acceptance of self" and others. However, no one defines mental health as the absence of mental disorders, which indicates a deeper understanding of it than the freshmen of the university.

The main ways of maintaining mental health in the opinion of young people are: meditation, sports, yoga, self-development. However, only half of the students surveyed $(54 \%)$ regularly play sports.

The self-esteem of students of the level of formation of responsible attitude to health makes $6,8-7,3$ points (lower values were shown by freshmen); 
the level of relations with others - 7.0-7.4 points (higher rates of students of the 4th year, which testifies to the developed in them communicative qualities, ability to overcome conflict situations); the level of satisfaction with personal development - 7,0-7,5 points (lower level was noted by students of the 4th year, which, in our opinion, can indicate an increase in the level of harassment).

Psychological stress was assessed by students at 3.7-5.0 points (low level of students in the specialty "Secondary education (history)"). Observations show that these students are more cohesive and confident about their profession. This thesis is confirmed by the determination of the level of happiness of students: future teachers of history - it is 7.8 unlike the students of specialty "Psychology" 4 year, who noted their own happiness at 7.2.

Conclusions. Thus, university students are not sufficiently informed about the content of mental health. Future fourth-year psychologists who have completed courses in Clinical Psychology, Pathopsychology, etc., as well as practice in hospitals, are more aware of the importance of maintaining mental health as opposed to freshmen and students in other specialties. Therefore, it is important for the university to carry out educational work to promote mental health

C NDSAN (MFC - coordinator of the NDSAN), Italy, 2019 


\title{
Mental health and art therapy: socio-psychological support of IDPs in the process of adaptation to peaceful life
}

\author{
Yuliia Hundertailo \\ Institute for Social and Political Psychology, National Academy of Educational Sciences of \\ Ukraine, Kyiv, Ukraine
}

\begin{abstract}
The mental health of IDPs in modern Ukraine needs to be maintained both at the macro and micro levels due to the high level of daily stress. The purpose of this study is to unleash the potential of art-therapeutic methods to support IDPs to stabilize their mental state. The methodology of our research is based on theoretical methods of scientific knowledge. The potential of art therapy methods and group forms of work in the process of socially psychological support for IDPs is analyzed. The focus should be on resources available to the community, such as local museums, which can become the material basis for the restoration of social activity of people with disabilities and the spread of stress management practices in everyday life. The biggest limitation of this study is the lack of empirical data on the effects of using art therapy in Ukrainian museums.

Among the positive aspects, it should be noted the prospect of improving the mental health of IDPs using art therapy in a museum. As a result, when working with IDPs, we suggest focusing on restoring a sense of security and a sense of belonging to the local population.

Introduction. The mental health of IDPs in modern Ukraine needs to be maintained both at the macro and micro levels due to the high level of daily stress. For this group, the population is characterized by the narrowness of social ties and the lack of practices for managing stress in their lives. Specialized art therapy programs can handle these tasks.

Purpose. The purpose of this study is to unleash the potential of art-therapeutic methods to support IDPs to stabilize their mental state.

Design/Methodology/Approach. The methodology of our study is based on theoretical methods for studying factors of improving a person's adaptation, improving his mental health when using art therapeutic methods. Our in-depth analysis aims to build hypotheses about theoretical models for organizing social and psychological support for IDPs
\end{abstract}

\section{Results.}

The mental health of IDPs needs the focused care of society, as people who leave their permanent place of residence during the war experience numerous stresses and crises, as well as undergo psychological trauma due to the loss of material and human resources and a lack of security. Art-therapeutic methods allow you to express and integrate your own non-verbal and verbal experience; to form an internal sense of security; acquire new social connections. Group forms of work in museums with IDPs also contribute to a sense of belonging to local communities and better adaptation to new places of residence.

When developing a model of social and psychological support for IDPs, we took into account the development of technologies for restoring psychological health after a war-related trauma (Titarenko, 2018), and art-therapeutic methods for 
recovering from psychological trauma. (Hundertaylo $\mathrm{Yu}, 2019$ ). Thus, to ensure the mental health of IDPs, it is necessary at the micro level - in the host communities - to ensure the implementation of specialized programs of sociopsychological support using art therapeutic methods. The focus should be on resources available to the community, such as local museums, which can become the material basis for the restoration of social activity of people with disabilities and the spread of stress management practices in everyday life. All these actions are aimed at maintaining a stable mental state and psychological health of people who have left their usual places of residence.

Limitations and strengths of the study. The biggest limitation of this study is the lack of empirical data on the effects of using art therapy in Ukrainian museums. Despite this, we see a rather good prospect of studying the impact of specialized programs using art methods on mental health.

Practical/Social value. The social and practical value of steps to organize specialized programs for the social and psychological support of IDPs is to strengthen their mental health.

Originality/Conclusions. When organizing specialized programs of social and psychological support for IDPs, we suggested using the resources of the local community, namely museums. An indicator of the effectiveness of psychological work is the restoration of a sense of security and a sense of belonging to the local population.

\section{References.}

Hundertailo,Yu, Larina, T.O., \& Tytarenko, T.M.,.D., Dvornyk, M.S., Klymchuk, V. O., Lazorenko, B.P., et al. (2019). Sotsial'no-psykholohichni tekhnolohiyi Vidnovlennya zhittyevoyi neperervnosti VPO [Sociopsychological technologies for the restoration of life continuity of IDPs]. Sotsialno-psykhologichni tekhnologiyi vidnovlennya osobystosti pislya travmatychnykh podi: praktychnyj posibnyk - [Socio-psychological technologies of personal recovery after traumatic events: practical guide], (pp. 131-136). Kropyvnytskyi: Imeks-LTD sotsial'no-psykholohichna reabilitatsiya osobystosti: etapy, tekhnolohiyi, tekhniky. [in Ukrainian]

Tytarenko, T.M. (2018). Sotsialno-psykholohichna reabilitatsiya osobystosti: etapy, tekhnolohiyi, tekhniky [Socio-psychological rehabilitation of personality: stages, technologies, techniques.in Ukrainian]. Naukovi studiyi iz sotsial'noyi ta politychnoyi psykholohiyi 41(44), 157-167. [in Ukrainian].

Keywords: mental health, art therapy, socio-psychological support, adaptation 
The Clinical Practice's Case. Syndrome of Megacytolysis at the Patient with the Ischemic Stroke

\author{
Iryna Gayova ${ }^{1}$, Iryna Romash ${ }^{1}$, Ivan Romash ${ }^{2}$, Neogi Reevu ${ }^{3}$ \\ ${ }^{1}$ Department of Propaedeutics of Internal Medicine, Ivano-Frankivsk National \\ Medical University (IFNMU), Ivano-Frankivsk, Ukraine \\ ${ }^{2}$ Department of Psychiatry, Narcology and Medical Psychology, Ivano-Frankivsk \\ National Medical University (IFNMU), Ivano-Frankivsk, Ukraine \\ ${ }^{3} \mathrm{GD}$ Hospital and Diabetes Institute, Kolkata, India
}

\begin{abstract}
Resume. The Clinical Practice's Case. A patient V., the woman of 73 years old, was diagnosed an ischemic stroke. At her tests were detected extremely high AsAT, AlAT and polycystic liver and kidneys. Data of ECG, bilirubins and creatinin were normal. The patient had been taken Paracetamol for last year to reduce artralgia. Paracetamol was excluded and complex treatment administered. The patient discharged from hospital with improvement and the normal data of AsAT, AlAT.
\end{abstract}

Keywords. Ischemic Stroke, Megasyndrome of Cytolysis, Polycystic liver and kidneys, Paracetamol, Heptral.

The Clinical Practice's Case. A patient V., the woman of 73 years old, complained of a severe weakness and dizziness. She suffered from arterial hypertension $(\mathrm{AH})$. The patient had been taken Paracetamol for last year to reduce artralgia. Examination: the patient's condition was moderate. Her position was an active. She coud walk herself. She answered the questions properly. Her skin and visible mucous membranes were pale and clean. Vesicular auscultation was heard over her lungs. The cardiac tones were rhythmical, the heart rate was 77 per $1 \mathrm{~min}$, pulse - 77 per $1 \mathrm{~min}$, $\mathrm{BP}=165 / 85 \mathrm{~mm} \mathrm{Hg}$. Her tongue was moist and clean. Her abdomen was soft and painless. Her liver's sizes after Kurlov: $I=14 \mathrm{~cm}, I I=10 \mathrm{~cm}, I I I=9 \mathrm{~cm}$. Her urination and defecation were normal, the ordinary colors of urine and feces. Peripheral edema was absent. Pasternatskyi's symptom was negative on both sides.

The clinical diagnosis: AH, stage III, hypertensive crises complicated with the ischemic stroke, degree 3 , extremely high risk of complications. Ischemic heart disease. Cardiosclerosis diffuse. HF-II-B, FC-III.

The laboratory and instrumental investigations' results. Blood test: platelets - 176,0 g/l, bands $-23 \%$, ESR- $23 \mathrm{~mm} / \mathrm{hr}$. Biochemical blood test. 
Common bilirubin - 14,9 mcmol/1, AlAT- 340,6 Un/1, AsAT- 805,0 Un/l, urea $12,3 \mathrm{mM} / 1$, basic phosphatase - $160 \mathrm{Un} / \mathrm{l}$, alfa-amilase - 9,1 mg/s 1 , glucose in blood - 5,5 mmol/l. Blood test for the markers of viral hepatitis: $\operatorname{HBsAg~(-),~}$ HCVAb (-). Lipidogram: LPLD - 3,54 mmol/l. Serological blood test (-). Ordinary urine test: protein - 0,678g in $650,0 \mathrm{ml}$, or $1 \mathrm{~g} / \mathrm{l}$ (normal amount - less than $0,002 \mathrm{~g} / \mathrm{l})$; erythrocytes - 8-10, transformed. Ultrasound investigation of abdominal organs: Polycystic liver. Hepatomegaly. Chronic cholecystites. Chronic pancreatitis. Polycystic kidneys. ECG: rhythm is sinusal, correct, HR-77 per 1 min. ECG-signs of left ventricular hypertrophy.

The mentioned case has been noticed when the physician was called to department of vascular neurology for consultation. The neurologist explained the patient's diagnosis that was confirmed by CT and could not be unclear. The patient's granddaughter, the doctor herself, was present in department and worried about the excessively high AsAT and AlAT's levels at her grandmother. The test could not be unclear as it was doubled: AlAT - 340,6 Un/1 (normal 0-36 Un/l), AsAT- 805,0 Un/1 (normal 0-34 Un/l). Taking the case history the physician has got information that both members of family, the patient's son and granddaughter suffer from Gilbert's syndrome.

The results of ultrasound investigation of abdominal organs and kidneys. Liver, right lobe - 17,9 cm (normal size $14-15 \mathrm{~cm}$ ), left lobe $-5,8 \mathrm{~cm}$ (normal 3$4 \mathrm{~cm}$ ), square lobe $-5,8 \mathrm{~cm}$. There are multiply cysts in the left lobe, their diameters are equal from $1,0 \mathrm{~cm}$ till $2,3 \mathrm{~cm}$; the cysts' diameter in the right lobe $4,8 \mathrm{~cm}, 9,6 \mathrm{~cm}, 1,9 \mathrm{~cm}$; vena porta $1,0 \mathrm{~cm}$, diffusely tight. On the border of right lobe and left lobe - Echo (-) $2,5 \mathrm{~cm}$. There are calcinates in the liver's structure. Gallbladder: V-29ml, no stones, the cervix is bent. The walls are tight. Pancreas hyperechogenic diffusely, the head $2,5 \mathrm{~cm}$, the body $2,5 \mathrm{~cm}$, the tale $2,7 \mathrm{~cm}$. The spleen - ordinary. Right kidney - 11,1 x 15,2cm, parenchyma 1,0cm, in parenchyma there is Echo (-) $1,8 \mathrm{~cm}$ in diameter, in the middle segment there is a group of Echo (-) 1,5-1,8cm in diameter. Left kidne11,5 x 15,7cm, parenchyma $1,0 \mathrm{~cm}$, in the middle segment there are the cysts $2,2 \mathrm{cmm}, 2,0 \mathrm{~cm}, 2,8 \mathrm{~cm}$, in the kidney's gate there are Echo (-) 6,0-4,3 cm, and there are calcinates in parenchyma. Conclusion: Polycystic liver. Hepatomegaly. Chronic cholecystites. 
Chronic pancreatitis. Polycystic kidneys. The structural changes of liver and renal parenchyma.

Results and discussion. When it is difficult to make the diagnosis I read the laboratory tests again. So, in urine test: protein $-0,678 \mathrm{~g}$ in $650,0 \mathrm{ml}$ or $1 \mathrm{~g} / \mathrm{l}$ (normal - less than $0,002 \mathrm{~g} / \mathrm{l}$ ); erythrocytes $8-10$, transformed. Not only protein had been filtrated into urine, but the red blood cells also. At the same time, creatinin's level is normal. And there was no one renal disease in the past. Except polycystic kidneys. And I start thinking about that renal cysts - in case of an extreme their thinning due to long-termed intake of Paracetamol - does hematuria could be appeared? Yes, it could be possible. When the cyst is bordering on renal pelvis, glomerule, tubule, per diapedesum. And an increased AsAT could confirm such suggestion? Yes.

Return to liver now. Syndrome of megacytolysis means for the hepatocytes, first: hepatic coma, necrosis. But the patient is active. Secondly, at the patient should develop hepatic jaundice but her skin, visible mucous membranes, urine and feces are naturally colored and bilirubin's level is normal. Thence, I make conclusion: cytolis could not has come from hepatocytes. In the hepatic cysts (their amount was huge, doctor could not calculate them exactly, the maximal cyst reached $9,6 \mathrm{~cm}$ in diameter) took place the same pathological thinning of their mucous membranes that demonstrated itself by syndrome of megacytolysis, super-high AsAT. (Ivashkin V.T.,2009; Perederii V.H.,2012).

An increased level of basic phosphatase $160 \mathrm{Un} / 1$ (normal 42 -141 Un/l) does confirm the syndrome of intra-hepatic cholestasis due to presence of multiply cysts in the liver (Andruschenko E.V., 1985; Mostovyi Yu.M.,2009).

More side effects of Paracetamol have been found: thrombocytopenia $176 \mathrm{~g} / \mathrm{l}$, the increased levels of alfa-amylaze - 9,1 мг/с л (normal 3,3-8,9 mg/c l) and urea 12,3mM/1 (while normal range 2,5-8,2 mM/l) ( Ivashkin V.T.,2009; 2010).

The physician prescribed Heptral 400mg, dissolved in 5,0ml standard solvent, intravenously slowly, the first 5 days, the next 20 days - Tab. Heptral 400mg, 1 tablet twice per day. (Iurev K.L.,2012; Babak O.Ya.,2015).

The patient was discharged from hospital with improvement. The levels of AsAT and AlAT were nomal, AsAT-25,0 Un/1, AlAT- 36,0 Un/l. 
Conclusion. The side - effects of Paracetamol have appeared at the patient V., after a year of Paracetamol's uncontrolled intake: syndrome of megacytolysis, syndrome of cholestasis; the increased levels of alfa-amylaze and urea; thrombocytopenia; proteinuria, hematuria.

\section{References:}

Andruschenko E.V. (1985) Differential-diagnostic reference book of therapist. Kiev, "Zdorov'ya", 295s.

Babak O.Ya., Lapshina E.A., Babak M.O., Chernyak A.N. (2015) Liver disease treatment strategy. The role and place of ademetionine from the perspective of evidence-based medicine. Suchasna gastroenterologIya, 1,30-33.

Ivashkin V.T., A.O.Bueverov. (2010) Pathogenetic and clinical rationale for the use of ademetionine in the treatment of patients with intrahepatic cholestasis. Zdorovya Ukrainy, 4, 3-4.

Ivashkin V.T., Bueverov A.O.(2009) Ratsionalnaya farmakoterapiya $v$ gepatologii. Moskva, "Literra"293s.

Mostovyi Yu.M.(2009) Rational pharmacotherapy in hepatology. (11-nd ed.). Vinnytsia, DP “DKF”, 524s.

Perederii V.H., Tkach S.M.(2012) Practical gastroenterology. Vinnytsia, Nova knyha, $729 \mathrm{~s}$.

Iurev K.L. (2012) Heptral (ademethionine) is a hepatoprotector and antidepressant. Ukrainskyi medychnyi chasopys, 1 (87), 1-11 


\section{Perinatal psychological support, counseling and education \\ Natalya Guba, Natalya Mosol \\ Zaporizhzhia National University, Zaporizhzhia, Ukraine}

Introduction. Perinatal mental health has become a significant public health concern. Recent studies and Mental Health surveys in many countries indicate growing demand for psychological support during pregnancy and postpartum period. Up to one in five women and one in ten men are affected by mental health problems during pregnancy and the first year after birth (the perinatal period). Women usually feel more vulnerable and anxious, and some may develop depression. Without appropriate diagnostic, assessment and support, the negative impact of mental health problems during the perinatal period can have long-term effects and influence not only women, but their partners and children too. The emotional and mental wellbeing of a pregnant woman are main factors determening the healthy pregnancy and well-being of a child after birth. Mental health issues can impact on a mother's ability to bond with her baby and to respond to the baby's emotions and needs.

Perinatal counseling can be applied as early intervention for new and expectant mothers and their families. It's also important to provide parental education. Psychological and pedagogical studies conclude that young families have difficulties with the childcare and majority of parents know little about how children grow and develop. Supporting the mother (and father as well as other family members) and the developing infant through perinatal period is recognized to be a key time for intervention in order to mitigate the negative outcomes.

Purpose. To establish a scientific basis for perinatal psychological support as an important part of perinatal care, to analyze existing perinatal practices, and to describe content and features of perinatal psychological support.

Approach A theoretical review of perinatal support was done. "To support" means to accompany somebody at certain life stage or in certain life situations. The important goal of psychological perinatal support is promotion of health and well-being of a woman and a child. Theoretical and practical issues of perinatal psychology were developed by D. Chamberlain, N. Fodor S. Grof, E. Paul, T. Vernie, S. Ward. Development of perinatal psychology practices in Ukraine was strongly impacted by psychology of parenthood and reproductive psychology (G. Filippova), perinatal psychotherapy (I. Dobryakov), transpersonal directions of perinatal psychology (G.Brekhman), resource psychotherapy (N. Kovalenko), practice of preparation for parenthood (M. Lantsburh, I. Bratus') and others. The analysis of perinatal practices was done on the basis of the data collected. The program of perinatal psychological support was approbated.

Appropriate diagnostic and assessment can help family physician, gynecologists, and psychologists or psychotherapists to determine and to take into consideration psycho-emotional state of pregnant in order to provide the woman with timely, qualified psychological support. The described below diagnostic tools can be applied for assessing psycho-emotional state of pregnant woman: Individual Typological Questionnaire (ITQ) by L. Sobchik, Personality Questionnaire of Bekhterev Institute (PQBI), Eysenck Personality Questionnaire (EPQ), Strelau Temperament Inventory (STI), Taylor Manifest Anxiety Scale (TMAS), Taylor Manifest Anxiety Scale (TMAS), Test of self- 
esteem evaluation of differential functional state (well-being, activity, mood), Zung Self-Rating Depression Scale, The Perceived Stress Scale (PSS), Test of attitude to pregnancy by I. Dobryakov, Marital Satisfaction Questionnaire, Projective method "Me and my child" by G. Filippova). These diagnostic tools have been used to evaluate the effectiveness of the approbated program of perinatal support.

Results. Perinatal psychological support is a complex of measures aimed at providing psychological assistance to women and families at the stage of planning pregnancy, during pregnancy and after birth of a child. The psychological support of women and families during pregnancy, childbirth and during the first year after birth is the main goal of perinatal psychology. Practice of perinatal psychology combines the following activities: perinatal psychological diagnostics, psychotherapy, psychological correction and prevention. The practical tasks of perinatal psychology include optimization and correction of actual problems of mental and physical reproductive health of parents and child development; preparation of couples for conception, pregnancy and childbirth; parental education; early prevention of medical and psychological disorders.

Perinatal care is aimed to protect the health of mothers during pregnancy, childbirth and postpartum period and to ensure healthy neonates. Perinatal care includes having access to a range of good-quality information and services: family-planning counseling, information, education, communication and services, including access to safe and effective contraceptive methods; education and services for prenatal care, safe delivery and post-natal care, parental education. The human, clinical and financial case for ensuring women have access to timely and effective perinatal support during the perinatal period is clear and compelling. Complex support of pregnant women and their families should be provided by team of specialists (gynecologists, psychologists, psychiatrists, pediatricians). The System of Perinatal Care has gaps in providing psychological support. In Ukraine work with the family expecting child is mostly medically-centered. Future parents don't have complex support (especially psychological assistance) during pregnancy, childbirth and first year(s) after birth. There is also lack of parental education programs.

The main areas of existing perinatal practices are: perinatal education (training of future parents, preparation for childbirth and parenthood, forming of parental awareness), individual and family counseling and psychotherapy, psychological assistance. Psycho-correction work helps future mothers to prepare for psycho-physiological maternity stress, forms readiness for motherhood, and promotes the development of parenting competence. Different diagnostic methods are actively used for determining the level and dynamics of anxiety, the type of pregnancy, the attitude toward parenthood.

So far the important tasks of perinatal psychological support are: educational work, formation of readiness for future parenthood, development of parental competence, correction of the psycho-emotional state of pregnant woman, harmonization of relations in the family, establishing positive parentchild relationship. The critical importance of the early years for lifelong health, learning and behavior, and the recognition of parents as children's first teachers are foundational concepts in providing the effective family services and parental education. The analysis of international and Ukrainian practices shows that both state and public services can provide effective programs for families and parents. 
In Ukraine perinatal counseling and parental education are provided by such agencies as Social Services for Family, Children and Youth, Centers for Reproductive Health and Family Planning, Schools of Conscious Paternity at the Antenatal clinics. In recent decades local family centers and non-governmental organizations have emerged to run such services (Associations of Conscious Parents, Community-based Family Centers etc).

Limitations and strengths of the study. It is important to evaluate the impact of perinatal psychological support and to count the cost of undiagnosed or untreated perinatal mental health issues and potential economic benefits of perinatal psychological support. A comprehensive inventory should be used to identify gaps in existing services of perinatal care system and areas of need.

The future prospect of our research is to investigate the impact of psychoemotional state of pregnant on the personal well-being of a woman and a child.

Practical and social value. Early diagnostic and adequate treatment of perinatal mental health issues is crucial and economically reasonable. Effective perinatal support during pregnancy and the early postpartum together with facilitating transition to parenthood has the potential to promote more healthy individuals, families, communities and societies.

Conclusions. The findings of the research open up the possibility to provide better value, evidence-based perinatal support. So far, perinatal period can be defined as the start determining the potential of human health. Pregnancy and the postnatal period therefore provide the ultimate opportunity for preventative care to improve well-being of woman, children and families. The Perinatal Care System has gaps in providing psychological support. Analysis of perinatal psychology practices makes it possible to determine the following forms of prenatal psychological support of women and families: preparation for childbirth and parenting; individual and family psychological counseling and psychotherapy, psycho-correction work, parental education.

Pregnant women and future parents should have more psychological support across maternity services and mental health settings. The promotion of perinatal health requires coordination and collaboration among national agencies, institutions and professionals at both state and local levels.

Keywords: perinatal period, pregnancy, perinatal psychology, psychological support, perinatal counseling, parental education. 


\title{
Parameteres of mental health in childhood
}

\section{Параметри психічного здоров'я в дитинстві}

\author{
Elena Kazannikova \\ Олена Казаннікова
}

Kherson State University, Herson, Ukraine

Херсонський державний університет

У сучасному суспільстві, де щороку посилюються вимоги до маленької особистості, проблема психічного здоров'я привертає увагу дослідників із різних галузей науки i практики. Аналіз становлення повноцінної особистості вказує на те, що часто деформації розвитку особистості беруть свій початок в дитинстві. Саме діти потребують уваги, оскільки соціально-політичні кризи суспільства завдають шкоди психічному здоров'ю підростаючого покоління.

Термін «психічне здоров'я» неоднозначний, і перш за все як би пов'язує дві галузі науки і практики - медичну і психологічну. Психічне здоров'я - елемент здоров'я в широкому сенсі. Здоров'я розглядають як багатомірний феномен, який має гетерогенну структуру, сполучає в собі якісно різні компоненти і відображає фундаментальні аспекти людського буття. Психічне здоров'я - це не просто відсутність недоліків, а й наявність ряду достоїнств у структурі особистості. Терміном здоров'я позначають стан повного душевного, фізичного і соціального благополуччя, а не тільки відсутність хвороб і фізичних дефектів [4].

Основними параметрами психічного здоров'я вважають:

1. Пристосування до соціального і природного оточення - можливість не тільки пристосуватися до існуючих умов, але й активно перетворювати ïx.

2. Нормальність - як відповідність соціальним і культурним нормам (соціокультурна характеристика здоров'я, загальна для представників даного соціуму).

3. Стресостійкість і стабільність людини в процесі активної взаємодії 3 оточуючим світом.

4. Гармонійна включеність у спільність людей, результатом чого $є$ соціалізація дитини.

Психічне здоров'я можна визначати як відсутність виражених психічних розладів, як визначений резерв сил людини, завдяки якому вона може подолати неочікувані стреси. Психічне здоров'я - це сукупність установок, якостей і функціональних здібностей, які дозволяють індивіду адаптуватися до середовища [3].

Головний критерій оцінки психічного здоров'я, оптимального функціонування особистості - це характер і ступінь включеності індивіда у зовнішні біологічні і соціальні системи. 3 одного боку, мається на увазі такий рівень природних задатків людини, при якому забезпечується виживання і пристосування до оточуючого природного середовища. 3 іншого боку, мова іде про ступінь сформованості їі соціальних стосунків та 
мірі відповідності іiі поведінки основним нормам i вимогам соціуму. Психічне здоров'я свідчить про динамічну рівновагу індивіда 3 оточуючим середовищем, таке функціонування психіки індивіда, яке забезпечує йому гармонійну взаємодію зі світом. Психічне здоров'я людини характеризується іiі можливостями адаптації, соціалізації та індивідуалізації. Таким чином, психічне здоров'я, $\epsilon$ умовою адекватного виконання людиною своїх вікових i соціокультурних ролей, 3 іншого, забезпечує людині можливість безперервного розвитку протягом всього життя. Збереження фізичного і психічного здоров'я особистості, зокрема підростаючої - одне 3 най важливіших завдань суспільства i, насамперед, освіти [4].

Стан психічного здоров'я дитини пояснюється умовами іiі психосоціального розвитку. Основними показниками сформованості психічного здоров'я у дітей дошкільного віку є:

процес адаптації після вступу до ДНЗ;

рівень розвитку комунікативних навичок;

рівень позитивної мотивації до соціально важливої для даного віку діяльності;

відсутність відхилень у поведінці.

В ряді психологічних робіт психічне здоров'я співвідноситься 3 переживанням психологічного комфорту й психологічного дискомфорту. Будь-яка ситуація стає важкою, дискомфортною, коли виникає невідповідність між іiі основними елементами: потребами людини, піi можливостями та умовами діяльності. Дискомфортна ситуація завжди характеризується невідповідністю між чого людина прагне, і тим, що вона може, опинившись у даних обставинах. Така невідповідність перешкоджає досягненню поставленої мети, що детермінує виникнення негативних емоцій, які і є індикатором дискомфортної ситуації для людини. Існує дискомфорт і у дітей. Враховуючи таке розуміння дискомфортної ситуації, можна передбачити, що для розвитку дитини вони $\epsilon$ типовими. Це зумовлено тим, що дитина пізнає та засвоює навколишній світ, але ще не володіє достатнім досвідом для розуміння невідомого, неочікуваного для неї, що обов'язково виникає в процесі пізнавальної діяльності. Це вимагає від неї випробування власних можливостей і здібностей, що не завжди може бути успішним і тому може стати приводом для розачарувань. Все це при визначених умовах може несприятливі наслідки для розвитку особистості дитини. Психологічний дискомфорт у дитини може виникнути в результаті фрустрацій іï потреб, що може зумовити психогенну дезадаптацію, депривацію. Фрустрація однієї чи декількох потреб дитини лежить в основі неврозів, які проявляються у вигляді різноманітних захворювань психосоматичного генезу. Дослідники відзначають, що найбільш суттєво впливають на дітей гострі психічні травми та хронічні психотравмуючи впливи, які є ситуаціями підвищеного ризику і спричиняють виникнення дезадаптивних реакцій. Аналіз таких ситуацій, проведений спеціалістами, показує, що у дітей різного віку ці ситуації розрізняються за змістом. Для дошкільного віку найбільш характерними виявляються психотравмуючи ситуації, пов'язані із втратою (реальною чи уявною) почуття захищеності [2].

Порушення психічного здоров'я найчастіше спостерігається у дітей, які страждають від недостатнього спілкування з дорослими або їх ворожого 
ставлення, а також у дітей, які знаходяться в умовах сімейних розладів. Дитинство характеризується сильною емоційною прихильністю до батьків, особливо до матері, тому конфлікти між батьками, неадекватний стиль виховання, характер взаємостосунків у родині викликають у дітей постійне відчуття неспокою, невпевненості у собі, емоційне напруження і можуть стати джерелом психічного нездоров'я. Сильною психотравмуючою подією для дитини є розлучення з матір'ю, зумовлене ії раннім виходом на роботу, це збільшує потребу дитини в іï прихильності і може спричинити фобії, негативізм, невротичні реакції. Означені ситуації, суттєво впливаючи на весь хід психічного розвитку, здатні порушити соціальну адаптацію дитини, деформувати її психіку [1].

У психологічній літературі виділені і достатньо проаналізовані фактори, які впливають на психічне здоров'я дитини. Більшість 3 цих факторів носять соціально-психологічний, соціально-культурний та соціально-економічний характер. Розвиток дитини, ऑiї психічних й особистісних якостей багато в чому визначається тими взаємостосунками, які створюються між особистістю, що формується, і найближчим дорослим оточенням.

\section{Література:}

Мамайчук I.I. Діти з розладами поведінки: психологічна допомога / I.I. Мамайчук. - К.: Редакції загально педагогічних газет, 2012. - 120с.

Проценко О.В. Профілактика соціальної дезадаптації дошкільнят / О.В. Проценко. - К.: Шкільний світ, 2011. - 128c.

Психологічне здоров'я дошкільників / Уклад. Т.І. Прищепа. - Основа, 2010. $-239 \mathrm{c}$.

Терещенко Л.А. Як зберегти психічне здоров'я дітей 5-7 років / Л.А. Терещенко. - 2012. - 104c 


\section{Psychological bases of human health}

\section{Психологічні основи здоров'я людини}

Mykola Kostenko

Микола Костенко

Національний університет біоресурсів і природокористування України, Київ, Україна

Хотя человеческой жизни нет цены, мы всегда поступаем так, будто есть нечто более ценное.

Антуан де Сент Экзюпери.

Перед кожним поколінням постають питання таємниці і сенсу людського буття. Незнання або нерозуміння об'єктивних закономірностей свідомості, психіки, моральних основ, які управляють людським життям часто призводять до складних життєвих ситуацій з яких важко знайти вихід. Темп життя, сучасні швидкості і технології виявилися психологічно, а часто i фізіологічно не прийнятними для більшості людей. Агресивність навколишнього середовища і перевага негативних емоцій призводять до того, що майже всі хвороби які переносить сучасна людини протягом життя мають один корінь - стрес.

Наш час характеризується збільшенням захворюваності від звичайної неврівноваженості до тяжких душевних депресій. Останні статистичні дані MO3 України свідчать про збільшення кількості психічно хворих. Це число на сьогодні становить 1,5 млн. осіб (це тільки офіційна статистика), дані неофіційної - набагато тривожніші [1, 57]. Одні стреси накладаються на інші провокуючи внутрішньо-особистісні конфлікти. Спостерігаються системні захворювання організму, що проявляються в різних формах. Людина зношується, передчасно старіє - це викликає в кінцевому результаті хвороби душі і тіла.

Можна сказати, що всі ми сьогодні переживаємо кризу адаптації, яка більшою мірою залежить від психічних можливостей людини. Наше ставлення до життя часто межує 3 відчуттям неспроможності щось змінювати. Для деяких людей життя суцільні розчарування, для інших постійна біль. Результатом такого становища часто буває відмова від активного життя. $€$ цікава східна мудрість: „Найгірша хвороба - втома від життя". На сьогодні кількість втомлених, незадоволених, депресивних, тривожних, переляканих катастрофічно збільшується. Адаптивність людей різна і обумовлена багатьма вродженими і набутими якостями (це стійкість до невдач, витривалість, комунікативність, психічна i фізична гармонія i навіть зовнішні дані). Молодь, яка $\epsilon$ індикатором суспільних процесів, ще гостріше відчуває дисгармонійність буття. Багато з нас роблять ті ж самі помилки 3 постійною періодичністю. При цьому ми переконані в своїй правоті, і вважаємо, що повторення тих самих вчинків достатньо для того, щоб оточуючі зрозуміли істинність нашої позиції і змінили свою поведінку. Ми хочемо, щоб життя змінилося при цьому не бажаємо змінюватися особисто. Однак для того, щоб змінити іншу людину насамперед треба 
змінитися самому.

Існують універсальні закони буття, суть яких полягає в унікальності самоідентифікації людини. До індивідуальних форм прояву відносять особливості просторово-часових характеристик процесів, характер міжособистісних стосунків, усвідомлення функцій і життєвих ролей, та певна швидкість їх реалізації [2]. Людство розвивається в напрямку організації первинного хаосу, що проявляється в двох основних позиціях: розвиток особистості i розвиток соціуму. Даний принцип розвитку розкривається в контексті дуальності (два типи темпераменту, які задають або точку відліку, або систему обмеження часу, два типи моралі, що обумовлюють або прив'язку до природного часу, або задають рамки соціального часу). Перше пов'язано 3 конфліктами, обумовленими особистісним зростанням, проблемами поєднання свідомого і несвідомого, внутрішнього i зовнішнього. По ідеальній схемі, людина розвивається ступенево, розширюючи свідомість і залучаючи до неї об'єкти зовнішнього і внутрішнього світу, самоорганізується, а в подальшому, виходячи 3 нових позицій, свідомість адаптується до реалій життя, після цього весь цикл повторюється знову. В реальності цей процес залишається маловивченим, але вже відомо, що для таких перетворень необхідна адаптаційна процедура і в цьому випадку конфлікти є необхідними складовими які стимулюють особистість, що саморозвивається.

Зниження показників фізичного i психічного здоров'я в загальнонаціональному масштабі призводить до того, що від покоління до покоління відбувається дегенерація енергетичних i фізіологічних потенціалів, оскільки тілесно і психічно незрілі люди схильні до народження ще більш ослаблених нащадків. Таким чином, сьогодні можна говорити про здоров'я як фактор національної безпеки і моральності.

На психічне здоров'я людини впливає багато факторів: прийняття відповідальності за своє життя і частково за своє здоров'я, психологічна самоактуалізація людини. Часто ми чуємо фразу: „, життя не склалося”, „не судьба". Позбавлені займенника ,я, ці фрази свідчать про відмову від особистої відповідальності і пасивну залежність від обставин навіть у ставленні до самого себе.

Самоактуалізація передбачає наявність „Я”. Людина - це не tabula rasa, не пластилін. Вона завжди є дещо, певна стрижньова структура: певний темперамент, біохімічний баланс і т.п. Але, на жаль, більшість 3 нас частіше прислухаються не до самих себе, а до голосу керівництва, влади, традицій, батьків, а в реальній поведінці це проявляється в тому, що ми не завжди розуміємо чи дійсно те що ми робимо нам потрібно!

Рано чи пізно ми всі усвідомимо, що всі неприємності є наслідком неуважного ставлення до себе самого та до інших людей. Формування нової системи цінностей, яка б базувалася на реальних потребах і можливостях ось шлях для гармонійного розвитку особистості.

\section{Література}

Хаустова О.О. Психосоматичні маски тривоги / О.О. Хаустова // Український медичний часопис. - 2019. - №. - 4(132), Т.1. - С.2 - 8. 
Шмаргун В.М. Когнітивно-стильові особливості дітей як прояви своєрідності індивідуального інтелекту / В.М. Шмаргун // Практична психологія та соціальна робота. - 2006. - №10. - С.10-21

(C) NDSAN (MFC - coordinator of the NDSAN), Italy, 2019 


\title{
Destigmatizing direction of psychologist's work in the field of mental health care
}

\author{
Olena Malyna \\ Zaporizhzhia National University, Zaporizhzhia, Ukraine
}

\begin{abstract}
Introduction. Currently one of the main directions of the World Health Organization's mental health program is the problem of overcoming the stigmatization of patients with mental disorders. It is particularly relevant in conditions of exacerbation of social relations and increasing of social tension when mentally ill people become the most vulnerable category of stigmatization as a negative and biased reaction to their psychiatric diagnosis and connected with it prejudgment, depreciation, alienation and, after all, discrimination. The introduction of socially oriented types of assistance to mentally ill patients requires a practical solution of the problems connected with sociopsychological rehabilitation of patients with mental disorders, the realization of which, first of all, is provided for overcoming the stigmatization and autostigmatization of people with psychiatric status.
\end{abstract}

Purpose. In Ukraine there are more than one million people who suffer from mental disorders and there is a worldwide tendency to this number growth. The stigmatization of mentally ill people becomes one of the most acute social problem which requires systematic, coherent understanding of the common interdisciplinary foundations of a task-oriented reformation of mental health care system which should be based on the principles of humanism and social justice, and on the implementation of a complex antistigmatization approach to social, psychological and medical help. So, the purpose of the article is to examine the essence and the main features of the destigmatizing direction of the psychologist's work in the field of mental health care.

Methodology / Approach. Despite the social significance of the problem and the pendency of theoretical issues, the separate studies of the influence of the sociopsychological factors on the perception of the mental health and the problems of the attitude of the society towards the patients with psychiatric status saw the light only at the end of the last century (Kabanov M.M., Abramov V. A., Mendielievych V.D., VO Chakhava, Avedisova V.I., Hurvych I.N., Yastriebov V.S., etc.) $[1,3,4,6]$. Traditionally the problem of stigmatization of the mentally ill people has been studied mainly in sociological and medico-social aspects (Hoffman's theory of spoiled identity, 1963; T. Sheff's "label" theory, 1966; Haghighat's unitary theory of stigma, 2001). So, the mechanisms of stigma's formation as a social stereotype (J. Townsend, 1979) and different social factors of the formation of stigma of mental disorder (A. Finzen, S. Sotang, K. Jones) were examined; social consequences of stigmatization (A. Tasman, 1992; J. Crocker, 2004, S. Dinos, 2004), the meat of stereotypes and ideas of different social groups towards the mentally ill people (J. Bright, 1997; J. Rabkin, 1974) were empirically determined; the influence of mental disorders on delinquent behavior (Korolov V.V., Karpets I.I., Kudriavtsev V.N.) was investigated. The mechanisms and ways of destigmatization in the context of a person-oriented model of psychiatric care were developed by such Ukrainian researchers as Abramov V.A., Riapolova T.L., Maruta N.O., Abramov O.V. [1,2,5]. However, there is an obvious shortage of systematic psychological studies of the process of formation of stigma of mental disorder, of factors and mechanisms of self-stigmatization of mentally ill patients of different nosological groups and of psychological technologies of destigmatization.

Results. Stigmatization is the result of social ascription, the projection of society's perception of unacceptable traits or patterns of behavior into an individual. Stigmatization, as a process of isolating an individual from the group (due to its deviation from the average norms), allows the group to have a stereotypical set of negative social 
reactions and, eventually, to realize the purpose of such ascription, namely to use certain social sanctions. So, there should be two conditions for stigma to appear: a parameter that discredits a person and his differences from the dominant social norm and a negative assessment of this difference by the group. These conditions lead to the evaluation of the person completely by this parameter, ignoring his integrity, personality and, eventually, dehumanizing his identity. The need for stereotypes is conditioned by the attempt to explain and justify a negative attitude towards mentally ill people, to rationalize their discrimination.

Destigmatization measures should be, first of all, aimed to overcome and to prevent the factors of stigmatization which include: 1) stereotyping of mass consciousness, manipulation of the public opinion about patients with mental disorders that are traditionally thought to be incompetent, unpredictable, dangerous, helpless, unreliable, disgusting, hostile and those which should be excluded from public life; 2) formation of a negative image of the system of psychiatric care and its opportunities in the treatment of mental disorders in general; 3) too low level of psychiatric and psychological literacy in the society which leads to the formation of negative stereotypes and to the existence of myths about mental disorders; 4) confidence in the low social significance and usefulness of patients with mental disorders, considering them as helpless, dependent and incapable; 5) a low level of social demand of patients with mental disorders, their social isolation and the isolation of their families; 6) a low level of tolerance, empathy, the desire to distance oneself from the mentally ill people and exclude them from social interaction; 7) the discrimination of patients with mental disorders, a lack of job quotas in the labor market, a lack of training and retraining opportunities, complications in the process of rehabilitation and self-realization of patients due to the changes in socio-economic situation in the country.

When psychologist works directly with patients and their families that are stigmatized, he should be aimed to 1) form a stable and consistent self-concept, help to reveal patient 's resources, life goals and build their future perspectives; 2) correct the inadequate attitude and perceptions of their mental state, limitations and possibilities; 3) actualize healthy components of mental activity, increase patient's self-esteem, correct patient's destructive identity; 4) correct negative emotional experiences and internal conflicts, form the skills of emotional self-regulation and emotional support within a family; 5) form a coordinated motivational system and mobilize the efforts to overcome the limitations caused by mental disorders; 6) create new behavioral strategies for achieving goals and overcoming auto-stigma and self-isolation; 7) form constructive identity of the mentally ill person.

Practical / Social value. The implementation of socio-oriented types of assistance to the mentally ill people cause the need for further theoretical and empirical study of the problem of stigmatization which will allow to make the program of antistigmatization intervention better, to optimize social integration of patients with psychiatric disorders, to improve the system of their social care and psychological maintenance, to contribute to the effective solution of problems connected with rehabilitation of patients with mental disorders.

Conclusions. Destigmatization, as a process of mitigating of the impact of the stigma of psychiatric illness and prevention of deformation of the personal and social identity of patients, should take into account the principles of activity and publicity, it should have a clear personal and value-humanistic orientation and be focused on the existentially personal rehabilitation of patients, recurrence of their capacity to realize their professional and social potential, restoration of their social status, subjective well-being and quality of life. 
Keywords. Stigma, stigmatization, mental health, discrimination, destigmatization, social distancing, future perspective, identity, patients with mental disorders.

\section{References.}

Abramov V.A. Эffektы sty`gmaty`zacy`y’ y`autosty’gmaty`zacy`y` bol`nыx na razly`chnыx stady`yax shy`zofreny`y`/ V.A. Abramov, T.L. Ryapova, A.V. Abramov// Ukrayins`ky`j visny`k psy’xonevrologiyi. - 2008.- \#2 (55). - S. 27-32

Gurovy`ch Y'. Ya. Socy’al’naya psy`xology'ya zdorov'ya/ Y`.Ya. Gurovy`ch// Russky’j medy`cy`nsky`j zhurnal. 2001. T.9 \#25, - S. 38-51.

Eny`kopolov S.N., Meshkova N.V. Napravleny`ya y`ssledovany`ya predubezhdennosty` v zapadnoj psy`xology`y` mezhgruppovыx otnosheny’j. / S.N. Eny`kopolov, N.V. Meshkova //Voprosu psy’xology`y’. 2007, - \#1 - , S.148-158.

Kabanov M.M., Burkovsky’j G.V Redukcy`ya sty'gmaty'zacy`y` y’ dy`skry`my`nacy`y psy`xy'chesky' bol'nыx. ./ M.M. Kabanov, G.V.Burkovsky'j// Obzor psy'xy’atry'y'y' medy`cy`nskoj psy`xology`y'. 2000, - \# 1, - S 3-8.

Maruta N.O., Abramov V.A, Ryapolova T.L., Abramov O.V. Sy`stematy zaciya peredumov i mexanizmiv formuvannya sty`gmy`u xvory`x na psy`xichni rozlady`. Metody`chni rekomendaciyi/ N.O. Maruta, V.A. Abramov, T.L. Ryapolova, O.V. Abramov// DNMU im.. M. Gor`kogo, 2011, $28 \mathrm{~s}$.

Phelan J, Link BG, Dovidio JF. Stigma and prejudice: one animal or two? Social Science \& Medicine.2008; 67:358-367

Keywords. Stigma, stigmatization, mental health, discrimination, destigmatization, social distancing, future perspective, identity, patients with mental disorders

(C) NDSAN (MFC - coordinator of the NDSAN), Italy, 2019 


\title{
PECULIARITIES OF INDIVIDUAL INDICATORS OF COLLAGEN METABOLISM AND LEVEL OF MATRIX METALLOPROTEINASE-9 IN CASE OF GASTROESOPHAGEAL REFLUX DISEASE IN PATIENTS WITH SYNDROM OF UNDIFFERENTIATED CONNECTIVE TISSUE DYSPLASIA
}

\author{
Iryna Romash \\ Department of Propaedeutics of Internal Medicine, Ivano-Frankivsk National Medical \\ University (IFNMU), Ivano-Frankivsk, Ukraine
}

\begin{abstract}
The objective of the research was to study the prevalence of phenotypic and visceral markers for the syndrome of UCTD in patients with gastroesophageal reflux disease (GERD) and the nature of changes individual indicators of collagen metabolism and level of matrix metalloproteinase-9 (MMP9).
\end{abstract}

Materials and methods. The study included 120 patients: 75 patients (Group II) GERD was on the background of UCTD, 45 (Group I ) - the patients with GERD. The control group consisted of 12 practically healthy persons, without signs of UCTD. The average age of the patients was $42.0 \pm 6.5$ years. Evaluations of UCTD's were performed accordingly to the criteria recommended by $\mathrm{M}$. Moska et al., A. Doria et al., T. I. Kadurina, L. M. Abbakumova in the modification of T. Milkovskaya-Dimitrova, and the degree of their expression on the scale of T. Y. Smolnova. Concentration of oxyproline (OP) in blood serum and daily portion of urine was determined by photocolorimetric method. Matrix metalloproteinase-9 in serum was tested by immunoassay method.

Conclusions: In adults with GERD in the background of UCTD, arthralgia, Raynaud's phenomenon, reduced body mass, bone, articular and skin phenotypic signs correlating with the frequency and duration of GERD, and treatment tactics of such patients should take into account these changes.

Key words: gastroesophageal reflux disease, undifferentiated connective tissue dysplasia, visceral and phenotypic markers, oxyproline, matrix metalloproteinase-9.

Introduction. Undifferentiated connective tissue dysplasia (UCTD) is characterized by the signs reflecting the systemic autoimmune process which does not correspond to any accepted diagnostic criteria for diseases such as rheumatoid arthritis, Sjogren's syndrome, systemic scleroderma, polymyositis and dermatomyositis, systemic lupus erythematosus, and mixed connective tissue diseases (Doria A.,2005; Mosca M, et al.,2014; Ferri et al.,2016; Antunes M. et al., 2018). Also, at the moment, the UCTD is considered as a basis that identifies the features of the course of the associated pathology and the tendency to chronisation the latter, frequent relapses, determines the peculiarities of approaches to the treatment of such combined pathology and its effectiveness. The digestive system is the second by the highest level of collagenization after the cardiovascular system, changes in it are particularly often observed in case of UCTD (Nica A. E.,et al., 2016). It causes changes in the length and size of the digestive system and the esophagus first of all, which is likely to be due to its mesenchymal origin (Bodolay E., et al., 2003). At the same time, the 
manifestations and mechanisms of formation of comorbidity UCTD and GERD in adults have not been sufficiently studied.

The objective of the research was to study the prevalence of phenotypic and visceral markers for the syndrome of UCTD in patients with gastroesophageal reflux disease (GERD) and the nature of changes individual indicators of collagen metabolism and level of matrix metalloproteinase-9 (MMP-9).

Materials and methods. The study included 120 patients: 75 patients (Group II) - GERD was on the background of UCTD, 45 (Group I ) - the patients with GERD. The control group consisted of 12 practically healthy persons, without signs of UCTD. The average age of the patients was $42.0 \pm 6.5$ years.

In addition to traditional general clinical and general laboratory methods, all patients purposefully searched for phenotypic and visceral signs of UCTD syndrome according to the criteria recommended by M. Moska et al., A. Doria et al., T. I. Kadurina, L. M. Abbakumova in the modification of T. MilkovskayaDimitrova (Doria A.,2005; Mosca M, et al.,2014; Soleiko O. V.,2014; Antunes M. et al., 2018). We used T. Yu. Smolnova scale in order to assess the aggregate and severity of CTD clinical manifestations. We also determined the presence of signs of hypermobility of the joints according to the Baiton criterion on a point scale, where one point is the presence of pathological overgrowth in one joint on one side. If 4 to 9 points are detected, hypermobility is established. Concentration of oxyproline (OP) in blood serum and daily portion of urine was determined by photocolorimetric method. Matrix metalloproteinase- 9 in serum was tested by immunoassay method.

The study was approved by the Bioethics Committee of the IvanoFrankivsk National Medical University, and conducted in accordance with the principles of the Declaration of Helsinki. Prior to the start of the study, all patients signed informed consent.

Results: Accordingly to the obtained data, in patients of Group II, the next signs of UCTD as the Raynaud's phenomenon are found in more than 2.1 times, arthralgia - in 6.4 times, dysphagia -in 1.9, periodic skin rashes -in 3.2 times, ulcers of the mucous membrane of the oral cavity - in 3.7, as among patients of Group I. It must be noted more frequent development of proximal muscular weakness in the patients of the Group I. At the same time, in $88.0 \%$ of patients of the II Group were revealed abnormalities in the development of internal organs, while in the patients of Group I - only in $6.6 \%$. Nephroptosis and kidney dystopia were found in $46.6 \%$ of patients with comorbidity and in $15.5 \%$ of patients with independent GERD. As for the patients of the Group II, there were abnormalities more often $(86,6 \%)$ in the development of gall bladder, while in the patients with GERD only in $11,1 \%$.

Analysis of transnasal daily monitoring of $\mathrm{pH}$ in the lower third of the esophagus in patients with GERD and when combined with UCTD showed that reflux with a $\mathrm{pH}<4$ was recorded in $26.6 \%$ of patients of the Group I, and their number was $57 \pm 8$ episodes, with a total duration of $67 \pm 3$ minutes, which is $4.6 \%$ of the total monitoring period. In $60.0 \%$ of patients in Group II the number of acid reflux was $79 \pm 6$ episodes, total duration $87 \pm 8$ minutes, 5.48\%. The mean De Meester was $23.01 \pm 2.24$ for the GERD patients and $31.08 \pm 2.4$ for the patients with the combination of GERD with UCTD ( $\mathrm{p}<0.05)$. An increase in the percentage of time with $\mathrm{pH}<4$ in the lower third of the esophagus in the standing and lying position was also found, respectively, in $12.3 \%$ and $7.4 \%$ of patients 
with combined pathology, whereas in GERD without concomitant pathology, $10.2 \%$ and $5.8 \%$, respectively. According to the results of correlation analysis, there is a direct relationship between the number of refluxes with $\mathrm{pH}<4$ lasting more than 5 minutes and the level of oxyproline (OP) in the daily portion of urine $(\mathrm{r}=0.66)$ and between the number of refluxes $\mathrm{pH}<4$ lasting more than 5 minutes and the level of OP in serum $(r=0.79)$

The level of OP in blood serum and in daily portion of urine in patients of Group I is not different from healthy ones, but is lower in 1.7 times compared with Group II. The content of OP in patients Group II was higher by 2.9 times compared with the control group, and compared to the Group I, it was in 3.89 times higher $(\mathrm{p}<0.05)$. Concentration of MMP-9 in patients Group I was higher in 1.9 times, and in Group II - in 2.4 times compared with the control group (p $<0.05$ ). Since oxyproline plays an important role in the stabilization of the secondary structures of collagen, determining its content in serum and daily urine can be considered as a marker of the breakdown of connective tissue components. Increasing the level of MMP-9 is able to enhance the hydrolysis of type IV collagen and lead to cardiac sphincter deficiency, as evidenced by the direct correlation between the number and duration of reflux and connective tissue markers.

Conclusions: The obtained data indicated that the number of pathological GER was significantly higher in the setting of comorbidity. In adults with GERD in the background of UCTD, arthralgia, Raynaud's phenomenon, reduced body mass, bone, articular and skin phenotypic signs correlating with the frequency and duration of GERD, and treatment tactics of such patients should take into account these changes.

\section{References:}

Antunes M, Scirè CA, Talarico R. et al.(2018) Undifferentiated connective tissue disease: state of the art on clinical practice guidelines. $R M D$ Open,4:e000786. doi:10.1136/rmd open-2018-000786.

Corte TJ, Copley SJ, Desai SR, et al. (2012) Significance of connective tissue disease features in idiopathic interstitial pneumonia. Eur Respir J., 39(3):661-8. doi: 10.1183/09031936.00174910.

Ferri C, Manfredi A, Sebastiani M. et al. (2016) Interstitial pneumonia with autoimmune features and undifferentiated connective tissue disease: Our interdisciplinary rheumatology-pneumology experience, and review of the literature. Autoimmunity Reviews, 15 (1):61-70. doi.:10.1016/j.autrev.2015.09.003.

Mosca M, Tani C, Vagnani S. et al. (2014) The diagnosis and classification of undifferentiated connective tissue diseases. J Autoimmun., 48-49, 50-2. doi: 10.1016/j.jaut.2014.01.019.

Nica A. E., Alexa L. M., Ionescu A. O. et al. (2016) Esophageal disorders in mixed connective tissue diseases. Journal of Medicine and Life, 9(2), 141.143. PubMed Central PMCID: PMC4863503.

Bodolay E., Csiki Z., Szekanecz Z., Caramanolis G. P. et al. (2003) Five-year follow-up of 665 Hungarian patients with undifferentiated connective tissue disease (UCTD) Clinical and experimental rheumatology., 003,21, №3, 313-320.

Doria A., Mosca M., Gambari P. F. et al.(2005) Defining unclassifiable 
connective tissue diseases: incomplete, undifferentiated, or both? The Journal of Rheumatology., 32(2), 213-215.

Soleiko O. V. N. A. Rykalo, I. P. Osypenko, L. P. Soleiko (2014) The syndrome of undifferentiated connective tissue dysplasia: from the concept of pathogenesis to the treatment strategy. Vinnytsia, 2014, $168 \mathrm{c}$.

Key words: gastroesophageal reflux disease, undifferentiated connective tissue dysplasia, visceral and phenotypic markers, oxyproline, matrix metalloproteinase-9

(C) NDSAN (MFC - coordinator of the NDSAN), Italy, 2019 


\title{
PECULIARITIES OF INDIVIDUAL INDICATORS OF ANXIETY- DEPRESSIVE SYMPTOMS IN STUDENTS FROM MEDICAL UNIVERSITY IN THE PERIOD OF ALTERED PSYCHOEMOTIONAL STATUS
}

\author{
Ivan Romash ${ }^{1}$, Mukhailo Vynnyk ${ }^{1}$, Iryna Romash ${ }^{2}$, Anna Polinyk $^{3}$, Olena Yevchyk ${ }^{3}$ \\ ${ }^{1}$ Department of Psychiatry, Narcology and Medical Psychology, Ivano-Frankivsk National \\ Medical University (IFNMU), Ivano-Frankivsk, Ukraine \\ ${ }^{2}$ Department of Propaedeutics of Internal Medicine, Ivano-Frankivsk National Medical \\ University (IFNMU), Ivano-Frankivsk, Ukraine \\ ${ }^{3} 5$ year students of the Faculty of Medicine. Ivano-Frankivsk National Medical University \\ (IFNMU), Ivano-Frankivsk, Ukraine
}

\begin{abstract}
Introduction: Scientists have shown that medical training itself is a risk factor in the occurrence and maintenance of symptoms of depression

Aim: To investigate and evaluate the level of anxiety and depression among students of the Faculty of Medicine and the Faculty of Training of Foreign Citizens of IFNMU during a period of altered psycho-emotional state.

Materials and methods: To achieve the goal of the study, 106 medical students aged 19 to 25 years were questioned. In order to identify emotional disturbances, we used two clinical test methods: the Hospital Anxiety and Depression Scale (HADS) and the Montgomery-Asberg Depression Rating Scale (MADRS).

Conclusions: A study of the level of anxiety and depression among students of the medical faculty and the faculty of training foreign citizens during an altered psycho-emotional state confirms that the exams caused the appearance of protective mechanisms in the form of emotional and behavioral changes and disorders.
\end{abstract}

Key words: depression, anxiety, altered psychoemotional state.

Introduction: It is well known that medical students often encounter many difficulties during training in the medical program (Castaldelli-Maia et.al.,2012). If these difficulties are ignored, they can cause additional stress and affect their academic performance, which are already under very high pressure (Dyrbye, L.N. et.al.,2011). Stress can jeopardize future professionalism. It is also known, that stress leads to emotional disturbances and suicidal ideas (Alexandrino-Silva C. et.al.,2009). There is no doubt that the difficulties associated with academic activity affect their functioning. Scientists have shown that medical training itself is a risk factor in the occurrence and maintenance of symptoms of depression. In addition, some scientific papers reported that various processes associated with competition in admission to medical universities, the first and subsequent contacts with death, pathological processes, and fear of acquiring illnesses caused emotional experiences among medical students (Baldassin S. et.al.,2012). According to other scientific data, due to their age characteristics, students are dreamers, idealistic about studying, hard to adapt to new requirements, inadequately assess their capabilities, and even feel their own failure. As a result, dissatisfaction with 
studies is formed, indifference to their duties is growing. There are signs of depersonalization, indicating the development of emotional burnout, depression. Especially often depression and emotional burnout are common among those studying in the medical specialty. Sergio Baldassini (2012), leading a team of scientists who conducted a study of 481 medical students at a private medical school in Brazil, notes that they often suffered from depression, especially during the internship. In his research, he revealed the extent of this problem and made a detailed analysis of the symptoms. According to Baldassini, "often before going to practice students are afraid that they" know nothing "and are not sure about the physical examination of other people" (Baldassin S. et.al.,2012).

The objective of the research was to investigate and evaluate the level of anxiety and depression among students of the Faculty of Medicine and the Faculty of Training of Foreign Citizens of IFNMU during a period of altered psycho-emotional state.

Materials and methods: To achieve the goal of the study, 106 medical students aged 19 to 25 years were questioned, among them 26 young men and 80 girls. Students were surveyed in the spring and winter, during the preparation of students for tests, exams, final module controls, that is, during a period of altered psychoemotional state. We studied the effects of intensified learning on student anxiety and stress. During the study, the ethical principles of the Helsinki Declaration of the World Medical Association were adhered to. Testing was exclusively voluntary. In order to identify emotional disturbances, we used two clinical test methods: the Hospital Anxiety and Depression Scale (HADS) and the Montgomery-Asberg Depression Rating Scale (MADRS) (Zigmond A.S. et.al., 1987; Svanborg P. A. et.al.,2001) .

Results and discussion. After a survey and analysis of the results on the HADS and MADRS scales, we found a clear correlation between increased learning during an altered psycho-emotional state and the severity of anxiety-depressive symptoms in medical students, which was manifested by an increase in anxiety and different degrees mood disorders .

Based on the results of the survey on this scale, during the period of the altered psychoemotional state, the normal level of anxiety-depressive symptoms (0-7 points on the scale) was found in $18.43 \%$ of students of the medical faculty and in $33.35 \%$ of students of the Faculty of Training Foreign Citizens. Symptoms of "borderline" conditions (8-10 points on a scale) were found in $54.48 \%$ and $31.6 \%$ of students of the medical faculty and students of the Faculty of Training Foreign Citizens, respectively. Clinically expressed anxiety and depression (11-21 points) were found in $27.09 \%$ of medical students and in $35.05 \%$ of foreign students.

In the gender distribution, among students of the medical faculty, the normal level of anxiety and depression during preparation for passing modular controls is more common among girls, accounting for $20.8 \%$, compared to $15.5 \%$ among males. It is worth noting that the symptoms of "borderline" conditions and the level of clinically pronounced anxiety and depression were higher among male students and amounted to $55.25 \%$ and $28.75 \%$, respectively. In a student current, "borderline" conditions are noted in $53.6 \%$ of cases, and clinically pronounced anxiety-depressive symptoms in $25.4 \%$.

As for the students of the Faculty of Training of Foreign Citizens, the picture of the sexual distribution is somewhat different, namely: the symptoms of "borderline" conditions were higher among girls $-44.0 \%$, while among men - 19.25\%. However, 
male students among foreign students had a high level of clinically pronounced anxiety and depression $-38.45 \%$, and among students it was slightly lower $-30.0 \%$.

The results of the clinical interview indicate depressive spectrum disorders among Ukrainian students of the medical faculty. Normal indicators, that is, the absence of depressive symptoms, were found in $76.4 \%$ of girls and in $76.9 \%$ of children. Signs of moderate depression were found in $9.02 \%$ of female students and in $1.2 \%$ of male students. Progressive depression in both sexes was manifested at almost the same level: $14.5 \%$ in women and $15.3 \%$ in men. It is worth noting that the symptoms of severe depression or a major depressive episode were observed in males and amounted on $6.6 \%$ of cases, among women this figure was only $0.08 \%$.

After processing the data from a survey of students of the Faculty of Training Foreign Citizens, we received the following indicators: $64.0 \%$ of students and $46.18 \%$ of male students did not have depressive symptoms; We found signs of moderate depression in $24.2 \%$ of girls and in $45.08 \%$ of boys; progressive depression - $11.8 \%$ among women and $8.74 \%$ among men. It should be noted that the symptoms of severe depression or a major depressive episode among students of the students of the Faculty of Training Foreign Citizens were not observed.

Conclusions: Thus, the study confirmed that the exam, as a stressful moment of the external identity test, caused the emergence of protective mechanisms in medical students in the form of emotional and behavioral changes and disorders. The results obtained indicate the presence of adaptation disorders during the period of the altered psychoemotional status in all the studied groups.

\section{References:}

Castaldelli-Maia J.M.,Martins S.S., Bhugra D. et.al.(2012) Does Ragging Play a Role in Medical Student Depression - Cause or Effect? Journal of Affective Disorders, 139 (3), 291-297.

Dyrbye, L.N., Harper, W., Durning, S.J. et.al. (2011) Patterns of distress in US medical students Medical Teacher, 33 (10), 834-839.

Alexandrino-Silva C., Pereira, M.L., Bustamante, C. et. al. (2009) Suicidal ideation among students enrolled inhealthcare training programs: a cross-sectional study. Revista Brasileira de Psiquiatria, 31 (4),338-344.

Baldassin S. Silva N., Correa de Toledo T. Ferraz Alves et.al. (2012) Depression in medical students: Cluster symptoms and management. Journal of Affective Disorders, 50(1).

Zigmond A.S., Snaith RP. (2012) The hospital anxiety and depression scale. Acta Psychiatr Scand, 67(6), 361-70.

Svanborg P. A., Asberg M. (2001) A comparison between the Beck Depression Inventory (BDI) and the self-rated version of the Montgomery-Asberg Depression Rating Scale (MADRS). J Affect Dis., 64, 203-16

Key words: depression, anxiety, altered psychoemotional state 


\title{
NEW METHODS FOR INSURING PSYCHIC HEALTH IN ADOLESCENTS IN THE RESIDENTIAL ENVIRONMENT
}

\author{
Alina Maria Breaz \\ Aurel VlaicU University from Arad, Romania
}

\begin{abstract}
:
Background: Adolescents from placement centers are more likely to develop disharmonious personality structures, due to the multiple risk factors existing in the residential environment: lack of an identification model, absence of attachment, conflicts with other colleagues or staff. That is why it is necessary to intervene in order to maintain the mental balance of adolescents and to create the necessary premises for a harmonious structuring of the personality.

Methods: Worked in the team (psychologist, social worker) for the implementation of an intervention program consisting of 12 sessions of cognitive behavioral psychotherapy and 12 sessions of care counseling, which were held once a week for 3 months. The adolescents included in the study were 40, divided into 4 groups of 10 each for psychotherapy and counseling sessions. At the beginning and at the end of the intervention, a personality questionnaire was applied (Woodworth-Mathews) to highlight the personality traits.

Results: Comparing the answers with the help of the t-Student test revealed significant differences between the personality trait averages in the two assessments, demonstrating that the intervention performed had favorable results in attenuating the marked features and in restoring the mental balance and the mental health of the adolescents.

Conclusions: The combined intervention programs (psychotherapy and counseling) can contribute to the improvement of the mental health of the adolescents in the placement centers and help to structure harmonious personalities of the adolescents in the residential environment.
\end{abstract}

Key words: adolescents, residential environment, psychotherapy, counseling, personality traits 


\title{
The role of sexual education in preschool mental health care
}

\author{
Oksana Los \\ Kherson State University, Kherson, Ukraine
}

The article is devoted to the problem of sexual education in preschool childhood, the author describes the psychological aspects of sexual development of a person in preschool age, discusses in detail the periods of formation of sexual identity, criteria of mental health, the importance of sexual education in the harmonious development of the personality of the child.

The development of new, more meaningful activities in the preschool childhood promotes the development of deeper and more stable emotions, connected not only with loved ones, but also with distant goals, not only with those objects that the child perceives, but also with those that he imagines. Activity generates, first and foremost, positive emotions, its purpose, the meaning it acquires for the child, and the very process of its fulfillment. Social emotions (likes, dislikes, preferences, etc.) are intensively developing. Intellectual emotions arise. In the process of communicating a child with adults, its moral feelings are formed. Manifestations of self-esteem are varied: both self-esteem and a sense of shame and unease develop. During the preschool childhood, the deepest layers of the psyche are laid and formed, which affect the further development of the individual.

Gender differentiation is most intimately woven into the canvas of this period. Children need to know their bodies to maintain their health. At preschool age, they are interested in their own bodies. Interest in one's own body is evident from birth. With age, the child freely distinguishes and correctly names the organs and parts of his body: eyes, tongue, lips, teeth, ears, hair; head, neck; torso - back, abdomen; hands and feet with fingers.

Interested in acting on their own experience. Even before the age of three, the child makes a "discovery" - shows where her eyes, ears, mouth, nose, tongue, teeth. He calls his actions: "I see," "I hear," "I said," etc. Parents and caregivers should remember that satisfying a child's interest in their own body is a major need. It is known that the unmet needs of the child cause suffering, and frequent suffering leads to the emergence of "destructive" emotions of anger, anger, aggression. They destroy the child itself (and the psyche, health in general), and its relationship with the environment. And from the experience gained during the preschool years, the child depends to a great extent on the optimist or pessimist, how much he or she will believe in his / her powers, and therefore how he / she will be able to overcome ordinary difficulties of life, resist obstacles, temptations, etc.

Key words: preschool child, emotional-volitional sphere, sexual development, age-related periodization of mental development, mental health criteria.

\section{Література:}


Исаев Д.Н., Каган В.Е. Половое воспитание детей: Медико-психологические аспекты. Изд. 2-е, перераб. и доп. Ленинград: Медицина, 1988. 360 с.

Калуга В.Ф. Приречена сексуальністю. Проблема ідентичності людини з огляду на iï сексуальну природу. Ніжин: Видавець ПП Лисенко М.М., 2011. 488 с.

Лохвіцька Л.В. Програма 3 основ здоров'я та безпеки життєдіяльності дітей дошкільного віку «Про себе треба знати, про себе треба дбати». Тернопіль : Мандрівець, 2014. 120 с.

Психологічне здоров'я дошкільників. Уклад. Т.I. Прищепа. Харків: Вид. група «Основа», 2010. 239c.

Родомицька Н., Романюк О., Сова Л. Гендерне виховання в ДНЗ. Київ: «Вид.група «Шкільний світ», 2018. 144 с.

Ткалич М. Г. Гендерна психологія: Навч. посіб. Київ: Академвидав, 2001.

(C) NDSAN (MFC - coordinator of the NDSAN), Italy, 2019 


\section{Group psychological phenomena and mental health preservation in complex social situations Групові психологічні феномени і збереження ментального здоров'я у складних соціальних ситуаціях \\ Olga Korobanova \\ Ольга Коробанова \\ Інститут соціальної та політичної психології НАПН України, Київ, Україна}

Політичні та економічні реалії чинять безумовний вплив на життя людей. В сучасній Україні за умов гібридної війни, анексії Криму та воєнної агресії на сході України постає проблема соціально-психологічних факторів збереження ментального здоров'я. У складні соціальні ситуації потрапили різні верстви населення України, серед них внутрішньо переміщені особи, а також пересічні громадяни різного віку. Оскільки всебічний аналіз та оцінка ситуації іiі учасниками, які знаходиться в цій ситуації та переживають іï, утруднена, можливі часткові, подекуди помилкові висновки, якими вони будуть керуватися при виборі певної лінії поведінки.

Соціальні ситуації як такі представляють фрагмент соціального життя, який визначається залученими людьми, характером їх взаємин, місцем дії, змістом діяльності (Основи соціальної психології, 2008). Ситуація також є сукупністю подій, соціальних умов і обставин, у яких опинилися ії учасники та має визначні особливості, які слід враховувати при iї аналізі.

Складну соціальну ситуацію характеризують неспроможність окремої людини або групи людей подолати цю ситуацією самотужки; масштаб та сила впливу на учасників взаємодії; виникнення екстремальних умов, міжособових та соціальних конфліктів, ситуації ризику. Вимірами ситуації, що ускладнюють iї, можуть стати ступінь небезпеки, конфліктності, ворожості оточення. Можливі відчуття «напруженого очікування», незручностей, надмірних фізичних навантажень.

Складність визначає «ситуація неможливості», у якій суб'єкт відчуває неможливість реалізації власних інтенцій та яка описується як стрес, фрустрація, конфлікт та криза (Василюк, 1984). Також до цих видів складних ситуацій слід додати травму як найбільш важку, складну в переживанні людиною ситуацію. Зазначимо, групова динаміка може утворювати континуум від групової напруженості до групової травми.

Складовими емпіричної моделі виникнення групової феноменології вважаємо спрямовані на складну ситуацію когнітивно-перцептивні процеси, визначення та порівняння статусів своєї та «іншої» групи, , порушення рольового балансу, редукція рольового репертуару учасників на тлі включеності у групу, утворення соціальних ілюзій. Неможливість подолати складну ситуацію може травмувати іiі учасників або викликати, зокрема, явища неточної, «помилкової» перцепції складної соціальної ситуації або іiї інтерпретації, та спричиняти виникнення соціальних ілюзій як прояв уходу від нестерпної реальності внаслідок травми.

Зауважимо, що ми відносимо до соціальних ілюзій продукти 
сприймання членами групи соціально-психологічних ситуацій, в умовах яких відбувається групова взаємодія. Ілюзія - викривлене психічне відображення об’єктивної реальності (Платонов, 1984). Вважаємо соціальні ілюзії продуктами колективного сприймання, у яких неповно або неточно відображується групова реальність: соціальна ситуація взаємодії, групові цілі та цінності, учасники взаємодії. Таким чином, соціальні ілюзії $є$ проявом групового несвідомого, про що може свідчити існування певного протиріччя.

Зокрема, проведене нами дослідження цінностей за методикою М. Рокича, у якому прийняли участь 75 студентів київських вузів віком від 18 до 25 років свідчить про те, що найвищі ранги серед термінальних цінностей зайняли здоров'я (фізичне і психічне) (1), кохання (духовна та фізична близькість 3 коханою людиною) (2), щасливе сімейне життя (3), свобода (самостійність,незалежність в судженнях і вчинках) $(4,5)$, активне діяльне життя (повнота та емоційна насиченість життя) $(4,5)$, розвиток (робота над собою, постійне фізичне та духовне удосконалення) (6), життєва мудрість (зрілість суджень та здоровий глузд, який досягається життєвим досвідом) (7,5), матеріально забезпечене життя (відсутність матеріальних труднощів) (7,5), пізнання (9), краса природи та мистецтва (переживання прекрасного) (10). У дужках наведений груповий ранг тієї чи іншої цінності.

Останні позиції зайняли щастя інших (добробут, розвиток та удосконалення інших людей, всього народу, людства в цілому) (16), суспільне визнання (повага оточуючих, колективу, товаришів по роботі) (17), продуктивне життя (максимально повне використання своїх можливостей, сил та здібностей) (18).

Найвищі ранги серед інструментальних цінностей у проведеному дослідженні зайняли вихованість (1), терпимість (2), життєрадісність (почуття гумору) (3), освіченість (широта знань, висока загальна культура) (4), чесність (правдивість та щирість) $(5,5)$, відповідальність (почуття обов'язку, вміння тримати слово) $(5,5)$, широта поглядів (вміння розуміти чужу точку зору, поважати інші смаки, звичаї, звички) (7), тверда воля (вміння настояти на своєму, не відступати перед труднощами) (8), раціоналізм (вміння реально та логічно мислити, приймати обдумані, раціональні рішення) (9), чуйність (10). На останні позиції вийшли дисциплінованість (16), незалежність (17), непримиримість до недоліків в собі та інших (18).

Зазначимо, що цінності вихованості, терпимості, життєрадісності та освіченості змальовують портрет позитивної вихованої молодої людини, приємної у спілкуванні, слухняної та толерантної. Проте, як показники переконань молодих людей в тому, що певний образ дій або властивість особистості є переважними в будь-якій ситуації, вони справляють враження неможливості за їх рахунок досягти цінностей-цілей, оскільки не приведуть ані до здоров'я, ані до щасливого сімейного життя, ані до свободи, не допоможуть зберегти кохання.

В груповому полі соціальної взаємодії багато неусвідомленого. Відсутні причинно-наслідкові зв'язки та узгодженість між переважними груповими цінностями-цілями та цінностями - засобами їх досягнення Так, сміливість у відстоюванні своєї думки (посідає ранг 14,5) і незалежність (займає ранг 17) серед інструментальних цінностей, в той час, як у 
термінальних цінностях свобода (самостійність, незалежність в судженнях і вчинках) посідає високий ранг $(4,5)$.

У той же час, цінності щастя інших (добробуту, розвитку та удосконалення інших людей, всього народу, людства в цілому) (ранг 16), суспільного визнання (отримання поваги оточуючих, колективу, товаришів по роботі) (ранг 17), а також продуктивного життя (як максимально повного використання своїх можливостей, сил та здібностей) (ранг 18) посідають останні місця серед термінальних цінностей в молодих людей, які прийняли участь у досліджуванні.

На основі отриманих результатів, можна говорити про сформованість у молоді системи цінностей, наявність яких в учасників соціальної взаємодії сприятиме взаєморозумінню та полегшить виконання спільних дій. Разом 3 тим, можна вважати, що пріоритетні цінності-засоби не ведуть до досягнення цінностей-цілей, що можна, на нашу думку, вважати проявом однієї з соціальних ілюзій.

Людська властивість видавати бажане за дійсне та перетворювати прагнення і бажання на мотиви реальних дій може лежати в основі виникнення соціальних ілюзій. Так, наші дослідження показали, що у сприйманні іншого члена групи, якому учасник симпатизує, він ідентифікується 3 ним та сприймає приємного іншого подібним собі. Схожість між рисами «Я» і рисами «симпатичного іншого» простежується у кореляційному зв'язку між ними і $є$ значущою на рівні 0,01 (Свідоме і несвідоме у груповій взаємодії, 2018). Превалювання настановлення приписувати симпатичному одногрупникові риси образу «Я», схожі на власні, певним чином, також можна вважати проявом соціальної ілюзії.

Соціальні ілюзії і іх зв'язок з груповими феноменами вимагають докладного подальшого дослідження. На даному етапі поки що неможливо дати відповідь, чи є виникнення соціальних ілюзій захисним механізмом, втечею від реальності (у мрії, бажання) у складних ситуаціях або лише проявом функціювання групового несвідомого, якому властиві свої особливості.

Ключовими показниками вияву групових психологічних феноменів є: порівняльні статуси своєї і «чужої» групи, підміна реальності соціальніими ілюзіями, рольові преференції членів групи на тлі включеності у групу, а також мотивація соціальної поведінки. Порівнюючи статус своєї і іншої групи, член групи може надати переваги власній групі, а може піддатися ефекту ореола, коли інша група (наприклад, група студентів старшого курсу) набуває вищий статус порівняно 3 власною групою приналежності. Таким чином, члени групи можуть наділяти високим або низьким статусом свою групу у порявнянні з іншою.

Рольові преференції після пережитих складних ситуацій набувають змін (зокрема, за нашими даними, після подій Майдану підвищилася оцінка психологічних ролей «спостерігача», «новатора», «політпротестуючого»або «абсентеїста» (перераховані у порядку зниження значущості). Включеність можна охарактеризувати як особливий соціально-психологічний механізм актуалізації суб'єктних властивостей членів групи і утворення групи як цілісного об'єднання. Включеність у групову взаємодію визначимо як входження людини у систему вимог, норм, ролей, прав, обов'язків і очікувань, які пред'являють до нього група. Разом 3 тим у групових 
процесах слід мати на увазі як існування громадської (колективної) думки, так і існування групового несвідомого, що точить непрогнозований вплив на групову поведінку. Групові феномени виникають на тлі прояву несвідомих тенденцій у поведінці (зниженні або розсіянні уваги, втомі, сильних емоціях, потребі швидко реагувати на загрозу, підвищеній важкості завдань та т. ін.).

Як наслідок анексії Криму і військових дій на Донбасі частина населення покинула свої будинки на постійному місці проживання i оселилася на нових місцях. Внутрішньо переміщені особи, безумовно, знаходяться в епіцентрі складної соціальної ситуації, триває процес адаптації. Втім, таким було їх рішення щодо зміни складної ситуації на краще, коли вони зорієнтувалися в ній.

Зокрема, проведені нами глибинні інтерв'ю $з$ колишніми мешканцями міст Луганська та Донецька допомогли виявити, що ситуації, об'єктивно наділені складнощами і ознаками певної неможливості, разом з тим, можуть не сприйматися учасниками, які наділені достатніми інтелектуальними та емоційними ресурсами, а також мають групову підтримку, як складні. Так, вони відчували напруження i стресові переживання, що допомогло активізувати їх адаптаційні можливості. Відтак, вважаємо, що розроблення засобів психологічної допомоги соціальним суб'єктам, що переживають труднощі групової взаємодії у складних соціальних ситуаціях, має лежати, в тому числі, у площині підвищення їхніх особистих ресурсів і підтримк 3 боку принаймні однієї референтної нрупи.

Співробітниками лабораторії психології малих груп і міжгрупових відносин було здійснене теоретичне обгрунтування процесів породження групових феноменів, спричинених складними соціальними ситуаціями (Chorna, Gornostai, Tsyhanenko, Pletka, Korobanova, Vus, 2018). Під час групової взаємодії в складних соціальних ситуаціях виникають переживання членів групи, які можуть знаходити вияв у груповій напруженості, груповій диференціації, рольових преференціях, появі мікрогруп, як складових групової динаміки. Виникнення групових феноменів, таких як внутрішньогруповоий фаворитизм, міжгрупова дискримінація, соціальна фасилітація, конформізм, групове мислення та iн. на певний час послаблюють це відчуття напруженості, знижують конфліктність.

Групові психологічні феномени несуть певну захисну функцію, i виникають не завжди, а за певних умов. Зокрема, міжгрупова дискримінація може виникати у відповідь на агресивні впливи. Внутрішньогруповий фаворитизм вимагає для появи певного ціннісного аксіологічного підгрунтя і проявляється поряд з груповою підтримкою. При цьому вплив складної ситуації на групову феноменологію залежить від iї смислової інтерпретації учасниками та приводить до проявів групової динаміки, як от змін у розмірі інгруп та діапазоні рольового репертуару їх учасників. Групові феномени виникають як відображення групової динаміки; на момент виникнення та функціювання групові феномени знижують групову напруженість. Групові феномени виникають на тлі прояву несвідомих тенденцій у поведінці (зниженні або розсіянні уваги, втомі, сильних емоціях, потребі швидко реагувати на загрозу, підвищеній важкості завдань та т. ін.).

Групові феномени підсилюються, коли занурені у непросту ситуацію члени групи не здатні всебічно проаналізувати ситуацію, змоделювати подальші дії, спрямовані на подолання складності ситуації, а також 
відрефлексувати рольові паттерни поведінки у змінюваній ситуації. Підвищується включеність до інгруп, пов'язана 3 прагненням отримати групову підтримку, отримати підтвердження типовості своїх поведінкових та емоціональних реакцій на складну ситуацію та їхню відповідність реакціям інших членів групи. В умовах складних соціальних ситуацій та під ïх безпосереднім впливом відбувається динаміка процесів групової інтеграції та диференціації, а саме, зменшення або збільшення мікрогруп, редукція рольового репертуару учасників.

Низка інгрупових та аутгрупових феноменів є реакцією людей на присутність інших, а також $\epsilon$ механізмами функціонування груп, посередством яких здійснюються групові процеси і досягаються групові стани, які забезпечують інтеграцію індивідуальних дій у спільній груповій діяльності i спілкуванні. Серед них міжгрупова дискримінація, внутрішньогруповий фаворитизм, соціальна фасилітація, конформізм, групове мислення, групова поляризація та ін.

Групова ідентичність, в основі якої є розподіл на «Ми» і «Вони», має на крайньому полюсі міжгрупову дискримінацію, яка передбачає міжгрупові конфлікти (дослідження М. Шеріфа), міжгрупову ворожість, агресію, негативні аутгрупові стереотипи. При цьому найпоширенішими серед імпліцитних моделей консолідації $\epsilon$ «протестні» моделі гуртування в боротьбі проти спільного ворога, зовнішньої загрози і т. ін. (Петрунько, 2014)

Метою міжгрупової дискримінації може бути встановлення відмінності між групами на користь власної (Г. Теджфел). Проте дослідження (Кондратьев, Емельянова, 2011) свідчить про диференційований прояв даного феномену в студентському середовищі та його статусно-референтний характер.

Внутрішньогруповий фаворитизм (солідарність) може бути обумовлений реальною загрозою, більш повним усвідомленням власної групової ідентичності та непроникністю групових меж, (Уайт, Самнер, Шеріф, Козер), ситуаціями конкуренції та протистояння між групами. Сутність внутрішньогрупового фаворитизму у підсиленні згуртованості i підтримки всередині групи. За нашими даними, груповий фаворитизм означується спільними цінностями, що сповідує група, спільними аксіологічними засадами, загальнолюдськими принципами, як от справедливості, рівних прав. О. Ю. Дроздов (2014), порівнюючи образи України i Росії в геополітичній свідомості студентів, встановив, що військовий конфлікт істотно погіршив образ Росії, натомість образ України поліпшився лише частково, таким чином, механізм міжгрупової дискримінації в масовій геополітичній свідомості діє сильніше, ніж внутрішньогруповий фаворитизм

У складних ситуаціях, коли учасники відчувають власну некомпетентність, недостатню інформованість, розгубленість або невпевненість, підвищується їхній конформізм, як схильність прислуховуватися до думки групи у збиток власній думці під впливом групового тиску (С. Аш). Деякі автори підкреслюють значення у прояві людиною конформізму відсутності власної думки у певних ситуаціях (Озерова, 2017). Схильність відреагувати на дії іншого аналогічною поведінкою, розглядається деякими психологами як взаємність (Д. Бургун). 
Зазначимо, що на прояв конформізму людиною впливає високий статус інших членів групи та характер ситуації, яку вона переживає. Невизначеність ситуації, неясність та багатозначність інформації сприяють орієнтації людини на думки інших людей. Наші дані свідчать, що деякі особи, які нещодавно покинули непідконтрольну Україні територію, багаторазово змінюють судження про українців, нацгвардійців, мешканців Донбасу, на полярні, протилежні за змістом, ніби у пошуках слушної думки, яку схвалює та група, у якій вони наразі присутні.

Також у дослідженнях груп внутрішньо переміщених осіб виявлено, що учасників цих груп легко «звернути 3 шляху істини», вони легко змінюють власну думку та слухняно приймають запропонований напрямок дій та оцінок, прагнуть не виділятися серед інших.

Групове мислення (схильність членів групи погоджуватися 3 більшістю або лідером групи, та на основі цього приймати важливі рішення) виникає в ситуації, коли пошук згоди переважає над реалістичною оцінкою можливих дій (I. Джейніс, 1972). При цьому висока ступінь залученості до системи групових уявлень та цінностей може заважати прийняттю правильного рішення. Зокрема, групове мислення знаходить прояв в оцінці подій на сході учасниками: $є$ свідчення, що ті, що залишилися у зоні відчуження, знаходять аргументи, виправдовуючі їхнє рішення.

Серед наративів учасників подій на сході зустрічаємо описи «стокгольмського синдрому» як ідентифікації з тими, хто чинить насилля та прагнення виправдовувати їх.

У складних соціальних ситуаціях групи людей потрапляють в поле дії сил, що спричинюють феномени міжгрупової дискримінації, внутрішньогрупового фаворитизму, конформізму, групового мислення, оціальної фасилітації та ін.

Література.

Василюк Ф.Е. Психология переживания. Анализ преодоления критических ситуаций. М.: Изд-во МГУ, 1984. - 200 с.

Дроздов О. Ю. Динаміка геополітичних уявлень молоді на тлі російськоукраїнського конфлікту 2014 року / О. Ю. Дроздов // Проблеми політичної психології: зб. наук. праць. - К.: Міленіум, 2014. - Вип. 1 (15). - C. 258-266.

Кондратьев М.Ю. Социально-психологические особенности взаимосвязи самооценки и личностно-ролевой взаимопредставленности студентов / М.Ю. Кондратьев, Е.В. Емельянова// Социальная психология и общество. - 2011. - №1. - С. 56 - 73.

Основи соціальної психології: Навчальний посібник / О.А.Донченко, М.М.Слюсаревський, В.О.Татенко, Т.М.Титаренко, Н.В.Хазратова та ін.; За ред. М.М.Слюсаревського. - К.: Міленіум, 2008. - 496 с.

Петрунько О. В. Імпліцитні моделі консолідації громадської думки у свідомості студентської молоді / О. В. Петрунько // Проблеми політичної психології: зб. наук. праць. - К.: Міленіум, 2014. - Вип. 1 (15). - C. 75-86.

Свідоме і несвідоме у груповій взаємодії: монографія / [П.П.Горностай, О.Л.Коробанова, О.Т.Плетка, Г.В.Циганенко, Л.Г.Чорна]; за наук.ред. П.П.Горностая. - Кропивницький, Імекс-ЛТД, 2018. - 244 c. 
Gornostai P., Chorna L., Vus V., Tsyhanenko H., Pletka O., Korobanova O. (2018)/ Mental Health: Dislocation of the Concept in the Small Group / Mental Health: Global Challenges of XXI century/ MNCG Journal. Pp/ 18 - 20. Rome. Retrived from: http://www.mhcgj.org/mental-healthdislocation-of-the-concept-in-the-small-group/ [in English].

(C) NDSAN (MFC - coordinator of the NDSAN), Italy, 2019 


\title{
MONITORING OF HUMAN RIGHTS IN THE AREA OF MENTAL HEALTH: EUROPEAN AND NATIONAL DIMENSIONS \\ МОНІТОРИНГ ПРАВ ЛЮДИНИ У СФЕРІ ПСИХІЧНОГО ЗДОРОВЯ:СВРОПЕЙСЬКИЙ ТА НАЦІОНАЛЬНИЙ ВИМІР
}

\author{
Yulia Paskevska \\ Zaporizhzhia National University, Zaporizhzhia, Ukraine
}

\begin{abstract}
In the article the necessity of compliance of the Ukrainian legislation to the European standards of observance and protection of human rights in the field of mental health was noted, and the human rights monitoring tools were provided.
\end{abstract}

Keywords: human rights, mental health, monitoring, quality of service.

У статті зауважено на необхідності відповідності українського законодавства європейським стандартам дотримання та захисту прав людини у сфері психічного здоров'я, надано інструментарій моніторингу прав людини.

Ключові слова: права людини, психічне здоров'я, моніторинг, якість надання послуги.

Вступ. Реформування системи охорони здоров'я - це багатогранний процес, до якого мають бути залучені Міністерство охорони здоров'я України як лідер процесу, а також інші інституції. I лише співпраця та координація всіх зацікавлених сторін можуть сприяти тому, щоб в Україні відбулися якісні реформи.

На сьогодні для українського суспільства важливим $\epsilon$ імплементація Концепції розвитку охорони психічного здоров'я в Україні на період 2030 року. Створення цілісної, ефективної системи охорони психічного здоров'я, яка заснована на принципах доступності, повноти та комплексності, міждисциплінарного підходу, координації та безперервності послуг, рівності та поваги до прав і свобод людини , і яка забезпечує покращення якості життя людини.

За визначенням Всесвітньої організації охорони здоров'я (ВОО3), психічне здоров'я - це стан благополуччя, при якому кожна людина може реалізувати свій власний потенціал, впоратися із життєвими стресами, продуктивно та плідно працювати, а також робити внесок у життя своєї спільноти [3].

Основними компонентами проблеми у сфері охорони психічного здоров’я в Україні є: 
$>$ слабка обізнаність щодо психічного здоров'я у суспільстві, що призводить до стигматизації та несвоєчасного звернення по професійну допомогу;

недосконалість національного законодавства у сфері психічного здоров'я та порушення прав людей з проблемами психічного здоров'я;

$>\quad$ відсутність системи профілактики психічних розладів, що базується на фактичних даних, та ефективної популяризації психічного здоров'я;

$>\quad$ недосконалість регулювання діяльності у сфері охорони психічного здоров'я;

$>$ низький рівень кадрового забезпечення психологами, психотерапевтами, соціальними працівниками та іншим персоналом, який залучається до надання допомоги у сфері психічного здоров'я, недостатність системи формування та підтримки професійних компетентностей серед фахівців у сфері психічного здоров'я та інших суміжних професій;

відсутність системного впровадження галузевих та міжгалузевих стандартів у сфері охорони психічного здоров'я та контролю якості допомоги у зазначеній сфері;

надмірна зосередженість допомоги у сфері психічного здоров'я у спеціалізованих закладах охорони здоров'я та інтернатних закладах системи соціального захисту; низька доступність психологічної та психотерапевтичної допомоги; дефіцит служб, які б базувалися на рівні територіальних громад, реабілітаційних і соціальних послуг; відсутність систем підтриманого працевлаштування та зайнятості, підтриманого проживання; відсутність ефективної системи підтримки сімей осіб, що доглядають за особами з психічними захворюваннями, а також недостатній розвиток кризової психологічної допомоги та програм раннього втручання на рівні територіальних громад;

$>$ обмежене використання сучасних технологій, методів та процедур оцінки у сфері психічного здоров'я та надання допомоги особам 3 проблемами психічного здоров'я під час надання первинної медичної допомоги;

$>\quad$ недостатня диференційованість надання допомоги у сфері охорони психічного здоров'я 3 урахуванням чутливості до потреб різних груп суспільства та обмежена участь i залучення осіб 3 психічними та інтелектуальними порушеннями та членів їх сімей до планування допомоги, iї реалізації та оцінки;

$>$ відсутність ефективного адміністрування та моніторингу у сфері охорони психічного здоров'я, недостатня координація між різними державними органами у наданні допомоги особам з проблемами психічного здоров'я [3].

Мета. У цьому контексті актуальною метою нашої статті постає висвітлення саме проблеми дотримання міжнародних стандартів забезпечення та захисту прав людини, приведення національного законодавства у відповідність до міжнародних правових актів, а також імплементація дієвого інструментарію з моніторингу прав людини у сфері психічного здоров'я.

Основний зміст. Захист прав психічно хворих осіб, побудова діяльного механізму щодо дійсної реалізації прав цієї найбільш незахищеної 
категорії українських громадян $є$ завданням не тільки правовим, але й ціннісним і соціально-психологічним. Для України особливо гостро стоїть питання не нормативно - правової бази в питанні дотримання та захисту прав особи, що страждає психічними розладами, а в забезпеченні дієвого механізму дотримання та захисту прав людини, що має психіатричний діагноз відповідно до міжнародних стандартів.

За підрахунками Всесвітньої організації охорони здоров'я, кожна четверта людина у світі зіткнеться 3 психічним розладом впродовж життя. Дослідження Міжнародного медичного корпусу показують, що в Україні до 75\% людей з поширеними психічними розладами не мають доступу до допомоги. Це відбувається через сором, страх, відсутність довіри до системи охорони здоров'я, брак інформації та обізнаності, високу вартість лікування, велику географічну відстань. Саме тому зробити систему охорони психічного здоров'я доступною для українців - першочергове завдання, забезпечуючи в такий спосіб реалізації їх прав.

Зазначене зумовлює високий рівень інституціалізації і відповідно сегрегації та стигматизації осіб, що мають психічні розлади. До осіб 3 психічними та інтелектуальними порушеннями, які перебувають у конфлікті із законом, переважно застосовується система покарання, а не реабілітації та ресоціалізації. Недостатня увага приділяється профілактиці, психосоціальним методам, організації охорони психічного здоров 'я на рівні первинної медичної допомоги, наданні психотерапевтичної допомоги, реабілітаційним заходам, а також службам охорони психічного здоров'я, які функціонують у територіальних громадах, недостатньо розвинуті амбулаторне раннє втручання на рівні територіальних громад та практика домашнього супроводу.

Відповідно до Закону України «Про психіатричну допомогу» [1], правові і організаційні принципи забезпечення громадян психіатричною допомогою, виходячи 3 пріоритету прав і свобод людини і громадянина, встановлює обов'язки органів виконавчої влади і органів місцевої самоврядності по організації надання психіатричної допомоги і правового і соціального захисту осіб, які страждають на психічні розлади, регламентує права і обов'язки фахівців, інших працівників, які беруть участь у наданні психіатричної допомоги.

В рамках реалізації проекту WHO Regional Office for Europe project on «WHO Project on adults with mental disabilities living in institutions in the European region: Phase 3 - From Quality Assessment to Quality Improvement» нами було здійснено моніторинг прав людини у сфері психічного здоров'я та проведено курс тренінгового навчання у Чернівецькій обласній клінічній психіатричній лікарні та Жмеринському психоневрологічному інтернаті у період грудень 2018-жовтень 2019 роки.

Моніторинг прав людини у сфері психічного здоров'я відбувався відповідно до набору інструментів та правил Всесвітньої організації охорони здоров'я:

Стандарт 1. Право на достатній життєвий рівень (стаття 28 Організації Об'єднаних Націй Конвенція про права інвалідів (КПІ)

Стандарт 2. Право на досягнення стандарту найвищого рівня фізичного і психічного здоров'я (стаття 25 Конвенції про права інвалідів) 
Стандарт 3. Право на юридичну підтримку, особисту свободу та недоторканність (статті 12 і 14 Конвенції про права інвалідів)

Стандарт 4. Свобода від катувань та жорстокого, нелюдського або принижуючого гідність поводження чи покарання та експлуатації, насильства та жорстокого поводження (статті 15 і 16 КПІ)

Стандарт 5. Право на незалежне життя та співробітництво в суспільстві (стаття 19 з КПІ) [2].

Практична значущість. 3 огляду на отримані результати оцінки якості установ, які надають довгострокову допомогу дорослим 3 психосоціальною та інтелектуальною недостатністю, найважливішим вбачається подальше створення потенціалу впровадження доступних інструментів 3 розробки та налагодження системи управління якістю QualityRights та імплементацію таких компонентів:

1. Розвиток потенціалу у нових інструментах навчання та нагляду WHO QualityRights

2. Впровадження стандартів якості на об'єктах

3. Оцінка процесу та вплив поліпшення якості

4. Стратегічне повідомлення механізмів підвищення якості на місцевому, національному та регіональному рівнях

Висновок. Вбачаємо за необхідне у подальшому посилення потенціалу керівників спрямовувати реформи у сфері охорони психічного здоров'я, розробляти i втілювати науково обгрунтовану політику, покращувати міжсекторальну співпрацю, розбудовувати соціальнопсихологічний супровід. Впевнені, що спільні зусилля щодо розвитку охорони психічного здоров'я в Україні сприятимуть здійсненню ефективної політики, а результати і рекомендації безумовно будуть впроваджуватися для удосконалення та поглиблення подальшої роботи у сфері покращення якості надання послуг щодо психічного здоров’я.

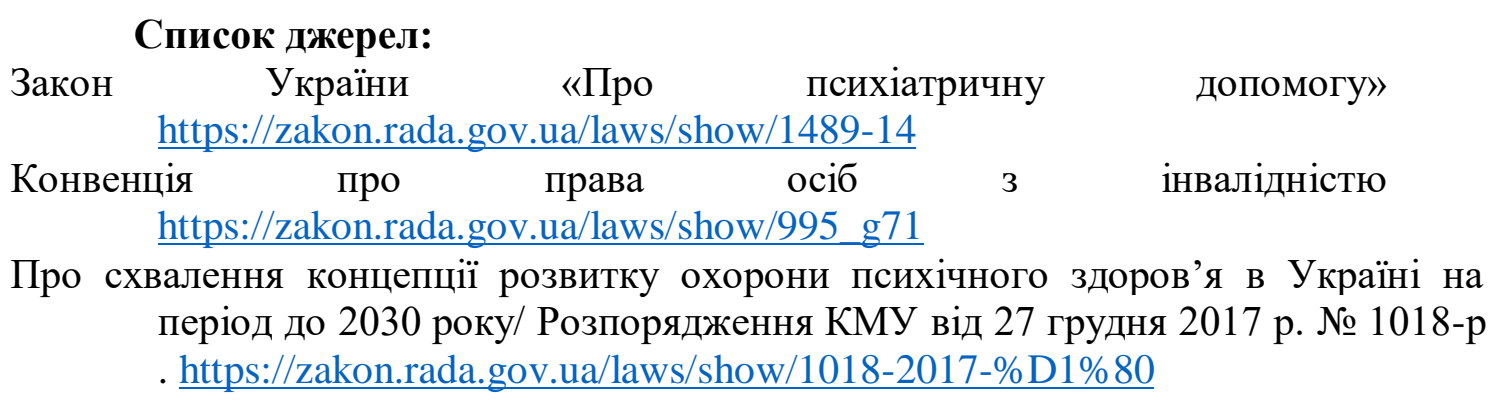

(c) NDSAN (MFC - coordinator of the NDSAN), Italy, 2019 


\title{
System supervision tasks for practicing psychologists at the initial stage
}

\section{of professional activity.}

\author{
Larysa Spitsyna \\ Zaporizhzhia National University, Zaporizhzhia, Ukraine
}

Introduction: Current trends in the development of a specialist in the field of psychology reflect the growing requirements for specialists in psychological care, and accelerated the awareness of the need to be accompanied by appropriate supervision.

Purpose: studying the opportunities and tasks of system supervision for practicing psychologists in the initial stage of professional activity.

Design/Methodology/Approach: The main part of our supervisory practice is an integrative approach implemented in the practice of intersubject interaction between the supervisor and supervisor (individuals, groups, teams, organizations).

Results. In our research, we proceed from the assumption that supervision is a form of professional counseling aimed at improving the quality of communications and cooperation in the professional context, a form of professional support in the field of helping occupations, in business, in psychological and psychotherapeutic practice, etc.

In the European model of supervision, carried out on the basis of the professional standards of the Association of national Organisation for Supervision in Europe (ANSE), in the process of group work supervisor with supervisor (group, organization) creates conditions for:

- Improvement of professional activity, first of all, due to improvement of interpersonal communication and interaction in groups;

- Solving problem, conflict situations depending on the current needs of the organization; Search for the best solution for the organization at the moment;

- Prevention of emotional burnout of employees of the organization;

- Creation of conditions for constructive communication, which involves working out and solving problems of members of the supervisory group, search and awareness of resources;

- Implementation of emotional support, achievement of understanding, allowing the client to realize the possibilities of self-help, creation of conditions for making an informed, well -balanced decision;

- Development of professional and socio-psychological competencies of employees of organizations.

Limitations and strengths of the study: Our model of supervision allows us to "include" the multi-level attention of the supervisor and, if necessary, to switch it to different aspects of his interaction with the supervisor, the content of his problem, the process and context of their interaction, the reflection of the case, which is very relevant at the initial stage of psychological practice.

Practical/Social value: This approach allows to improve the quality of professional activity, above all, by improving interpersonal communication and group interaction; 
Originality/Conclusions: We identified opportunities to use supervisory engagement resources to address a variety of professional challenges related to the professional development of a practicing psychologist.

Keywords: supervision, psychosocial support, practicing psychologist, professional experience, helping professions, professional activity.

\section{References:}

Howkins P., Shohet R. (2002) Supervision. Individual, group and organizational approaches. Ховкинс П., Шохет P. Spb (2002) Супервизия. Индивидуальный, групповой и организационный подходы. Спб.: Речь

Wiliyams Е. (2001) Уильямс Э. You are a supervisor. Six-focus model, roles and techniques in supervision. М. (2001) Вы - супервизор. Шестифокусная модель, роли и техники в супервизии. М.: Независимая фирма «Класс».

Carey, T. A., Mullan, R. J. (2004) What is Socratic questioning? Psychotherapy: Theory, Research, Practice, Training, Vol 41(3), p. 217-226. 
PROFESSIONAL HEALTH CARE PROGRAM AS A BASIC PERSONAL DEVELOPMENT RESOURCE

\title{
КОМПЛЕКСНА ПРОГРАМА ЗБЕРЕЖЕННЯ ПРОФЕСІЙНОГО ЗДОРОВ'Я ЯК БАЗОВОГО РЕСУРСУ ОСОБИСТІСНОГО РОЗВИТКУ ПЕДАГОГА
}

\author{
Olena Kosyhina \\ Олена Косигіна
}

Житомирський обласний інститут післядипломної педагогічної освіти м. Житомир, Україна

Communal institution «Zhytomyr Regional Institute of Postgraduate Pedagogical Education»

Анотація: Особистість учителя, як представника професії типу «людина - людина», у результаті тривалого виконання ним трудових функцій неминуче зазнає психологічних змін, які можуть негативно впливати на професійну діяльність у цілому. У зв'язку 3 цим зумовлюється пошук ефективних способів і технологій, що забезпечують педагогу оптимальні можливості збереження власної особистості і здоров'я.

Ключові слова: професійна деформачія, педагог, профілактика, особистість.

Abstract. The personality of a teacher, as a representative of a profession of the type "man-man", as a result of the long-term performance of his labor functions, inevitably undergoes psychological changes that may adversely affect professional activity in general. In this connection, the search for effective methods and technologies that provide the teacher with optimal possibilities for preserving their own personality and health is determined.

Key words: professional deformation, teacher, prevention, personality. 


\section{Актуальність та постановка проблеми дослідження.}

Професійне здоров'я педагога є необхідною умовою його активної життєдіяльності, самореалізації, розвитку творчого потенціалу. Воно позначається і на здоров'ї всіх інших учасників процесу міжособистісної взаємодії, на результатах всієї освітньої діяльності. Нездоровий педагог не зможе позитивно впливати на підвищення мотивації студентів/слухачів до якісного навчання та підвищення кваліфікаційного рівня, забезпечити необхідний рівень уваги, особистісний підхід, ситуацію успіху. Він не зможе займатися і розвитком здоров'язбережувальної компетентності у студентів/слухачів. Отже, прояви синдрому професійного згорання, педагогічних криз, деформації особистості педагога, неблагополуччя у психологічному стані, психічному здоров'ї, хроніфікація патологічного процесу на соматичному рівні безпосередньо впливають i на створення позитивного психологічного клімату у процесі освітньої міжособистісної взаємодії. Тому проблема збереження i зміцнення здоров'я викладача повинна бути однією із пріоритетних у сфері його життєвих і фахових інтересів. Психопрофілактичні програми, спрямовані на попередження професійних деформацій, мають набути широкого використання у контексті діяльності психологічних служб закладів вищої освіти.

Дотримуючись принципів організації освітнього процесу у системі післядипломної освіти, ми розробили профілактичні заходи і практичні поради, що здатні мінімізувати професійне вигорання педагогів, які проходять курси підвищення кваліфікації, та психопрофілактичні програми для викладачів, що працюють із дорослими людьми (студентами/ слухачами). У 
програму роботи з педагогами включені інтерактивні методи діяльності, спрямовані на профілактику подолання професійного вигорання, i, перш за все, - заходи, спрямовані на зняття дії стресора, зняття робочої напруги, підвищення професійної мотивації:

•професійне кураторство (надання індивідуальної і групової методичної професійної допомоги з певного фаху);

•емоційна підтримка (індивідуальні консультації, складання плану особистісного розвитку, планування часу поза роботою, що включає заняття спортом, правильне харчування, відпочинок та розваги, хобі, стосунки з родичами та друзями);

•управління стресом/запобігання стресу (техніки релаксації, арт-терапевтичні заняття, тренінгові заняття, балінтовські групи, а також проведення виїзних семінарів та занять (за запитом), присвячених розвитку навичок управління часом, побудові позитивних стосунків у команді).

3 метою спрямованої профілактики емоційного виснаження педагогам рекомендовано:

•навчитися розраховувати й обдумано розподіляти своє навантаження;

• забезпечувати відпочинок перед початком роботи;

•планувати час за межами професійної діяльності;

•вчитися переключатися з одного виду діяльності на інший.

Спираючись на основні теоретичні підходи до вивчення синдрому вигорання, нами розроблені рекомендації із запобігання професійного стресу і профілактики професійного вигорання, які представляють собою сукупність превентивних заходів, орієнтованих на зниження вірогідності розвитку 
передумов і проявів професійного стресу та синдрому вигорання. Необхідно також скласти індивідуальну програму для підтримання кожним педагогом власного фізичного й психоемоційного стану у тонусі. Впровадження інтерактивної роботи із запобігання професійного стресу та профілактики професійного вигорання у системі післядипломної освіти сприятиме подальшому особистісному розвитку, який $\epsilon$ передумовою розвитку професійних компетентностей педагога.

Професійна деформація педагогічних працівників являє собою процес поступового формування негативних змін у сталій структурі діяльності й особистості, що позначається на продуктивності праці, якості взаємодії з іншими учасниками освітнього процесу [5], відчутті комфорту, стані суб'єктивної задоволеності власним життям, почутті психологічної безпеки в умовах співпраці всіх учасників освітньої взаємодії.

На думку Грановської Р. М., професійні деформації проявляються через стереотипні дії. Слід зазначити, що на початку професійної діяльності розвиток стереотипних дій корисний, тому що вони сприяють покращенню первинного адаптаційного періоду. Але 3 часом стереотипії починають гальмувати професійний розвиток педагога, так як набувають домінуючий характер у діяльності викладача. Сприйняття ситуацій стає спрощеним, виникає самоупевненість в непогрішності засвоєних педагогічних методів i власних можливостей, що призводить до звуження обсягу професійного мислення, експлуатації одноманітних поведінкових алгоритмів.

Здійснений нами теоретичний аналіз проблеми розвитку професійних деформацій у педагогів та їх специфіки в умовах 
вищої школи, результати експериментального дослідження надають можливість стверджувати, що запропоновані науковцями педагогічні умови, визначений інструментарій та комплексна програма профілактичної роботи можуть у подальшому бути використані у практичній роботі психологічної служби університетів, Центрів практичної психології Інститутів післядипломної освіти, у професійній діяльності викладачів вищої школи та системи післядипломної освіти.

Проблема попередження професійних деформацій привертала постійну увагу науковців і практиків: психологів, лікарів, філософів. У контексті нашого дослідження важливе значення мають положення та висновки вітчизняних і зарубіжних науковців щодо виявлення головних чинників, що сприяють розвитку професійних деформацій у педагогів (об’єктивних, суб'єктивних та об'єктивно- суб'єктивних).

Сучасні науковці Агапов В.С., Безносов В.Г., Борисова М. В., Желагіна Т. А., Кузьміна Н. В., Мітіна Л. М., Сінягіна Н. Ю. виділяють наступні типи професійної деформації особистості педагога:

а) загальнопедагогічні деформащуї (характеризуються типовими змінами особистості у всіх осіб, що займаються педагогічною діяльністю);

б) типологічні деформації (викликані злиттям особистісних особливостей 3 відповідними структурами функцій педагогічної діяльності у поведінкові комплекси);

в) специифічні деформації особистості педагога (обумовлені специфікою викладання навчальних дисциплін); 
г) індивідуальні деформаиії (визначаються змінами, що відбуваються з підструктурами особистості і зовні не пов'язані 3 процесом педагогічної діяльності; коли відбувається розвиток якостей, що не мають безпосереднього відношення до педагогічної професії).

До основних суб'єктивних ознак сприятливого для якісної міжособистісної взаємодії соціально-психологічного клімату у закладі освіти належать: можливість для членів колективу вільно висловлювати власні думки під час обговорення питань; відсутність тиску керівника на підлеглих і визнання за ними права приймати відповідальні для колективу рішення; достатня інформованість членів колективу про завдання та стан справ під час їхнього виконання; задоволеність належністю до колективу; прийняття на себе відповідальності за стан справ у колективі кожним його членом.

Як свідчить практика, реальне життя будь-якої організації це комплексне поєднання службових, організаційноуправлінських та міжособистісних стосунків. Члени педагогічного колективу, з притаманними їм психологічними особливостями, особистими пристрастями та інтересами, власною мотивацією впливають на якість та характер загального психологічного клімату. Через те виникає необхідність наукового аналізу психологічної атмосфери, 3 метою своєчасної профілактики та корекції негативних явищ у колективі педагогів. Серед таких явищ досить активно може розповсюджуватися i мобінг [4]. Нажаль, випадки мобінгу здатні поставити під загрозу виконання професійних завдань, що стоять перед конкретним 
педагогічним колективом, негативно вплинути на психосоматичне здоров'я його членів.

Отже, проведення ефективної роботи щодо вивчення мобінгу у педагогічному колективі потребує здійснення глибинного аналізу цього соціально-психологічного явища. Цілком очевидним $є$ те, що превентивний зміст діяльності керівника закладу вищої освіти вимагає відповідних знань, умінь та навичок. Глибинне вивчення ситуації конфлікту дозволяє керівникові отримати уточнення цілей та завдань щодо оздоровлення психологічного клімату, з'ясування причин та обставин виникнення мобінгу, здійснити аналіз результатів вивчення мобінгу, підбір оптимальних варіантів подолання мобінгу серед підлеглих. Результати нашого вивчення цієї проблеми свідчать про те, що основними завданнями керівника при діагностиці мобінгу серед підлеглих мають бути:

1. Вивчення соціально-психологічного клімату конкретної групи.

2. Виявлення ініціаторів мобінгу.

3. Виявлення жертви мобінгу.

4. Виявлення пасивних (вимушених) учасників мобінгу.

5. Виявлення психологічних, соціально-економічних передумов виникнення мобінгу у підрозділі.

6. Вивчення наслідків мобінгу для його ініціатора та жертви.

Практика свідчить, що керівник підрозділу має можливість отримати інформацуію про мобінг різними шляхами:

-до нього може звернутися безпосередньо жертва мобінгу; 
-його можуть проінформувати молодші керівники або інші підлеглі;

-його можуть проінформувати родичі жертви мобінгу;

-він може бути свідком мобінгу особисто.

Отримавши необхідну інформацію про зміст процесу мобінгу, керівник повинен без зволікань реалізувати ряд заходів щодо його подолання. 3 цією метою нами пропонується програма психологічної діагностики та подолання керівником закладу вищої освіти випадків мобінгу серед викладачів. Необхідно застосувати системний підхід, при якому діяльність керівника підрозділу має бути присвячена досягненню конкретної мети виявленню та подоланню процесу мобінгу серед підлеглих. Зважаючи на аналіз наукових джерел [2; 5], досягнення такої мети тісно пов'язано з вирішенням низки завдань, зокрема:

$$
\text { -вивчення морально-психологічного клімату у }
$$

педагогічному колективі;

-діагностика міжособистісних стосунків між членами підрозділу;

-виявлення суб'єктів та об'єктів мобінгу та стратегій їх поведінки;

-подолання явища мобінгу;

-зміцнення почуття відповідальності членів колективу за морально-психологічний клімат у підрозділі.

При розробці програми, ми враховували те, що вона повинна відображати всі аспекти роботи щодо виявлення та подолання мобінгу у колективі. Отже програма має відображати сукупність методів (способів) діагностики та подолання керівником мобінгу серед підлеглих. Наше дослідження свідчить 
про те, що превентивна функція в управлінській діяльності керівника підрозділу реалізується через постійний збір, аналіз фактів деструктивної взаємодії, об'єктивне оцінювання морально-психологічного клімату підрозділів та своєчасне проведення заходів щодо усунення проблем у міжособистісних стосунках науково-педагогічних працівників; здійснення комплексної психологічної діагностики та корекції функціональних порушень у психологічному здоров’і членів колективу.

На психологічному кліматі колективу у закладі вищої освіти позначаються також взаємини співробітників із тими, на кого вони самі впливають за характером своїх професійних обов'язків. Задоволеність педагогів стосунками зі студентами/слухачами набуває великого значення у зв'язку із демократизацією та гуманізацією освітнього процесу. Постійна якісна взаємодія «викладач -студент»- одна 3 найважливіших умов у роботі, базова мотивація до вдосконалення педагогічної майстерності, творчості. А позитивні стосунки зі студентами можуть стати (на певному етапі) компенсуючим фактором, який допомагає педагогу пережити такі негативні обставини, як складні взаємини з колегами та керівництвом, недостатня оплата праці, несприятливі життєві обставини. Професійна психологічна служба в освітньому закладі має стати центральним структурним підрозділом, що сприятиме збереженню й зміцненню соматичного, психічного здоров'я кожного члена колективу, профілактиці формування у них синдрома професійного вигорання, психологічному супроводу педагога у ситуації життєвої чи професійної кризи, покращенню соціально- 
психологічного клімату у педагогічному колективі закладу вищої освіти.

Серед рекомендацій працівникам психологічної служби щодо покращення мікроклімату можна зазначити наступні:

-Проводити систематично соціометричне чи референтометричне дослідження для аналізу стану мікроклімату колективу з метою виявлення «вогнища» проблеми.

-Проводити діагностику синдрому професійного вигорання та інформувати педагогів шодо прийомів уникнення емоційного виснаження.

•Надавати психологічну допомогу членам колективу (за запитом) щодо саморегуляції психічних процесів шляхом аутогенного тренування, індивідуальної та групової психокорекції.

-Проводити тренінгові заняття з особистісного розвитку.

-Організувати цикл тренінгових занять із розвитку психологічної культури педагогів.

- На початку навчального року проводити заняття 3 психологічної адаптації (з метою прискорення темпу включення педагогів та студентів в освітній процес).

•Виявляти співробітників, які впливають на погіршення мікроклімату та індивідуально працювати з ними над розвитком корпоративної культури, психологічної згуртованості у колективі, здатності до самоуправління, підвищення рівня здоров'язбережувальної компетентності.

-Організувати проведення інтегрованих та бінарних заходів, семінарів, тренінгів, що сприятиме підвищенню ефективності взаємодії між членами педагогічного колективу. 
Зазначимо, що усвідомлення педагогом дезадаптаційних тенденцій у професійній діяльності $€$ важливим напрямом превентивної роботи у післядипломній педагогічній освіті, що передбачає пошук способів забезпечення збереження цілісності особистості.

Пропонуємо для отримання педагогом оцінки рівня перевантаження, конкретних практичних рекомендацій щодо здійснення самозмін у професійній діяльності використовувати можливості сучасних цифрових технологій, зокрема, додатки тайм-менеджери (органайзери) для продуктивнішого управління власним часом. Серед них - Google Календар. Його функціонал дозволяє раціонально спланувати розпорядок дня пегагога, знайти час для особистого життя i закцентувати увагу на своєчасному виконанні важливої роботи (рис. 1). Календар сповіщає про необхідність здійснення конкретно запланованих дій, за потребою у ньому налаштовується повторюваність.

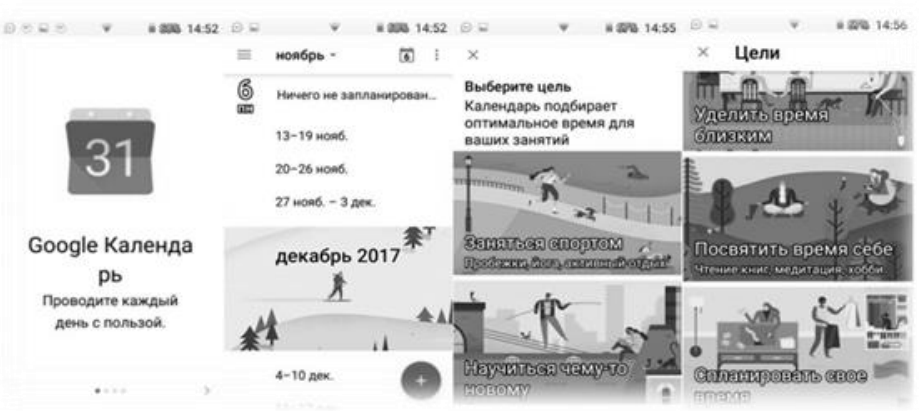

Рис. 1. Інтерфейс програми Google Календар

Водночас, можна створювати нагадування про події чи заходи професійного життя, де вказується місце проведення заходу, точний час; педагог має можливість вибрати характер оповіщення (SMS, e-mail). Планування допоможе оптимізувати власне життя для більшої продуктивності і профілактики стресів. 
Серед базових рекомендацій педагогічним працівникам необхідність максимально раціоналізувати виконання професійних дій, що сприятиме підтримці правильного життєвопрофесійного балансу, особистісному успіху.

Таким чином, необхідним для успішного професійного розвитку педагога вищої школи критерієм $є$ професійне та особистісне самозбереження, постійна рефлексія власного «Я», самоаналіз професійної діяльності, перманентне професійне та особистісне самоудосконалення й усвідомлення того, що в певні періоди професійної кар'єри він потребує допомоги фахівцяпсихолога, основним завданням якого і $є$ психологічний супровід, фасилітація успішної професіоналізації особистості.

Висновки та перспективи подальшого дослідження.У психологічному супроводі педагога щодо збереження і зміцнення його психосоматичного здоров'я, сприяння особистісному зростанню, для практичного психолога існує велике поле діяльності: просвітницька, діагностична і психокорекційна робота з метою:

-підвищення грамотності науково-педагогічних працівників із питань збереження їхнього професійного здоров'я; -попередження професійних деформацій (як загальнопедагогічних, так і типологічних);

-допомога у формуванні психологічного захисту від стресу, при потребі - у подоланні наслідків стресогенних, кризових та надзвичайних ситуацій, усуненні синдрому емоційного згорання; -профілактика педагогічних криз і допомога в усуненні їх наслідків; 
-допомога в усуненні невротичних, психотичних i психосоматичних розладів та залучення при необхідності відповідних вузьких спеціалістів-лікарів (з метою недопущення хроніфікації патологічних процесів);

-превентивна робота зі створення сприятливого психологічного клімату у педагогічному колективі, у співпраці 3 адміністрацією освітнього закладу, 3 метою створення психологічно безпечного освітнього середовища.

Психолог, що працює у закладі вищої освіти, повинен бути теоретично обізнаний щодо проявів дезадаптаційних тенденцій у діяльності педагогів, уміти розробляти комплексні психопрофілактичні програми для збереження професійного здоров’я педагогів, гармонізації їх внутрішнього світу. В арсеналі практичного психолога мають бути валідні та надійні методики для оцінки загального психічного стану, самопочуття особистості, для виявлення відхилень у психоемоційній сфері, схильності до емоційного згорання, ступеня ефективності адаптаційних механізмів у ситуації стресу. Для реалізації визначених завдань фахівець може використовувати різноманітні методи роботи: як індивідуальні, так і групові бесіди та консультації, семінари за тематикою профілактики синдрому емоційного вигорання, психологічні тренінги, психотехнічні ігри; має володіти технологіями зняття психоемоційної напруги, методами психічної саморегуляції для здійснення якісного психологічного супроводу викладачів в умовах специфічної міжособистісної взаємодії у закладах вищої та післядипломної освіти. 
Участь у тренінгах, виїзних семінарах, курсах підвищення кваліфікації, а відповідно і перехід на нову кваліфікаційну категорію або посаду (підвищення почуття відповідальності, новизна роботи) стають значущою мотивацією для подолання почуття повсякденності та емоційного вихолощення. Періодична зміна характеру діяльності, використання можливостей інформаційно-комунікаційних технологій, оновлення програми навчальної дисципліни, зміна місця проживання і роботи можуть стати ефективним засобом профілактики професійних деформацій у викладачів вищої школи. Важливого значення набуває і комплексна діяльність всієї команди професіоналів зі створення сприятливого психологічного клімату у педагогічному колективі, у тісній співпраці з адміністрацією освітнього закладу, 3 метою створення безпечного освітнього середовища, в якому реалізуються цілі та завдання всіх учасників міжособистісної взаємодії.

\section{Список використаних джерел}

1. Алберти, Р. Самоутверждающее поведение. Распрямись! Выскажись! Возрази! / Р. Алберти, М. Эммонс ; пер. с англ. М. В. Горшкова. - СПб.: «Академический проект», 1998. 190 c. c. 17.

2. Андреева Г. М. Социальная психология: учебник для высших учебных заведений. М.: Аспект Пресс, 1997. 376 с.

3. Басенко В. П., Ж Жуков Б. М., Романов А. А. Организационное поведение: современные аспекты трудовых отношений. Учебное пособие. Издательство "Академия Естествознания", М.: 2012. — 384 с. 
4. Басова А. Г. Формирование эмпатии [Текст] / А. Г. Басова // Молодой ученый. - 2013. - №5. - С. 631-633.

5. Берн Э. Трансактный анализ и психотерапия. СПб., 1992.- 224c.

6. Беспалов Ю. Ассертивность - качество Лидера, или, как быть твердым в целях, но гибким в средствах [Электронный pecypc] [Режим доступа]: http://nlp.by/about-nlp/nlp-styi-ipublikacii/215-assertive-kacestvo-lidera.

7. Степанов О. М. Психологічна енциклопедія /О. М. Степанов. - К.: "Академвидав", 2006. - 32 с.

8. Столин В. В. Самосознание личности. - М.: Изд-во МГУ, 1983. - $286 \mathrm{c}$.

9. Стрелкова, Л. П. Психологические особенности развития эмпатии у дошкольников: автореф. дис. ... канд. психол. наук: 19.00.07 / Л. П. Стрелкова; АПН СССР, НИИ дошк. воспитания. - М., 1987. - 24 с.

10. Харламенкова, Н. Е. Разработка валидной процедуры оценки самоутверждения личности / Н. Е. Харламенкова, Е. П. Никитина // Психологический журнал. - 2000. - T. 21. - № 6. - C. 67-76.

11. Хохлова, Е. В. Конструктивная агрессивность в формировании навыков ассертивного поведения студентов вуза: автореф. дисс. на соискание учен. Степени канд. психол. наук : спец. 19.00.07 “Педагогическая и возрастная психология" /Е. В. Хохлова. - Нижний Новгород, 2008. - 26 с.

12. Шамиева, В. А. Ассертивность в структуре личности субъекта адаптации: автореф. дисс. на соискание учен. степени канд. психол. наук: спец. 19.00.01 “Общая психология, история 
психологии" / В. А. Шамиева. - Хабаровск, 2009. - 207 с.

13. Шамиева, В. А. Ассертивность в структуре личности субъекта адаптации / В. А. Шамиева, К. И. Воробьева // Социально-гуманитарные науки на Дальнем Востоке: сборник статей. - Хабаровск : Изд-во ДВГУПС, 2009. - № 4. - С. 79-83.

\section{REFERENCES (TRANSLATED \& TRANSLITERATED)}

1. Alberti, R. Samoutverzhdayushhee povedenie. Raspryamis`! Vy`skazhis`! Vozrazi! [Self-affirming behavior. Straighten up! Speak out! Object!] / R. Alberti, M. E`mmons ; per. s angl. M. V. Gorshkova. - SPb.: «Akademicheskij proekt», 1998. - 190 s. s.17. [In Russian]

2. Andreeva G. M. Soczial naya psikhologiya: uchebnik dlya vy`sshikh uchebny`kh zavedenij [Social Psychology: A Textbook for Higher Education]. M.: Aspekt Press, 1997. 376 s. [In Russian]

3. Basenko V.P., Zhukov B.M. , Romanov A.A. Organizaczionnoe povedenie: sovremenny`e aspekty` trudovy`kh otnoshenij [Organizational behavior: modern aspects of labor relations. Tutorial]. Uchebnoe posobie. Izdatel`stvo "Akademiya Estestvoznaniya", M.: 2012. - 384 s. [In Russian]

4. Basova A. G. Formirovanie e’mpatii [Empathy Formation] / A. G. Basova // Molodoj ucheny`j. 2013. \#5. S. 631-633. [In Russian]

5. Bern E`. Transaktny j analiz i psikhoterapiya [Transactional Analysis and Psychotherapy]. SPb., 1992.- 224s. [In Russian]

6. Bespalov Yu. Assertivnost - kachestvo Lidera, ili, kak by ' $t$ ' tverdy` $m \mathrm{v}$ czelyakh, no gibkim $\mathrm{v}$ sredstvakh [Assertiveness is 
the quality of the Leader, or how to be firm in goals, but flexible in means] [E`lektronny`j resurs] [Rezhim dostupa]: http://nlp.by/aboutnlp/nlp-styi-i-publikacii/215-assertive-kacestvo-lidera. [In Russian]

7. Stepanov O.M. Psikhologi`chna encziklopedi ya [Psychological Encyclopedia] /O.M. Stepanov. - K.: "Akademvidav", 2006. - 32 s. [In Russian]

8. Stolin V. V. Samosoznanie lichnosti [Self identity of the personality]. - M.: Izd-vo MGU, 1983. - 286 s. [In Russian]

9. Strelkova, L.P. Psikhologicheskie osobennosti razvitiya e`mpatii u doshkol`nikov [Psychological features of the development of empathy in preschool children]: avtoref. dis. ... kand. psikhol. nauk: 19.00.07 / L.P. Strelkova; APN SSSR, NII doshk. vospitaniya. M., 1987. - 24 s. [In Russian]

10. Kharlamenkova, N. E. Razrabotka validnoj proczedury oczenki samoutverzhdeniya lichnosti [Development of a valid procedure for assessing self-identity] / N. E. Kharlamenkova, E. P. Nikitina // Psikhologicheskij zhurnal. - 2000. - T. 21. - \# 6. - S. 6776. [In Russian]

11. Khokhlova, E. V. Konstruktivnaya agressivnost' v formirovanii navy`kov assertivnogo povedeniya studentov vuza [Constructive aggressiveness in the formation of assertive behavior skills of university students] : avtoref. diss. na soiskanie uchen. Stepeni kand. psikhol. nauk : specz. 19.00.07 "Pedagogicheskaya i vozrastnaya psikhologiya" /E. V. Khokhlova. - Nizhnij Novgorod, 2008. - 26 s. [In Russian]

12. Shamieva, V. A. Assertivnost' v strukture lichnosti sub`ekta adaptaczii [Assertiveness in the personality structure of the subject of adaptation]: avtoref. diss. na soiskanie uchen. stepeni kand. 
psikhol. nauk: specz. 19.00.01 "Obshhaya psikhologiya, istoriya psikhologii" / V. A. Shamieva. - Khabarovsk, 2009. - 207 s. [In Russian]

13. Shamieva, V. A. Assertivnost' v strukture lichnosti sub`ekta adaptaczii /V. A. Shamieva, K. I. Vorob`eva [Assertiveness in the personality structure of the subject of adaptation] // Soczial nogumanitarny`e nauki na Dal`nem Vostoke: sbornik statej. Khabarovsk: Izd-vo DVGUPS, 2009. - \# 4. - S. 79-83. [In Russian

C NDSAN (MFC - coordinator of the NDSAN), Italy, 2019 


\title{
POLY-SYSTEMIC INTEGRITY OF THE PERSONALITY
}

\author{
Evheniia Geyko \\ Volodymyr Vynnychenko Central Ukrainian State Pedagogical University, Ukraine
}

\begin{abstract}
An attempt to reveal theoretical and analytical phenomenology of the personality integrity has been made in the article. The systemic approach determines the poly-systemic structure of the personality integrity. Applying the principle of systemacy to the reflection of psychological nature of the personality integrity, the components of the structure of integrity in interconnection and interdependence are considered. The specificity of the object and subject of the study, which influence the content of the personality integrity, is determined.
\end{abstract}

Keywords: systemic approach, poly-systemic integrity of the personality, integrity, personality integrity

Formulation of the problem. In the current context of reforming education in Ukraine, the problem of the development and formation of the personality integrity appears. However, the very concept of "personality integrity" needs clarification. Revelation of the psychological nature of this phenomenon makes it possible, in fact, systematic approach, which allows exposing the hierarchical complexity and interconnectedness of the structural components of this phenomenon.

Thus, the personality integrity is the unity of worldview orientations, which is manifested in the autonomy of the individual, responsibility for his actions, reflexivity, openness, ability for self-development and self-realization. The opposite of "integral personality" is "fragmentary personality" - personality, whose structural components conflict with each other and do not represent integral picture of the world.

Analysis of relevant scientific researches and publications. The systemic approach involves obligatory analysis of the system structure (psyche, personality). At the same time, it is special open feedback system. Thus, as noted by M. Savchin: "At each level of determination, it is included in the regulation of the subject interaction with broader biological system (at the level of the 
organism), the social system (at the level of the individual), created by cultural and historical values of the society and the physical world (at the level of the personality) and the spiritual sphere (at the level of the immateriality)" [7].

The further development of the systemic approach is considered to be integration of age, psychological and subjective. As noted by M. Yermolaieva, D. Lubovskyi, attempts of holistic description of human development along the life path are characterized by paradigmatic changes, namely: psychology of childhood is primarily represented in the theoretical views of L. Vyhotskyi, O. Leontiev, D. Elkonin, however, youth often appears with the historical and sociological study of the life path, developed in the works of I.Kohn, and maturity, aging - with the subjective approach of S. Rubinstein, B. Ananiev [5].

Within this approach it is possible to consider the activity of the subject in terms of its own development. This allowed us to introduce into the psychological science the concepts of "self-development", "self-realization", and "selfdetermination", aimed at identifying the origins of human mental development. However, this approach is implemented in the adult learning process because it cannot be understood differently than self-development.

Thus, M. Yeromolaiev and D. Lubovskyi emphasize that the importance of combining two approaches within systemic one is due to the fact that it is impossible to fully disclose the development of adult in his/her integrity, the specificity of his/her self-development without representing driving forces, the mechanisms of this process, which go back to childhood [5, p. 105].

In other respects, it is worth noting that the integration or implementation of systemic-integral approach contributes to the representation of the psychological nature of the personality integrity. However, based on the interconnectedness of the elements, internal correlation and hierarchy of components or elements of the system, it is right to use the term "poly-system", and accordingly, it's worth considering strictly "poly-systemic integrity of the personality". Such perspective is insufficiently researched in modern psychological science.

Thus, the purpose of our article is to reveal features of the personality integrity as essential prerequisites for its self-realization from systemic approach point of view, which helps to identify the most essential features of this phenomenon, as well as to determine its poly-systemic structural organization. 
Presenting main material. Embodying the concept of "the integrity" actually within systematic approach, S. Maksimenko considers integrity as meaningful (key) sign of the personality. Characterizing the personality as formation consisting of individual mental phenomena (processes, states, properties), the scientist insists that the personality is not the sum of these phenomena, is not "adding conceptions" of its individual components, simultaneously, integrity of the personality is not determined by the sum of its components. Even each component does not exist separately, independently. "It is the bearer of the whole personality, as well as his/her imprint. Personality lives, develops and formes only collectively, as integrity", as S. Maksimenko notes [6].

Afterwards, the researcher focuses on the "living movement of the integrity", that is, emphasizes the constant development, dynamics, and change of the integrity itself as a sign of personality. In this way, we can observe the interconnections of the integrity components, their alterations, and, consequently, the personality as a whole. However, the author notes that such changes are secondary and even tertiary compared to the whole - the personality. "They appear after separate live movement of the personality and contribute to subsequent integral movements". Such ability of the personality as integrity becomes apparent in the reflection of both at the level of the particular trait (component of the integrity) and at the level of the personality.

According to the principle of the personality integrity concept by $\mathrm{S}$. Maksimenko, the personality must exist as a whole, and its own integrity is expression and essential feature of the personality. "Thus, the personality integrity specifically covers all structural and dynamic manifestations of human life. It is caused not by the sum of individual components, but by the integrated unity of three origins of the individual existence - biological, social and spiritual". However, the scientist notes that it is impossible to consider integrity as an attribute trait of the personality. Because such integrity is unique in each individual, something similar to others, but still, significantly different.

The problem of the psychological nature of integrity is closely linked to the personality immateriality. M. Savchin even introduces the concept of "integral vital activity" into psychology. Therefore, "according to the spiritual paradigm, the personality and mentality should be considered in the context of integral vital 
activity, the main content of which is its (human being) self-perfection as the image of God, directed toward the likeness of God, and the world perfection (creation of love, good) as the Kingdom of God on earth"[7].

The scientist also insists on considering the personality integrity in the context of leading principles of psychological science: "the subject integrity is the basis of systemic connections of all its psychic qualities, often contradictory, difficult-to-integrate, and above all, it means unity, integrity of its activity and development". Thinking over the personality nature, the scientist notes that "individual subject is defined on the basis of its unique contribution to the common, integral activity, participation in its design, construction and development". This is actually the principal criterion for self-development of individual subject, person who is at the highest level of activity, integrity (systemacy), autonomy. In addition, the author notes that the appointed level is individualized for each individual or group of people, taking into account motivation, abilities, intelligence, will, real historical conditions.

A person is not born a subject, but becomes it, separating him/herself from surroundings and opposing him/herself as an object of action, cognition, contemplation. In the course of activity, reality appears to the subject not only as system of irritants with which he interacts at the reaction level, but also as object, and other people - also as subjects.

Let us appeal to the concept of "the personality integrity" in the conception of the personality proposed by T. Tytarenko. The scientist, in particular, believes that introduction of the category "the life-world", ensures the true integrity of man and the world, makes it possible to study the psychological reality within which every human life develops [8].

Within his own conception of the personality, T. Titarenko distinguishes individual variants of the psychological spaciousness as well as the concept of "the personality integrity".

It is worth noting that the concept of "psychological spaciousness of the personality life-world" is characterized by the following properties:

- the availability of poles - good and evil, positive and negative. There is constant interaction between these poles, that creates, depending on the advancement of the individual to the pole, personal potential, stimulating personal 
growth, or, conversely, neurotic protection, aggressive manifestations, frustrating reactions that cause panic, fear or shame.

Considering the principles of systemic-integral approach, it should be pointed out that the personality integrity (as a system) consists of many basic interrelated, interdependent elements. The problem of criteria for determining the basic elements, their specificity and peculiarities of manifestation is the most complex and hardly covered in scientific researches. The issue of complexation of the personality integrity with regard to its differentiation remains underdeveloped.

Considering this concept of the personality integrity, the personality and the world are simultaneously integral and independent systems. The personality component has biochemical, physiological, somatic properties. The world component has the same qualities, but when another person appears, the physical, mechanical, and other properties are added if things and objects appear as the world. The integrity is thus separated and its components discrete.

Systems are somewhat other than components, supercomposite, and extrasensory formations. The personality integrity (as a system) is the sphere of functions that overlaps the components of the individual and the world. The personality as a system differentiates itself from the personality as a component, crosses its physical limits and assimilates the world. In the personality (as a system), the individual plays the role of system-forming quality, and its world the role of controlled subsystem. In turn, the world (as a system) is the sphere of functions that overlaps the components of the world and the personality. The world as a system stands out from the world as a component, goes beyond its physical limits and engages the personality. In the world as a system, the role of the system-forming quality is fulfilled, and the personality - the role of the managed system.

The personality (as a system and the world) as a system is differentiated, but also interacts. One of the effects of their interaction is expansion. Personality enters the world and the personality system expands; the world enters the personality and the world system expands. The world ( as a subsystem of personality), and personality (as a subsystem of the world) are the results of extensions and interactions of the personality and the world.

In the concept of the personality integrity (as a system) the concept of interaction extends to the personality, world and activity. According to indicated 
concept, the integral world appears as poly-system and obeys the principle of the duality of qualitative certainty: the personality and the world interact as systems and subsystems of each other. It is important that several forms of activity give nature of active polyphony to the personality and the world interactions.

Thus, the integral world is organized into poly-system through the interaction of the personality and his/her world in two positions: independent systems and subsystems of each other. The poly-systemic interactions of the personality and his/her world are divided into different components. The interactions are localized in the field of the personality component and in the field of the world component. The position (system or subsystem), localization (in the component of the personality and the world) and interaction (taking into account position and localization) are the key parameters of integral world. They give it variety, diversity, relativity.

Depending on position, (localization and interaction) the four spheres of the integral world are distinquished. In the first sphere (in the field of the personality component) systemic quality of the individual is localized. This is the sphere of the "Personality" system. In it, the "Personality"as a system does not interact with the world as a system. In the second sphere (poly-component of the world) the systemic quality of the world is localized. This is the sphere of the "World" system. In it, the"World", as a system, interacts with the personality as a subsystem.

It is the systemic approach that draws attention to the personality integrity. In the cognitive model of the personality integrity, as a device for dynamic information processing, exclusively systemic issues are considered: integration, fragmentation, multidimensionality, hierarchy. At the same time, the cognitive paradigm exerts certain influence on the understanding of the personality integrity. However, consideration only from the point of view of the mechanism of information processing leads to the fact that the phenomenon of the personality integrity loses its own nature and specificity. Separation of subsystems in integrities (cognitive-affective-performing and interpersonal, cognitive, emotional) is logical for the Connectionist model.

The personality integrity study in the unity of its differentiation and integration within systemic approach is important. It is the concept of the personality integrity that can serve as such a basis. Such concept makes it possible 
to systematically imagine the personality integrity as poly-system, to identify modalities, submodalities and dispositions as its various aspects.

From the position of systemic-integral approach, the personality integrity is defined in this way: the mental representation of the integral world to individual. Mental representations are diverse, interpersonal, positional; which are subject to change.

For determination of systemic-integral approach, the term "poly-systemic personality integrity" should be used, which is similar in meaning to the concept of "poly-modality", which was introduced by L. Dorfman [4]. Poli-modality is based on the principles of the personality "Self-concept", developed by J. Kihlstrom, L. Foster, S. Klein and refined by L. Dorfman in his concept of the meta-individual world. So, the "Self-concept" appears in the form of mental representation of the person's particularities of his/her meta-individual world.

However, the poly-system is characterized by the duality of qualitative certainty and relativity. The duality has manifestation: stability and variability, coherence and inconsistency, rationality and irrationality, ability to plan and automatism, initiativeness and rigidity.

In L. Dorfman's researches the general properties of poly-modality are defined, attention is focused on submodalities, along which systems, modalities and dispositions were considered [4, p. 96 - 157].

Conclusions and prospects for further researches. Thusly, the integrity is the proper interrelation of the elements, the internal correlation and correspondence, the hierarchy of components or elements of the system. The integrity is related to the hierarchy of structures. However, the hierarchy of structures is considered common feature of integrity. Also, each integrity component, in turn, has its own structure. The organization of integrity is the consentaneity of the structural formations of parts in general structure.

The integrity is determined by the totality of the system's internal and external relationships, connections and interactions. The internal and external connections of the integral system are in some way consistent (harmonized) with each other. During the formation and existence of integrity, there is always discrepancy between the external and internal connections of the system. Therefore, the integrity of the system is not so much the result of its previous development, but the ability to maintain such state in the process of constant 
movement, change and development. Thus, the integrity of the system is both prerequisite and result of itself.

Apart from this, of great importance is the fact that the integrity of the system is not only the correspondence of the elements, the integrals of a body, but also the connection of each element with the whole. The interaction of part, element, whole is characterized by interference. During the interaction of the part and the whole, when the part can represent the whole and the whole penetrates into the parts, this is the way of developing the part and the whole, improving the structure of the system as a whole and its individual components. The leading action in this complex process belongs to the structure of the whole; that is the whole that determines its own progress through the development of the parts.

As leading factors, it is advisable to identify systemic concepts of isomerism, multidimensionality, hierarchy. Isomerism is considered as a mechanism of communication, of transitions from one component of multimodal personality integrity to another. Multidimensionality should be revealed as multiaspectuality of the poly-systemic integrity of the personality. The hierarchy must be reflected through the "vertical" and "horizontal" in the structure of the multimodal personality integrity. So, the "vertical" structure is Holon, special form of correlation of the whole and parts.

Suchwise, the personality integrity is revealed through the agreed structural elements (systems, modalities, dispositions) in the general structure on the principle of poly-system. Poly-systemic personality integrity is the corresponding interconnectedness of elements, internal correlation and hierarchy of components or system elements.

The research prospect is to study the peculiarities of poly-systemic personality integrity formation in ontogeny from the position of systemic-integral approach.

\section{References:}

Ball, G. O. (1998). Problema obhruntuvannia suspilnoii ideolohiii u svitli humanistichnoho pidhodu [The problem of justification of social ideology in the light of a humanistic approach] / G. O. Ball // Psiholohopedahohichna nauka i suspilna ideolohiya: Materiali metodolohichnoho 
seminaru Akademii pedahohichnyh nauk Ukrainy, 12 lystopada 1998 r. [Psychological and Pedagogical Science and Social Ideology: Materials of the Methodological Seminar of the Academy of Pedagogical Sciences of Ukraine] Kyiv. Gnozis. S. 28 - 32. [in Ukrainian].

Bertalanfi, L.(1960). Obschaya teoriya sistem [General theory of systems] / L. fon Bertalanfi. Moscow. Mir. 328 s. [in Russian].

Vyhotskii, L. S. (2005). Psiholohiya razvitiia cheloveka [Psychology of human development] / L. S. Vyihotskii. Moscow. Smysl; Eksmo. 1136 s. [in Russian].

Dorfman, L. Ya. (2004). Ya-kontseptsiia: differentsiatsiia i intehratsiia [Iconcept: differentiation and integration] / L. Ya. Dorfman. // Intehralnaia individualnost, Ya-kontseptsiia, lichnost [Integral personality, I-concept, personality] / Pod red. L. Ya. Dorfmana. Moscow. Smysl. S. 96 - 123. [in Russian].

Yermolaieva, M. V. (2012). Teoretyko-metodolohicheskii analiz razvitiia vnutrennei pozitsii lichnosti na protiazhenii zhiznennoho puti (integratsiia vozrastno-psihologicheskoho $i$ sub'ektnoho podhodov) [Theoretical and methodological analysis of the development of the internal position of the person throughout the life (integration of agepsychological and subjective approaches)] / M. V. Yermolaieva, D. V. Lubovskii // Mir psiholohii. 3 (71). S. 104 - 113. [in Russian].

Maksymenko, S. D. (2007) Struktura osobystosti [The structure of the person] // Prakt. psyholohiia ta sots. robota. № 1. S. 1 - 13. [in Ukrainian].

Savchin, M. (2011). Doslidzhennia osobystosti v konteksti duhovnoii paradigmy psyholohii [Investigation of personality in the context of the spiritual paradigm of psychology] // Psyholohiia osobystosti, No 1 (2). S. 191 199. [in Ukrainian].

Tytarenko, T. M. (2003). Zhyttievyi svit osobystosti: u mezhakh $i$ za mezhamy budennosti [The vital world of personality: within and beyond the ordinary] / T. M. Tytarenko. Kyiv: DP Spetsializovane vydavnytstvo «Lybid». 376 s. [in Ukrainian] 


\title{
Subjective well-being in late adulthood: the views of elderly people and younger generation
}

\author{
Iryna Kryvenko \\ Ukrainian Catholic University, Lviv, Ukraine
}

\begin{abstract}
Introduction. Like sex or skin colour, age stratification usually becomes a background for prejudices and discrimination. Common stereotypes depict old age as a time of poor health and functioning, a regression back to childhood (Ory et al., 2003, p.165), financial limitations, social surrounding and lifestyle changes etc. Although these are mostly myths, elderly people usually internalize them. In fact, even in the USA, less than $12 \%$ of the old-aged people declare experiencing a "successful ageing", the rest claim that health problems, cognitive limitations, social isolation, inability to spend time interestingly are the factors making them unhappy (McLaughlin et al., 2010).
\end{abstract}

Some of the age stereotypes are produced by elderly people themselves (Schmidt, Boland, 1986). However, comparing to younger generations' views of this life period, they are more diverse and complex, while youth describe ageing in more simple and dogmatic way. Giving some positive descriptions of elderly people (stressing on their wisdom, good communication with children (Hummert et al., 1994), spirituality (Kornadt, Rothermund, 2012)), they also associate them with many negative sides, mainly in the spheres of relationships with friends, financial aspects, physical and mental health (Kornadt, Rothermund, 2012). The mismatches in views of ageing among elderly and younger people may produce the feeling of misunderstanding, rejection, unhappiness among pensioners. Numerous researches have proved the influence of age stereotypes on elderly people's physical health, cognitive abilities, self-attitude (Levy, Slade, Kasl, 2002, Ory et al., 2003, Dionigi, 2015). However, most of them are made in Western societies, and as stereotypes and prejudices are social phenomena, they strongly depend on the conditions they appeared in. Thus, it is important to find out some specific view of late adulthood among Ukrainians. This study focuses mainly on the conceptions of happiness in late adulthood among elderly people and younger generation.

Purpose. The aim of this research was to find out the differences in subjective well-being concepts of elderly people among younger and older respondents.

Design. To reach this aim, two studies were conducted. For Study 1, the group of elderly people $(\mathrm{N}=260 ; 81$ males, 179 females; age 60-88, Mean $=72.9, \mathrm{SD}=$ 7.8) was asked to fill in the questionnaires on different aspects of subjective wellbeing (Satisfaction With Life Scale by Diener et al. (1985) and Affective Balance Scale by Bradburn (1969)). In Study 2 ( $\mathrm{N}=205$; 60 males, 145 females; age 1756 , Mean $=24.4, \mathrm{SD}=4.5)$ there were two younger people groups. Group $1((\mathrm{~N}=$ 116) were those who closely interact with someone who is at the late adulthood period at the time of research (also matching the quality of the relationships from 1 to 10 , the bigger the better), Group $2((\mathrm{~N}=89)$ were those who did not. Both groups received the same questionnaires, with the task to answer the questions as they think their close elderly person (Group 1) or "the average elderly person" (Group 2) would respond. 
Results. Subjective well-being is a complex phenomenon, but most of the researchers agree in consists of two main components which are cognitive, or contentment, life satisfaction, and affective, or emotional balance, the amount and intensity of positive and negative affects (Diener, Oishi, \& Lucas, 2003). On the results of comparative analysis with Mann-Whitney criterion, there was a significant difference in elderly people's and younger respondents' views of life satisfaction in late adulthood $(\mathrm{p}<.05)$. Namely, youth think that old-aged people are more satisfied with what they have in lives than those people really declare. Probably this may be explained by not understanding well all the difficulties that elderly people are facing in their lives by the younger generation. What is also meaningful is that the fact of close communication with the elderly people does not influence this result.

On the other hand, elderly people state that they experience both positive and negative emotions $(\mathrm{p}<.05)$ more often than youth think which means that younger people underestimate the intensity of elderly people's affects. Maybe, the view of older people as balanced and restrained is connected with the real improvement of emotional control in late adulthood (Charles \& Carstensen, 2007). However, this may also be explained by the stereotype of wan and monotonous life of the elderly people which gives no reason for deep emotions.

Surprisingly, respondents of the Study 2 who do not have close relationships with elderly people were closer to the older people's results than Group 1 ( $p<.05)$. Probably, communication helps to create more positive image of late adulthood. This also may explain the fact that elderly people who live with someone of their family or relatives feel happier: they get not only support in these relationships but also maintain positive self-image. However, the quality of the relationships is an important factor here. On the results of the Spearman rank correlation analysis, positive links between this measure and life satisfaction $(r=.24)$ and affective balance $(\mathrm{r}=.42)$ were found.

Limitations. Certain limitations of the current research should be noted. The future study should pay more attention to socio-demographic variables and its influence on the subjective well-being of elderly people and youth views. E.g., the comparative analysis of different age groups in the youth sample could be done if the number of respondents in each age group was comparable enough. For further research it would be more fruitful to add some qualitative not only quantitative methods of collecting data for deeper understanding of age stereotypes. Finally, some personality variables that may influence the level of subjective well-being components need to be controlled.

Practical value. The received results may be used for rethinking of the educational system in cases of teaching generations to understand each other better. Namely, showing the differences in youth and elderly people's views of life in late adulthood could be a good opportunity for building new, more realistic view of older people's lives among youth. Enclosing the differences in views may also be a good method for fighting against ageism. Moreover, this also may help to lower the level of fears of becoming old which usually appear in different younger cohorts, so the results may be used in psychological counseling.

Conclusions. The research demonstrated some differences in elderly people's subjective well-being and the views of happiness in late adulthood among younger generation. Generally, ageing is associated with some limitations which are not usually felt by old-aged people. On the other hand, some of the difficulties 
of their age may be underestimated. Younger people tend to think that elderly people lived good life which is mostly close to what they dreamed about, received what they wanted; thus, youth build a cognitively positive view of life. However, youth evaluate elderly people's emotional attitudes towards life as less intense than old-aged people do, not necessarily positive or negative but not really filled with deep feelings. Elderly people themselves, instead, do not feel being so wellregulated emotionally and stress on much more intense positive and negative affects in their life evaluation.

Keywords: elderly people, younger generation, youth, stereotype, subjective well-being.

\section{References:}

1. Bradburn, N. M. (1969). The structure of psychological well-being. Chicago: Aldine.

2. Charles, S.T., \& Carstensen, L.L. (2007). Emotion Regulation and Aging. In J.J. Gross (Ed.), Handbook of emotion regulation. New York, NY, US: The Guilford Press, 307-327.

3. Diener, E., Emmons, R. A., Larsen, R. J., \& Griffin, S. (1985). The Satisfaction with Life Scale. Journal of Personality Assessment, 49, 71-75.

4. Diener, E., Oishi, S., \& Lucas, R. E. (2003). Personality, culture, and subjective well-being: Emotional and cognitive evaluations of life. Annual Review of Psychology, 54, 403-425.

5. Dionigi, R.A. (2015). Stereotypes of Aging: Their Effects on the Health of Older Adults. Journal of Geriatrics, 2015. Retrieved from: https://www.hindawi.com/journals/jger/2015/954027/.

6. Hummert, M., Garstka, T., Shaner, J., \& Strahm, S. (1994). Stereotypes of the elderly held by young, middle-aged, and elderly adults. Journal of Gerontology: Psychological Sciences, 49, 240-249.

7. Kornadt, A., \& Rothermund, K. (2012). Internalization of age stereotypes into the self-concept via future self-views : A general model and domain-specific differences. Psychology and Aging, 27 (1), 164-172.

8. Levy, B.R., Slade, M.D., \& Kasl, S.V. (2002). Longitudinal benefit of positive self-perceptions of aging on functional health. Journal of Gerontology: Psychological Sciences \& Social Sciences, 57, 409-417.

9. McLaughlin S., Connell, C., Heeringa, S.G., Li, L.W., \& Roberts, J.S. (2010). Successful aging in the United States: prevalence estimates from a national sample of older adults. Journal of Gerontology, Series A, Biological Sciences and Medical Sciences, 65B (2), 216-226.

10. Ory, M., Hoffman, M. K., Hawkins, M., Sanner, B., \& Mockenhaupt, R. (2003). Challenging aging stereotypes: strategies for creating a more active society. American Journal of Preventive Medicine, 25/2, 3, 164-171.

11. Schmidt, D., \& Boland, S. (1986). Structure of perceptions of older adults: evidence for multiple stereotypes. Psychological Aging, 1 (3), 255-260. 